\title{
A Review on Cs-Based Pb-Free Double Halide Perovskites: From Theoretical and Experimental Studies to Doping and Applications
}

\author{
Fatemeh Heidari Gourji * and Dhayalan Velauthapillai *(D)
}

Citation: Heidari Gourji, F.;

Velauthapillai, D. A Review on Cs-Based Pb-Free Double Halide Perovskites: From Theoretical and Experimental Studies to Doping and Applications. Molecules 2021, 26, 2010. https://doi.org/10.3390/

molecules 26072010

Academic Editor: Marco Anni

Received: 3 March 2021

Accepted: 25 March 2021

Published: 1 April 2021

Publisher's Note: MDPI stays neutral with regard to jurisdictional claims in published maps and institutional affiliations.

Copyright: (c) 2021 by the authors. Licensee MDPI, Basel, Switzerland. This article is an open access article distributed under the terms and conditions of the Creative Commons Attribution (CC BY) license (https:// creativecommons.org/licenses/by/ $4.0 /)$.
Department of Computer Science, Electrical Engineering and Mathematical Sciences, Western Norway University of Applied Sciences, Inndalsveien 28, 5063 Bergen, Norway

* Correspondence: fatemeh.heidari.gourji@hvl.no or fhgo@hvl.no (F.H.G.);

Dhayalan.Velauthapillai@hvl.no (D.V.); Tel.: +47-5558-7591 (F.H.G.); +47-5558-7711 (D.V.)

\begin{abstract}
Despite the progressive enhancement in the flexibility of Pb-based perovskites for optoelectronic applications, regrettably, they are facing two main challenges; (1) instability, which originates from using organic components in the perovskite structure, and (2) toxicity due to $\mathrm{Pb}$. Therefore, new, stable non-toxic perovskite materials are demanded to overcome these drawbacks. The research community has been working on a wide variety of $\mathrm{Pb}$-free perovskites with different molecular formulas and dimensionality. A variety of $\mathrm{Pb}$-free halide double perovskites have been widely explored by different research groups in search for stable, non-toxic double perovskite material. Especially, Cs-based $\mathrm{Pb}$-free halide double perovskite has been in focus recently. Herein, we present a review of theoretical and experimental research on $\mathrm{Cs}$-based $\mathrm{Pb}$-free double halide perovskites of structural formulas $\mathrm{Cs}_{2} \mathrm{M}^{+} \mathrm{M}^{3+}$ X6 $\left(\mathrm{M}^{+}=\mathrm{Ag}^{+}, \mathrm{Na}^{+}, \mathrm{In}^{+}\right.$etc.; $\left.\mathrm{M}^{3+}=\mathrm{Bi}^{3+}, \mathrm{In}^{3+}, \mathrm{Sb}^{3+} ; \mathrm{X}=\mathrm{Cl}^{-}, \mathrm{Br}^{-}, \mathrm{I}^{-}\right)$ and $\mathrm{Cs}_{2} \mathrm{M}^{4+} \mathrm{X}_{6}\left(\mathrm{M}^{4+}=\mathrm{Ti}^{4+}, \mathrm{Sn}^{4+}, \mathrm{Au}^{4+}\right.$ etc. $)$. We also present the challenges faced by these perovskite compounds and their current applications especially in photovoltaics alongside the effect of metal dopants on their performance.
\end{abstract}

Keywords: Cs-based $\mathrm{Pb}$-free double halide perovskites; applications of double halide perovskites; doping

\section{Introduction}

During the last ten years, $\mathrm{Pb}$-based perovskites as a promising subcategory of solar cell materials have attracted intense attention of the research community due to their unique advantages. In 2009, for the first time, Miyasaka et al. published a paper demonstrating the use of methylammonium lead triiodide $\left(\mathrm{CH}_{3} \mathrm{NH}_{3} \mathrm{PbI}_{3}\right)$ as a light absorber instead of dye in dye sensitized solar cells (DSSCs) with an efficiency of 3.8\% [1]. A few years after, a solid hole transporting layer named Spiro-MeOTAD replaced the liquid electrolyte in these structures which helped to increase the efficiency of perovskite solar cells (PSCs) to $9.7 \%$ [2]. Since then, the number of research articles in this field exponentially increased, and considerable advances in power conversion efficiency exceeding $25.2 \%$ are reported for PSCs [3].

The general formula of perovskite is $\mathrm{ABX}_{3}$ where $\mathrm{A}$ is a monovalent cation (methylammonium $\left(\mathrm{MA}^{+}\right)$, formamidinium $\left(\mathrm{FA}^{+}\right)$, or $\left.\mathrm{Cs}^{+}\right), \mathrm{B}$ is a divalent metal $\left(\mathrm{Pb}^{2+}\right)$ and $\mathrm{X}$ is halide anion $\left(\mathrm{I}^{-}, \mathrm{Br}^{-}\right.$, and $\mathrm{Cl}^{-}$) [4]. Depending on A-cation, perovskites can be categorized into (1) organic-inorganic hybrid or (2) all-inorganic halide perovskite [5]. Possession of unique advantages including high extinction coefficient [6,7], low exciton binding energy [8], and tunable bandgap [9], turn the metal halide perovskites as superb carrier transporters and photo absorbers. It is noteworthy that these materials are also used not only in PSCs, but also in other optoelectronic devices, such as light-emitting diodes (LEDs) [10], lasers [11], photodetectors [12,13], and X-ray detectors [14]. 
However, there are few drawbacks regarding $\mathrm{Pb}$-based halide perovskites as an active layer in PV applications, which must be tackled in order to achieve full scale application [15]. The first concern is of lead in perovskite materials as $\mathrm{Pb}$ is a well-known heavy metal [16]. Exposure to lead causes a detrimental effect on humans and surprisingly the absorptions of this metal in children's body is four to five times larger than an adult's human body [17]. Acute exposure to $\mathrm{Pb}$ can result in kidney damages, brain damages, and gastrointestinal disease, and chronic exposure to lead may induce adverse effects on the blood pressure, kidneys, central nervous system, and vitamin $\mathrm{D}$ metabolism [18,19]. Pb also can replace Calcium and interact with proteins and, as a result, disrupts the neurotransmitter release and bone mineral density $[17,19]$. In order to decrease the usage amount of hazardous materials, including $\mathrm{Pb}$ in electronic and electric devices, different restrictions of hazardous substances (RoHS) policies were implemented in many countries with the aim of reducing the risk to both human health and environment $[17,20]$.

The second challenge with organic-inorganic PSCs is the weak operational stability of organic lead halide perovskite due to organic formamidinium $\left(\mathrm{FA}^{+}\right)$or methylammonium $\left(\mathrm{MA}^{+}\right)$which make them vulnerable to degradation upon exposure to light, high temperature and humidity [21,22].

Accordingly, in order to achieve more stable and non/less toxic PSCs, different strategies have been adopted including (1) utilization of a protective layer around perovskite material as well as resilience development of perovskite layer [23], (2) using mixed halide anions and mixed A- cations [24,25], (3) applying of additives and doping agents [25-27] such as monovalent $\left(\mathrm{Cu}^{+}[28], \mathrm{Ag}^{+}[28,29], \mathrm{Na}^{+}[28,30]\right.$, etc. $)$, divalent $\left(\mathrm{Mn}^{2+}\right.$ [30], $\mathrm{Sr}^{2+}[31]$, $\mathrm{Zn}^{2+}$ [32], etc.) and trivalent metal ions ( $\mathrm{Bi}^{3+}$ [33] and $\mathrm{Sb}^{3+}$ [34]), and (4) synthesis of 2D halide perovskites [35-37]. However, these approaches were not able to overcome the aforementioned challenges adequately. Therefore, new designs of perovskite materials, applicable to all optoelectronic devices, have been suggested through theoretical and experimental studies by different research groups where $\mathrm{Pb}^{2+}$ and $\mathrm{MA}^{+} / \mathrm{FA}^{+}$were replaced by less/non-toxic inorganic components.

In a number of studies, it has been shown that incorporation of $\mathrm{Cs}^{+}$instead of applying $\mathrm{MA}^{+} / \mathrm{FA}^{+}$in perovskite structure has led to a broad band of advantages, including decreasing crystallization temperature, enhancing the absorption before and after annealing, decreasing the side phases, improving photogenerated carrier lifetime, and reducing the density of trap states, etc., which has resulted in higher PCEs for the PSCs and has also led to better stability of perovskite structure [38]. In order to tackle the toxicity issue, $\mathrm{Sn}^{2+}$ and $\mathrm{Ge}^{2+}$ ions have been suggested as the first logical substitution of $\mathrm{Pb}^{2+}$ in perovskite structure since these metal ions have similar electronic configuration of $s^{2} p^{2}$ and thereby similar chemical properties [39-41]. It is shown that Sn-based perovskites provide numerous advantages such as narrower bandgap [42], higher charge carrier mobilities [42], and longer diffusion length [43] compared to their $\mathrm{Pb}$ analogs. But the idea of using these ions did not meet the expected results because $\mathrm{Sn}^{2+}$ and $\mathrm{Ge}^{2+}$ ions tend to be oxidized to their stable oxidations state of $4+[44] . \mathrm{Bi}^{3+}$ and $\mathrm{Sb}^{3+}$ with similar isoelectronic structure were the other explored alternatives to $\mathrm{Pb}^{2+}$ ion $[41,45]$. However, their chemical bonding preference and their 3+ oxidation state make them suitable for fitting in tetragonal structure in $\mathrm{A}_{3} \mathrm{M}_{2} \mathrm{I}_{9}$ perovskite, meaning that they have a low-dimensional structure (2D) causing poor performance [5,45-47].

Double perovskite crystals with a general formula $A_{2} M^{+} M^{3+} X_{6}$ and $A_{2} M^{4+} X_{6}$ (where $\mathrm{M}$ is the metal ion) are the other alternative and promising lead-free perovskite materials, that have been proposed for photovoltaic and other optoelectronic applications [48-50]. In this structure, two different metal ions with different oxidation states of $1+$ and $3+$, are substituted by two divalent $\mathrm{Pb}^{2+}$ metal ion in a three-dimensional perovskite structure. The space group of this lead-free perovskite materials is Fm3m with two different octahedra groups comprised of $\mathrm{M}^{+}$and $\mathrm{M}^{3+}$ in a rock salt face-centered cubic structure [50].

This review aims to focus on experimental and theoretical studies of Cs-based inorganic $\mathrm{Pb}$-free double halide perovskite materials in the form of $\mathrm{Cs}_{2} \mathrm{M}^{+} \mathrm{M}^{3+} \mathrm{X} 6\left(\mathrm{M}^{+}=\mathrm{Ag}^{+}\right.$, 
$\mathrm{Na}^{+}, \mathrm{In}^{+}$etc.; $\left.\mathrm{M}^{3+}=\mathrm{Bi}^{3+}, \mathrm{In}^{3+}, \mathrm{Sb}^{3+} ; \mathrm{X}=\mathrm{Cl}^{-}, \mathrm{Br}^{-}\right)$and $\mathrm{Cs}_{2} \mathrm{M}^{4+} \mathrm{X}_{6}\left(\mathrm{M}^{4+}=\mathrm{Ti}^{4+}, \mathrm{Sn}^{4+}, \mathrm{Au}^{4+}\right.$ etc.) alongside their results and applications in different optoelectronic devices, including solar cells, light-emitting diodes (LEDs), X-ray detectors, and photodetectors. We also present the effect of elemental substitution on the performances of these materials.

\section{Double Halide Perovskites}

The two key features of $\mathrm{Pb}$-based halide perovskites $\left(\mathrm{ABX}_{3}\right)$ which result in excellent optoelectronic properties are high symmetry of $\mathrm{BX}_{6}$ octahedral and the unique electronic configuration of $\mathrm{Pb}^{2+}\left(6 \mathrm{~s}^{2} 6 \mathrm{p}^{0}\right)$ which leads to strong $\mathrm{Pb} 6 \mathrm{~s}$ - I $5 \mathrm{p}$ antibonding coupling [51]. Therefore, to obtain a promising $\mathrm{Pb}$-free solar absorber candidate in perovskite structure, the symmetry of octahedra should be preserved. Octahedral rotation distortion, like twisting or tilting, may affect the symmetry properties of target crystals. In order to maintain high stability and high symmetry of cubic structure, two different parameters named Goldschmidt's tolerance factor $\left(t=R_{A}+R_{X}\right) /\left(\sqrt{ } 2\left(R_{B}+R_{X}\right)\right)$, and octahedral factor $\left(\mu=R_{B} / R x\right)$ should be considered. For ideal perovskite structure " $t$ " is between 0.8 and 1 and " $\mu$ " is larger than 0.414 [52].

Meanwhile, some research groups have considered other factors for designing efficient $\mathrm{Pb}$-free double halide perovskites for solar cell applications. Meng et al. [53], by carrying out a computational study suggested that inversion symmetry-induced parity-forbidden transitions should be considered for designing new double halide perovskites. In their study, they indicated that for most double halide perovskites with a direct bandgap like $\mathrm{Cs}_{2} \mathrm{AgInCl}_{6}$, transition from valance band maximum (VBM) to conduction band minimum (CBM) is forbidden because of inversion symmetry in their structure. And this is likely one of the reasons for their poor photovoltaic performance [53]. Xiao et al. [51] demonstrated that for gaining optimal and efficient lead-free halide perovskites for photovoltaic performance, besides structural dimensionality, electronic dimensionality should also be taken into account. This new concept explains that connectivity of electronic orbitals, which form the conduction band minimum (CBM) and valance band maximum (VBM), is another essential parameter for understanding the photovoltaic properties of all reported perovskites. Perovskites with three-dimensional (3D) crystal and electronic structures are the most desired for good photovoltaic performance [51].

Considering all important and affecting parameters, Zhao et al. [54], through the first-principals calculation exploited the cation transmutation idea to explore all-inorganic $\mathrm{Pb}$-free double halide perovskites for photovoltaic application by replacing $\mathrm{Pb}^{2+}$ by $\mathrm{Bi}^{3+}$ or $\mathrm{In}^{3+}$. Among 64 different potential considered candidates, only 11 compounds with intrinsic thermodynamic stability, suitable band gaps, small carrier effective masses, and low exciton binding energies have been identified as promising absorbers. Figure $1 \mathrm{a}, \mathrm{b}$ show the screening process of the materials based on properties like decomposition enthalpy $(\Delta \mathrm{H})$, carrier effective masses $\left(\mathrm{m}_{\mathrm{e}}{ }^{*}\right.$ and $\left.\mathrm{m}_{\mathrm{h}}{ }^{*}\right)$ and exciton binding energy $\left(\Delta \mathrm{E}_{\mathrm{b}}\right)$ [54]. In the following, we will present the successfully investigated Cs-based $\mathrm{Pb}$-free all-inorganic double halide perovskites with their current potential applications in various optoelectronic devices, along with the effect of elemental substitution on their optical and structural characterizes. 
(a)
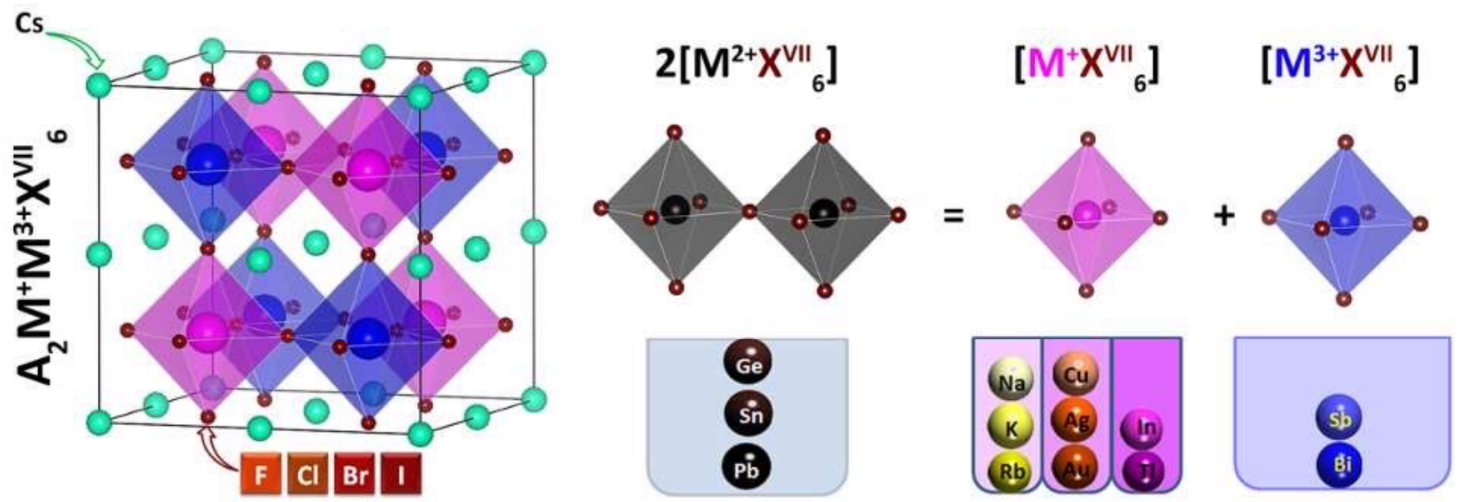

(b)

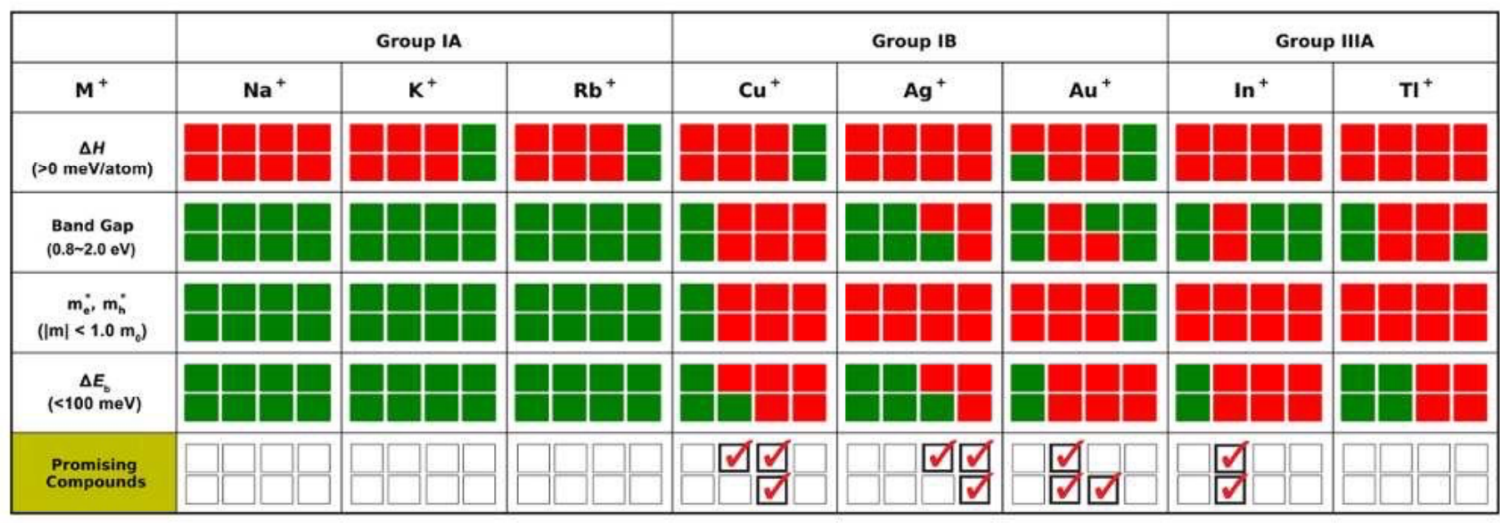

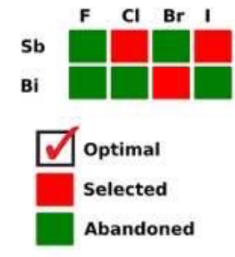

Figure 1. (a) Suggested structure of double halide perovskite with a formula of $\mathrm{A}_{2} \mathrm{~B}^{+} \mathrm{B}^{3+} \mathrm{X}_{6}$ using the idea of transmutation and; (b) materials screening process considering the decomposition enthalpy $(\Delta \mathrm{H})$, bandgap $\left(\mathrm{E}_{\mathrm{g}}\right)$, carrier effective masses $\left(\mathrm{m}_{\mathrm{e}}{ }^{*}\right.$ and $\left.\mathrm{m}_{\mathrm{h}}{ }^{*}\right)$ and exciton binding energy $(\Delta \mathrm{E})$. Reproduced with permission from [54]. Copyright 2017, American Chemical Society.

\section{1. $\mathrm{Cs} / \mathrm{Bi}^{3+}$-Based Double Halide Perovskites}

For many decades, Bi (bismuth) has been applied as an eco-friendly and non-toxic metal with interesting properties in diverse applications. Bi has been introduced as a suitable replacement for $\mathrm{Pb}$ because of comparable density and similar electronic configuration $[55,56]$. Due to the significant features, Bi has been one of the first examined candidates for developing Pb-free double halide perovskite materials for PV applications [48-50]. This idea was developed by three independent research groups which simultaneously, published their successful investigations by replacing $\mathrm{Pb}^{2+}$ with heterovalent substitution of $\mathrm{Bi}^{3+}$ and $\mathrm{Ag}^{+}$to form a lead-free double halide perovskite in 2016 [48-50].

For the sake of completeness, we have provided a list of $\mathrm{Cs} / \mathrm{Bi}^{3+}$-based halide double perovskites along with their theoretical and experimental bandgap values and other information including morphology and applied synthetic methods in Table 1 . In order to get a good overview, we present the results from theoretical and experimental studies separately. 
Table 1. Summary of prepared double halide perovskite samples based on inorganic $\mathrm{Cs} / \mathrm{Bi}^{3+}$.

\begin{tabular}{|c|c|c|c|c|c|c|c|c|}
\hline Compounds & Morphology & $\begin{array}{l}\text { Synthetic } \\
\text { Method }\end{array}$ & $\begin{array}{l}\text { Optical } \\
\text { Transition }\end{array}$ & $\begin{array}{c}\text { Theoretical } \\
\text { Bandgap }\end{array}$ & $\begin{array}{l}\text { Experimental } \\
\text { Bandgap }\end{array}$ & $\begin{array}{c}\text { Characterization } \\
\text { Techniques }\end{array}$ & $\begin{array}{l}\text { Theoretical } \\
\text { Calculation }\end{array}$ & Reference \\
\hline $\mathrm{Cs}_{2} \mathrm{AgBiBr}_{6}$ & $\begin{array}{l}\text { Powder and } \\
\text { single crystals }\end{array}$ & $\begin{array}{c}\text { Solution-based } \\
\text { process using } \\
\text { hydrohalic acid }\end{array}$ & Indirect & - & $1.95 \mathrm{eV}$ & $\begin{array}{c}\text { PL, UV-Vis } \\
\text { spectroscopy, TGA, } \\
\text { PXRD }\end{array}$ & - & [48] \\
\hline $\mathrm{Cs}_{2} \mathrm{AgBiBr}_{6}$ & polycrystalline & $\begin{array}{l}\text { Solution-based } \\
\text { process using } \\
\text { hydrohalic acid } \\
\text { process and solid-state } \\
\text { reaction }\end{array}$ & Indirect & $2.06 \mathrm{eV}$ & $2.19 \mathrm{eV}$ & $\begin{array}{c}\text { PL, UV-vis spectroscopy, } \\
\text { XRPD }\end{array}$ & DFT-VASP & [49] \\
\hline $\mathrm{Cs}_{2} \mathrm{AgBiBr}_{6}$ & Single crystals & $\begin{array}{l}\text { Solution-based } \\
\text { process using } \\
\text { hydrohalic acid with } \\
\text { high pressure } \\
\text { treatment }\end{array}$ & Indirect & $2.36 \mathrm{eV}$ & $\sim 1.7 \mathrm{eV}$ & $\begin{array}{l}\text { UV-Vis spectroscopy, } \\
\text { ADXRD, Raman }\end{array}$ & $\begin{array}{l}\text { DFT-LDA in } \\
\text { CASTEP }\end{array}$ & [56] \\
\hline $\mathrm{Cs}_{2} \mathrm{AgBiBr}_{6}$ & Single crystals & $\begin{array}{c}\text { Solution-based } \\
\text { process using } \\
\text { hydrohalic acid } \\
\text { process and solid-state } \\
\text { reaction }\end{array}$ & Indirect & $1.8 \mathrm{eV}$ & $1.9 \mathrm{eV}$ & $\begin{array}{c}\text { PXRD, UV-Vis } \\
\text { spectroscopy, PL }\end{array}$ & $\begin{array}{c}\text { DFT-LDA+SOC, } \\
\text { GW }\end{array}$ & [57] \\
\hline $\mathrm{Cs}_{2} \mathrm{AgBiBr}_{6}$ & - & - & Pseudo- direct & $0.44 \mathrm{eV}$ & - & - & $\begin{array}{c}\text { DFT/VASP/PAW } \\
\text { pseudopoten- } \\
\text { tials/PBEsol, } \\
\text { HSE06+SOC }\end{array}$ & [58] \\
\hline $\mathrm{Cs}_{2} \mathrm{AgBiBr}_{6}$ & Nanocrystals & Hot-injection method & Indirect & - & $2.33 \mathrm{eV}$ & $\begin{array}{l}\text { TEM, HTEM, XRD, } \\
\text { UV-Vis, PL }\end{array}$ & - & [59] \\
\hline $\mathrm{Cs}_{2} \mathrm{AgBiBr}_{6}$ & $\begin{array}{l}\text { Single crystals and } \\
\text { thin film }\end{array}$ & $\begin{array}{l}\text { Solution-based } \\
\text { process using } \\
\text { hydrohalic acid, slow } \\
\text { precipitation method }\end{array}$ & Indirect & - & $2.0 \mathrm{eV}$ & $\begin{array}{c}\text { TRPL, PL, PDS, UV-Vis } \\
\text { spectroscopy, X-ray } \\
\text { photoemission }\end{array}$ & - & {$[60]$} \\
\hline
\end{tabular}


Table 1. Cont.

\begin{tabular}{|c|c|c|c|c|c|c|c|c|}
\hline Compounds & Morphology & $\begin{array}{l}\text { Synthetic } \\
\text { Method }\end{array}$ & $\begin{array}{l}\text { Optical } \\
\text { Transition }\end{array}$ & $\begin{array}{c}\text { Theoretical } \\
\text { Bandgap }\end{array}$ & $\begin{array}{l}\text { Experimental } \\
\text { Bandgap }\end{array}$ & $\begin{array}{c}\text { Characterization } \\
\text { Techniques }\end{array}$ & $\begin{array}{l}\text { Theoretical } \\
\text { Calculation }\end{array}$ & Reference \\
\hline $\mathrm{Cs}_{2} \mathrm{AgBiBr}_{6}$ & $\begin{array}{l}\text { Single } \\
\text { crystals }\end{array}$ & $\begin{array}{l}\text { Solution-based } \\
\text { process using } \\
\text { hydrohalic acid }\end{array}$ & Indirect & $2.1 \mathrm{eV}$ & $2.12 \mathrm{eV}$ & Raman, PLE & DFT/Crystal17 & [61] \\
\hline $\mathrm{Cs}_{2} \mathrm{AgBiBr}_{6}$ & Thin film & $\begin{array}{l}\text { Solution-based } \\
\text { process }\end{array}$ & Indirect & $1.84 \mathrm{eV}$ & $2.10 \mathrm{eV}$ & UV-Vis spectroscopy & $\begin{array}{c}\text { DFT /PAW /VASP, } \\
\text { HSE06+SOC, } \\
\text { QTAIM/CRITIC2 }\end{array}$ & [62] \\
\hline $\mathrm{Cs}_{2} \mathrm{AgBiBr}_{6}$ & Polycrystals & Mechanochemical & Indirect & - & $2.0 \mathrm{eV}$ & $\begin{array}{c}\text { XRD, XPS, UV-Vis } \\
\text { spectroscopy, TG-DSC, } \\
\text { TCSPC, XRF }\end{array}$ & 2. & {$[63]$} \\
\hline $\mathrm{Cs}_{2} \mathrm{AgBiBr}_{6}$ & Thin film & $\begin{array}{c}\text { Solution-based } \\
\text { process using DMSO }\end{array}$ & Indirect & - & $2.12 \mathrm{eV}$ & $\begin{array}{c}\text { XRD, UV-Vis } \\
\text { spectroscopy, PL, SEM }\end{array}$ & - & [64] \\
\hline $\mathrm{Cs}_{2} \mathrm{AgBiBr}_{6}$ & Thin film & $\begin{array}{c}\text { Solution-based } \\
\text { process using DMSO }\end{array}$ & Indirect & - & $2.02 \mathrm{eV}$ & $\begin{array}{c}\text { XRD, UV-Vis } \\
\text { spectroscopy, PL, SEM, } \\
\text { EDX, XPS, AFM }\end{array}$ & - & {$[65]$} \\
\hline $\mathrm{Cs}_{2} \mathrm{AgBiBr}_{6}$ & Thin film & $\begin{array}{c}\text { Solution-based } \\
\text { process using DMSO }\end{array}$ & Indirect & - & $2.09 \mathrm{eV}$ & $\begin{array}{c}\text { XRD, UV-Vis } \\
\text { spectroscopy, PL, SEM }\end{array}$ & - & {$[66]$} \\
\hline $\mathrm{Cs}_{2} \mathrm{InBiBr}_{6}$ & $\begin{array}{l}\text { Powder and single } \\
\text { crystals }\end{array}$ & $\begin{array}{l}\text { solid-state } \\
\text { reaction }\end{array}$ & Direct & $0.33 \mathrm{eV}$ & - & PXRD, SCXRD & $\begin{array}{l}\text { DFT-VASP, } \\
\text { PBE+SOC }\end{array}$ & [67] \\
\hline $\mathrm{Cs}_{2} \mathrm{AgBiCl}_{6}$ & Polycrystalline & $\begin{array}{c}\text { Solution-based } \\
\text { process using } \\
\text { hydrohalic acid } \\
\text { process and solid-state } \\
\text { reaction }\end{array}$ & Indirect & $2.62 \mathrm{eV}$ & $2.77 \mathrm{eV}$ & $\begin{array}{c}\text { PL, UV-vis spectroscopy, } \\
\text { XRPD }\end{array}$ & DFT-VASP & [49] \\
\hline $\mathrm{Cs}_{2} \mathrm{AgBiCl}_{6}$ & Powder & Solid-state reaction & Indirect & $3.0 \mathrm{eV}$ & $2.2 \mathrm{eV}$ & $\begin{array}{c}\text { PXRD, UV-Vis } \\
\text { spectroscopy, PL }\end{array}$ & $\begin{array}{c}\text { DFT-LDA } \\
\text { Hybrid PBE0 }\end{array}$ & {$[50]$} \\
\hline $\mathrm{Cs}_{2} \mathrm{AgBiCl}_{6}$ & Single crystals & $\begin{array}{c}\text { Solution-based } \\
\text { process using } \\
\text { hydrohalic acid } \\
\text { process and solid-state } \\
\text { reaction }\end{array}$ & Indirect & $2.4 \mathrm{eV}$ & $2.2 \mathrm{eV}$ & $\begin{array}{c}\text { PXRD, UV-Vis } \\
\text { spectroscopy, PL }\end{array}$ & $\begin{array}{l}\text { DFT-LDA+SOC, } \\
\text { GW }\end{array}$ & [57] \\
\hline
\end{tabular}


Table 1. Cont.

\begin{tabular}{|c|c|c|c|c|c|c|c|c|}
\hline Compounds & Morphology & $\begin{array}{l}\text { Synthetic } \\
\text { Method }\end{array}$ & $\begin{array}{l}\text { Optical } \\
\text { Transition }\end{array}$ & $\begin{array}{c}\text { Theoretical } \\
\text { Bandgap }\end{array}$ & $\begin{array}{l}\text { Experimental } \\
\text { Bandgap }\end{array}$ & $\begin{array}{c}\text { Characterization } \\
\text { Techniques }\end{array}$ & $\begin{array}{l}\text { Theoretical } \\
\text { Calculation }\end{array}$ & Reference \\
\hline $\mathrm{Cs}_{2} \mathrm{AgBiCl}_{6}$ & Nanocrystals & Hot-injection method & Indirect & - & $2.89 \mathrm{eV}$ & $\begin{array}{l}\text { TEM, HTEM, XRD, } \\
\text { UV-Vis spectroscopy, PL }\end{array}$ & - & [59] \\
\hline $\mathrm{Cs}_{2} \mathrm{AgBiCl}_{6}$ & $\begin{array}{l}\text { Single crystals and } \\
\text { thin film }\end{array}$ & $\begin{array}{l}\text { Solution-based } \\
\text { process using } \\
\text { hydrohalic acid, slow } \\
\text { precipitation method }\end{array}$ & Indirect & - & $2.5 \mathrm{eV}$ & $\begin{array}{c}\text { TRPL, PL, PDS, UV-Vis } \\
\text { spectroscopy, X-ray } \\
\text { photoemission }\end{array}$ & - & {$[60]$} \\
\hline $\mathrm{Cs}_{2} \mathrm{InBiCl}_{6}$ & $\begin{array}{l}\text { Powder and single } \\
\text { crystals }\end{array}$ & solid-state reaction & Direct & $0.88 \mathrm{eV}$ & - & PXRD, SCXRD & $\begin{array}{l}\text { DFT-VASP, } \\
\text { PBE+SOC }\end{array}$ & [67] \\
\hline $\mathrm{Cs}_{2} \mathrm{InBiCl}_{6}$ & - -5 - & - & Direct & $1.02 \mathrm{eV}$ & - & 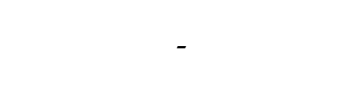 & $\begin{array}{l}\text { DFT, HSE+SOC, } \\
\text { PBE+SOC }\end{array}$ & {$[54]$} \\
\hline $\mathrm{Cs}_{4} \mathrm{CdBi}_{2} \mathrm{Cl}_{12}$ & Single crystals & Solvothermal & Direct forbidden & $3.58 \mathrm{eV}$ & $3.23 \mathrm{eV}$ & $\begin{array}{c}\text { PXRD, SC-XRD, TGA, } \\
\text { EDS, PL, PLE, TRPL, } \\
\text { UV-Vis-NIR } \\
\text { spectroscopy }\end{array}$ & $\begin{array}{c}\text { DFT/VASP/PAW, } \\
\text { GGA-PBE, } \\
\text { HSE+SOC }\end{array}$ & [68] \\
\hline
\end{tabular}




\subsection{1. $\mathrm{Cs}_{2} \mathrm{M}^{+} \mathrm{Bi}^{3+} \mathrm{X}_{6}$ : Theoretical Studies}

McClure et al. [49] studied $\mathrm{Cs}_{2} \mathrm{AgBiBr}_{6}$ and $\mathrm{Cs}_{2} \mathrm{AgBiCl}_{6}$ as the two first potential double halide perovskite compounds, by employing DFT analysis on VASP simulation software. The indirect bandgap of $2.06 \mathrm{eV}$ for $\mathrm{Cs}_{2} \mathrm{AgBiBr}_{6}$ and $2.62 \mathrm{eV}$ for $\mathrm{Cs}_{2} \mathrm{AgBiCl}_{6}$ were obtained as presented in Table 1 . According to the atomic partial density of states, the indirect bandgap resulted from the combination of Ag $4 d$ orbitals with halogens $3 p / 4 p$ orbitals which led to sufficient changes in the valence band as shown in Figure $2 a, b$. The study has also shown that hole effective masses were lighter $\left(\mathrm{Cs}_{2} \mathrm{AgBiCl}_{6}=0.15 \mathrm{~m}_{\mathrm{h}}\right.$; $\left.\mathrm{Cs}_{2} \mathrm{AgBiBr}_{6}=0.14 \mathrm{~m}_{\mathrm{h}}\right)$ than their $\mathrm{CsPbX}_{3}$ analogs $\left(\mathrm{CsPbCl}_{3}=0.35 \mathrm{~m}_{\mathrm{h}} ; \mathrm{CsPbBr}_{3}=0.37 \mathrm{~m}_{\mathrm{h}}\right)$ and the electron effective masses were also comparable $\left(\mathrm{Cs}_{2} \mathrm{AgBiCl}_{6}=0.53 \mathrm{~m}_{\mathrm{e}} ; \mathrm{Cs}_{2} \mathrm{AgBiBr}_{6}\right.$ $\left.=0.37 \mathrm{~m}_{\mathrm{e}}\right)$ with $\mathrm{CsPbX}_{3}$ compounds $\left(\mathrm{CsPbCl}_{3}=0.41 \mathrm{~m}_{\mathrm{e}} ; \mathrm{CsPbBr}_{3}=0.34 \mathrm{~m}_{\mathrm{e}}\right)$.

(a)

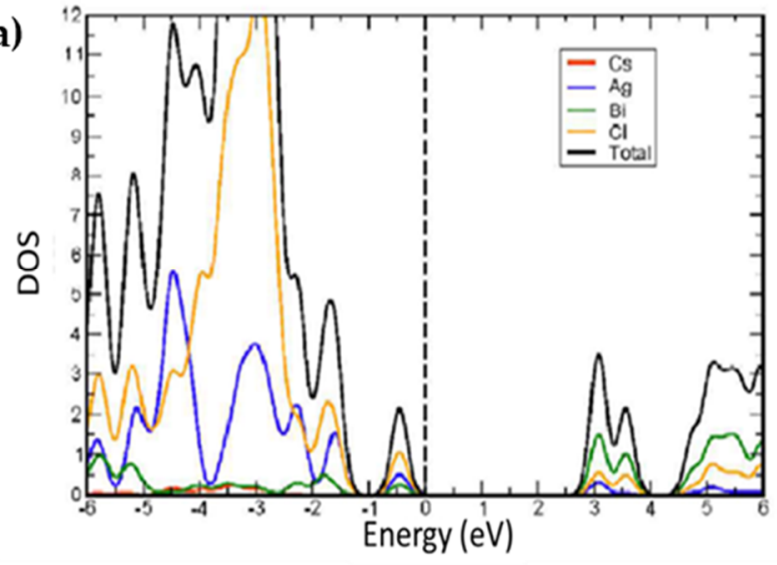

(b)

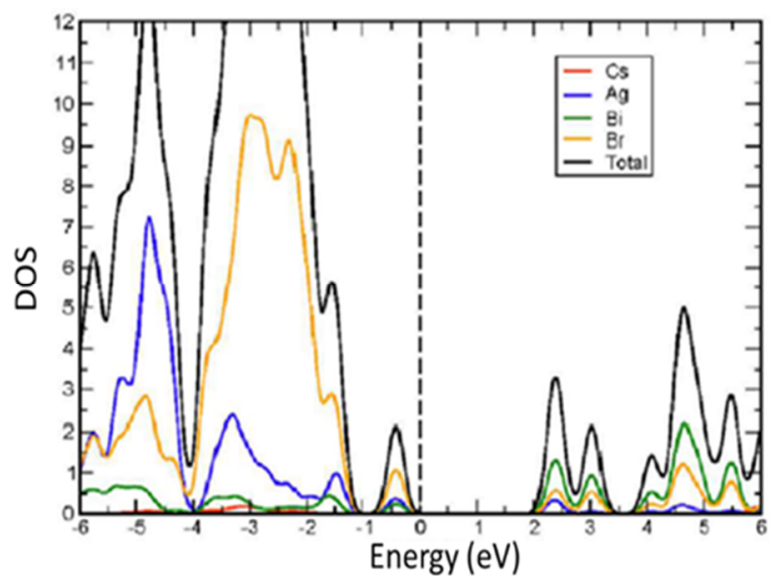

Figure 2. Atomic partial density of states for; (a) $\mathrm{Cs}_{2} \mathrm{AgBrBr}_{6}$ and; (b) $\mathrm{Cs}_{2} \mathrm{AgBrCl}_{6}$. Reproduced with permission from [49]. Copyright 2016, American Chemical Society.

Volonakis et al. [50] selected a different range of metals comprised of pnictogen $\left(\mathrm{Bi}^{3+}\right.$, $\mathrm{Sb}^{3+}$ (group VA of periodic table)) and noble metals $\left(\mathrm{Ag}^{+}, \mathrm{Au}^{+}, \mathrm{Cu}^{+}\right)$for computational and experimental studies. By using density functional theory in the local density approximation (DFT-LDA), they found all these compounds to have indirect bandgaps of less than $2.7 \mathrm{eV}$. By changing both halides from $\mathrm{I}^{-}$to $\mathrm{Cl}^{-}$and the pnictogen from $\mathrm{Bi}^{3+}$ to $\mathrm{Sb}^{3+}$, the bandgap was seen to be increasing. However, changing of the noble metals did not have any effect on this trend, since CBM and VBM mostly have pnictogen-p and halogen-p character, respectively. This means that by moving up in halogen (from $\mathrm{I}^{-}$to $\mathrm{Cl}^{-}$) and pnictogen group (from $\mathrm{Bi}^{3+}$ to $\mathrm{Sb}^{3+}$ ) in the periodic table, their p-state energy will be decreased, and consequently both VBM and CBM will be lowered. Another notable examined parameter was the smaller carrier effective masses in these compounds (between 0.1 and 0.4) compared to relevant $\mathrm{MAPbI}_{3}$.

Filip et al. [57] focused on the electronic properties of $\mathrm{Cs}_{2} \mathrm{AgBiX}_{6}\left(\mathrm{X}=\mathrm{Cl}^{-}\right.$and $\left.\mathrm{Br}^{-}\right)$ compounds through theoretical calculations. To obtain accurate bandgap values, they used the experimental crystal structures data within the DFT-LDA calculation in the quantum espresso suit with and without spin-orbit coupling. Based on obtained molecular orbitals diagram through the atom-projected density of states, they indicated that because of smaller energy difference in Ag-d and Br-p states in comparison with Ag-d and Cl-p, valence band width was reduced. Moreover, the delocalized nature of $\mathrm{Br}-4 \mathrm{p}$ orbitals resulted in more overlaps with Bi-6p, and thereby the width of conduction band increased as illustrated in Figure 3. Study of quasiparticle calculation for determination of the bandgap (1.8 eV for $\mathrm{Cs}_{2} \mathrm{AgBiBr}_{6}$ and $2.4 \mathrm{eV}$ for $\mathrm{Cs}_{2} \mathrm{AgBiCl}_{6}$ ) showed a good agreement with their experimental findings (1.9 eV for $\mathrm{Cs}_{2} \mathrm{AgBiBr}_{6}$ and $2.2 \mathrm{eV}$ for $\mathrm{Cs}_{2} \mathrm{AgBiCl}_{6}$ ) [57]. 


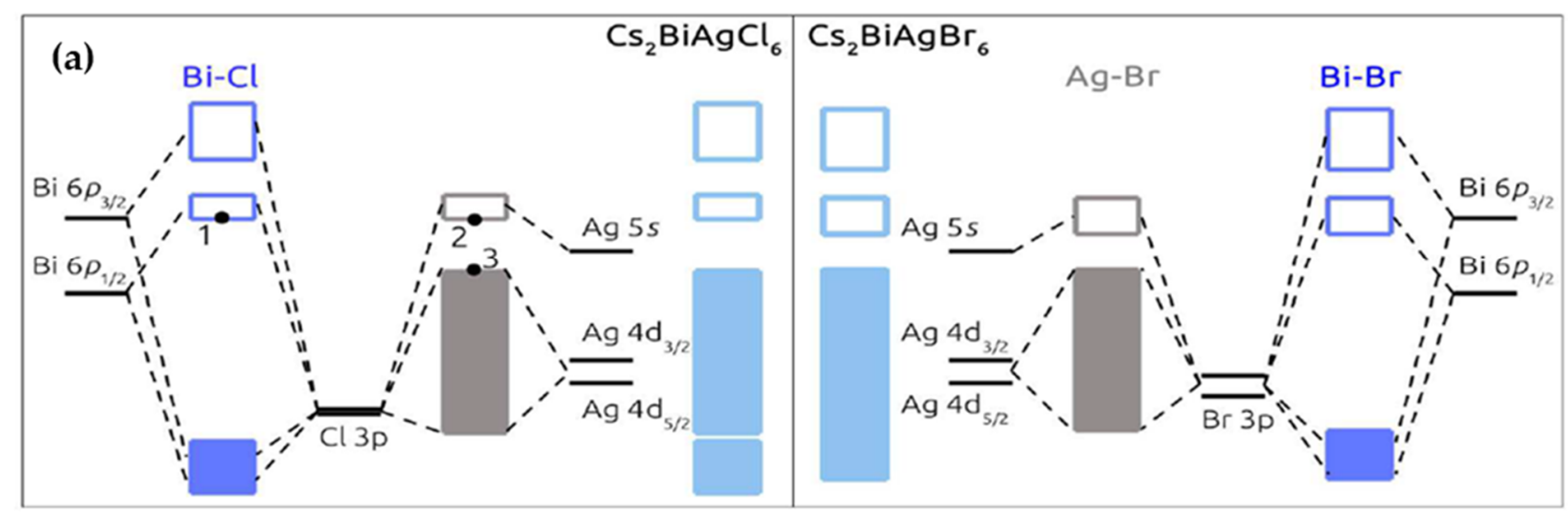

(b)
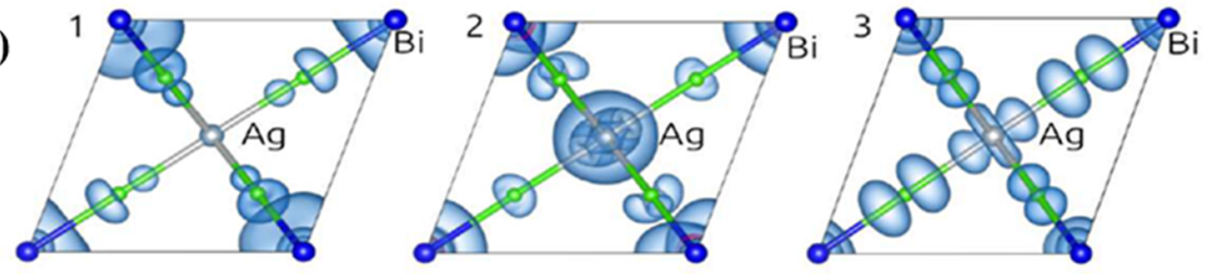

Figure 3. (a) Comparison between the molecular orbitals diagram of $\mathrm{Cs}_{2} \mathrm{AgBrCl}_{6}$ and $\mathrm{Cs}_{2} \mathrm{AgBrBr}_{6}$ and; (b) Square modulus of the wave functions for states marked from 1 to 3 on the molecular orbital diagram of $\mathrm{Cs}_{2} \mathrm{BiAgCl}_{6}$. 1 represents the Bi- $6 \mathrm{p}_{1 / 2} /$ halide- $\mathrm{p}$ antibonding orbitals at the bottom of the conduction band (at $\Gamma$ point). 2 is the antibonding Ag- $5 \mathrm{~s} / \mathrm{halide-p}$ at the L-point of the conduction band), while 3 corresponds to the Ag-4d/halide-p antibonding orbitals found at the top of the valence band (at X-point). Reproduced with permission from [57]. Copyright 2016, American Chemical Society.

Xiao et al. [69] investigated the thermodynamic stability of $\mathrm{Cs}_{2} \mathrm{AgBiBr}_{6}$ by DFT calculation, and claimed that $\mathrm{Ag}$ vacancies were shallow accepters that resulted in intrinsic p-type conductivity in $\mathrm{Cs}_{2} \mathrm{AgBiBr}_{6}$. On the other hand, the existence of some dominant deep defects such as $\mathrm{Bi}$ vacancies $\left(\mathrm{V}_{\mathrm{Bi}}\right)$ and $\mathrm{AgBi}$ antisites give rise to poor photovoltaic performance. Accordingly, Xiao et al. [69], in order to reduce the formation of deep defects, suggested that the synthesis of material preferably should be done under Bi-poor/Bi-rich growth conditions.

Xiao et al. [67] studied $\mathrm{Cs}_{2} \operatorname{In}^{+} \mathrm{M}^{3+} \mathrm{X}_{6}\left(\mathrm{M}=\mathrm{Bi}^{3+}\right.$, and $\mathrm{X}=$ halogens $)$ double halide perovskites, both theoretically and experimentally. Their results indicated that high-energylaying in $5 \mathrm{~s}^{2}$ state of $\mathrm{In}^{+}$is substantially responsible for promising photovoltaic performance. However, due to the oxidation of $\mathrm{In}^{+}$to $\mathrm{In}^{3+}$, and the reduction of $\mathrm{Bi}^{3+}$ to its metal form, the whole perovskite structure becomes unstable.

Since optimizing the bandgap is an important factor for enhancing the efficiency of PSCs, Yang et al. [58] proposed by changing the atomic arrangement in $\mathrm{Cs}_{2} \mathrm{AgBiBr}_{6}$ crystal structure, the bandgap can be narrowed. Using Monte Carlo and DFT calculations performed in VASP code by employing HSE06 with SOC, they showed that increasing the temperature up to $1200 \mathrm{~K}$ would increase the energy and consequently, phase transitions would occur. In this condition, $\mathrm{Ag}^{+}$and $\mathrm{Bi}^{3+}$ ions randomly occupy the $\mathrm{M}$-site in $\mathrm{A}_{2} \mathrm{M}^{+} \mathrm{M}^{3+} \mathrm{X}_{6}$ structure, and this leads to reduction of bandgap from $1.93 \mathrm{eV}$ to pseudo-direct bandgap of $0.44 \mathrm{eV}$.

\subsection{2. $\mathrm{Cs}_{2} \mathrm{M}^{+} \mathrm{Bi}^{3+} \mathrm{X}_{6}$ : Experimental Studies}

In this section, we provide detailed synthesis methods of $\mathrm{Cs} / \mathrm{Bi}^{3+}$-based double halide perovskites and their characterization results. This section based on obtained morphologies is divided into two categories, namely, crystalline and thin-film structures in 1.2.1 and 1.2.2, respectively. This detailed information of the experimental studies is also summarized in Table 1. 
- $\mathrm{Cs}_{2} \mathrm{M}^{+} \mathrm{Bi}^{3+} \mathrm{X}_{6}$ : Single-Crystals, Polycrystalline and Nanocrystals-Based Perovskites

Slaveney et al. [48] synthesized double halide perovskite $\mathrm{Cs}_{2} \mathrm{AgBiBr}_{6}$ with photoluminescence (PL) lifetime of approximately $660 \mathrm{~ns}$ with an indirect bandgap of $1.95 \mathrm{eV}$. Compared to $\mathrm{MAPbI}_{3}$, this compound showed higher stability against moisture and heat and had long room-temperature PL lifetime (736 ns to $1 \mu$ s for $\mathrm{MAPbI}_{3}$ films) which is a good characteristic for photovoltaic performance. Interestingly, the obtained PXRD (Powder X-ray diffraction) pattern did not show any evidence of material decompaction as shown in Figure 4a. Thermogravimetric analysis (TGA) showed that the material was stable up to $430^{\circ}$ which could be due to the replacement of unstable organic cation $\mathrm{MA}^{+}$ with $\mathrm{Cs}^{+}$ions as depicted in Figure $4 \mathrm{~b}$.
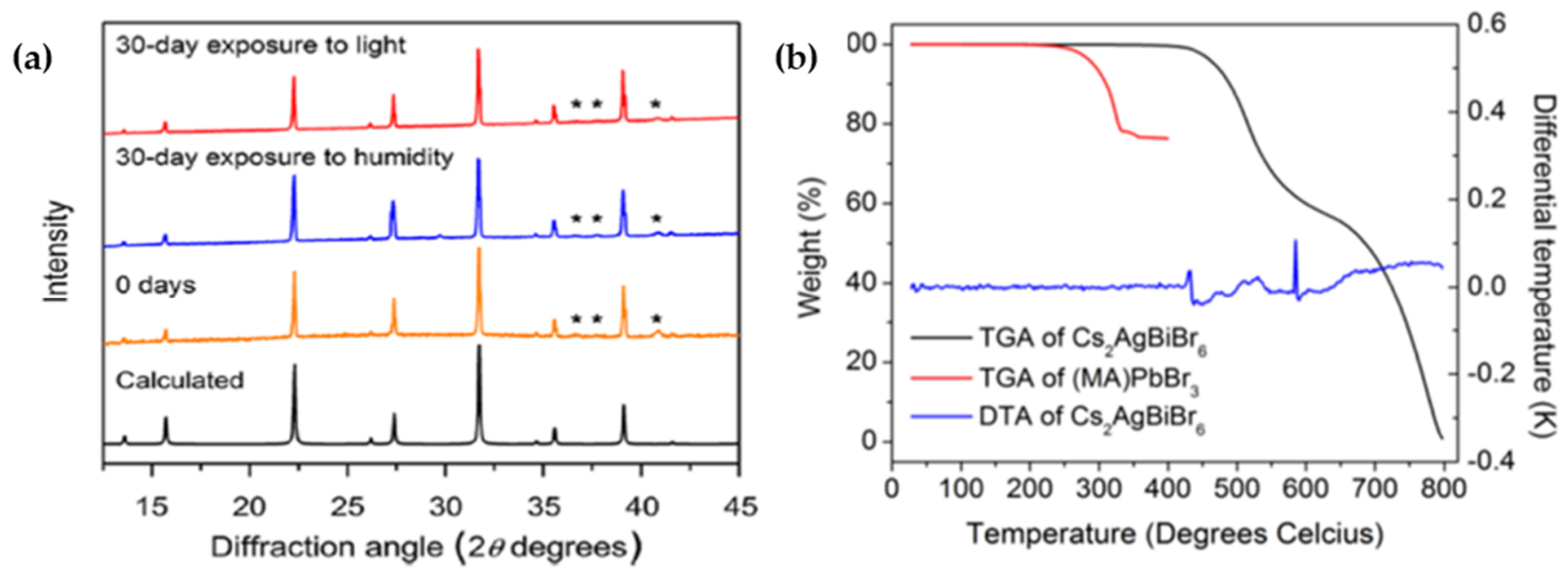

Figure 4. (a) PXRD pattern of $\mathrm{Cs}_{2} \mathrm{AgBiBr}_{6}$ after exposure to humidity (55\% RH) and light (0.75 Sun), ${ }^{*}$ and ${ }^{* *}$ refers to the signals from sample holder; (b) Thermogravimetric analyses of $\mathrm{Cs}_{2} \mathrm{AgBiBr}_{6}$ and $(\mathrm{MA}) \mathrm{PbBr}_{3}$ at a scan rate of $5^{\circ} \mathrm{C} / \mathrm{min}$ and $1{ }^{\circ} \mathrm{C} / \mathrm{min}$, respectively. Solid (MA)PbBr 3 shows an initial mass loss at $176^{\circ} \mathrm{C}$. Solid $\mathrm{Cs}_{2} \mathrm{AgBiBr}_{6}$ shows an initial mass loss at $430{ }^{\circ} \mathrm{C}$. DTA of $\mathrm{Cs}_{2} \mathrm{AgBiBr}_{6}$ shows no phase changes until the mass loss onset. Reproduced with permission from [48]. Copyright 2016, American Chemical Society.

McClure et al. [49] prepared polycrystalline $\mathrm{Cs}_{2} \mathrm{AgBiBr}_{6}$ and $\mathrm{Cs}_{2} \mathrm{AgBiCl}_{6}$ by applying solid state and solution-based methods. The PXRD analysis confirmed the 3D structure of these compounds in corner connected octahedra with alternating $\mathrm{Ag}^{+}$and $\mathrm{Bi}^{3+}$ in a rock salt ordering. However, according to PXRD and Rietveld refinements, due to large number of displacement parameters (Beq) and low bond valence sum of Cesium ion, phase transition could be expected below room temperature. UV-Vis diffuse reflectance spectra showed significant similarities between $\mathrm{Cs}_{2} \mathrm{AgBiX}_{6}$ and $\mathrm{Pb}$-based analogs $\left(\mathrm{CH}_{3} \mathrm{NH}_{3} \mathrm{PbX}_{3}\right)$ although there were some minor differences at photon energies above the absorption onset as shown in Figure 5a,b. Using Kubelka-Munk equation and Tauc plot, the optical indirect bandgap of $2.19 \mathrm{eV}$ and $2.77 \mathrm{eV}$ were obtained for $\mathrm{Cs}_{2} \mathrm{AgBiBr}_{6}$ and $\mathrm{Cs}_{2} \mathrm{AgBiCl}_{6}$, respectively which were close to their theoretically calculated values $\left(2.06 \mathrm{eV}\right.$ for $\mathrm{Cs}_{2} \mathrm{AgBiBr}_{6}$ and $2.62 \mathrm{eV}$ for $\left.\mathrm{Cs}_{2} \mathrm{AgBiCl}_{6}\right)$ [46]. In order to investigate the light and chemical stability, samples were placed in both dark and light conditions under ambient environment for one month. The obtained UV-Vis diffuse reflectance spectra analysis of the samples after 14 and 28 days exhibited that $\mathrm{Cs}_{2} \mathrm{AgBiBr}_{6}$ was less light stable than $\mathrm{Cs}_{2} \mathrm{AgBiCl}_{6}$ and the conclusion was that encapsulation of the structures might be needed for PV application. 

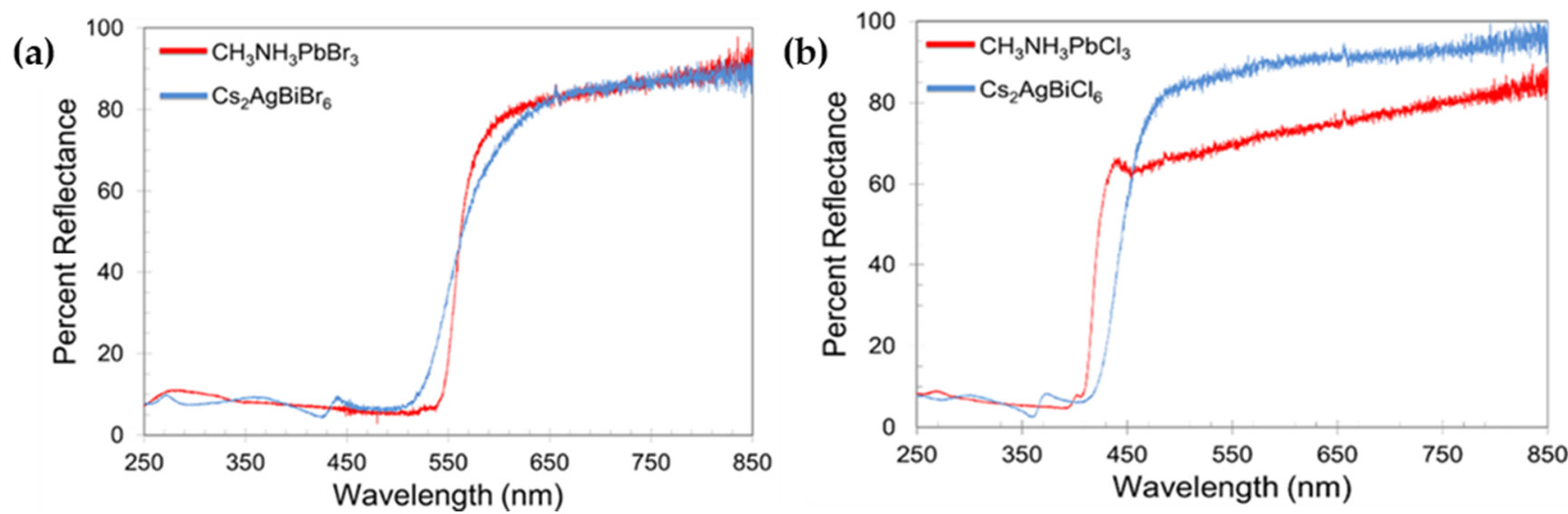

Figure 5. Diffuse reflectance spectra of; (a) $\mathrm{MAPbBr}_{3}$ and $\mathrm{Cs}_{2} \mathrm{AgBrBr}_{6}$; (b) $\mathrm{MAPbCl}_{3}$ and $\mathrm{Cs}_{2} \mathrm{AgBrCl}_{6}$. Reproduced with permission from [49]. Copyright 2016, American Chemical Society.

Volonakis et al. [50] successfully prepared single-phase $\mathrm{Cs}_{2} \mathrm{AgBiCl}_{6}$ samples through the solid-state reaction in a sealed fused silica ampoule. The structural and optical measurements by using single-crystal X-ray diffraction (SCXRD), UV-Vis spectroscopy and photoluminescence showed that the $\mathrm{Cs}_{2} \mathrm{AgBiCl}_{6}$ perovskite belongs to $\mathrm{Fm} 3 m$ space group while $\mathrm{BiCl}_{6}$ and $\mathrm{AgCl}_{6}$ octahedra are alternately placed in a rock-salt face-centered cubic structure with an indirect bandgap of $2.2 \mathrm{eV}$.

It is noticeable that the three abovementioned articles [48-50] presented different experimental bandgap values for $\mathrm{Cs}_{2} \mathrm{AgBiCl}_{6}(2.2 \mathrm{eV}$ to $2.7 \mathrm{eV})$ and $\mathrm{Cs}_{2} \mathrm{AgBiBr}_{6}(1.83 \mathrm{eV}$ to $2.19 \mathrm{eV}$ ) which is mainly due to the different synthesis methods (solid state preparation and solution processing) as well as utilizing different measurement techniques and methods such as UV-Vis spectroscopy and UV-Vis diffuse reflectance, Tauc plot, etc. for calculating bandgaps [57]. To overcome these discrepancies, Filip et al. [57] by employing the same solid state and solution-based synthesis methods prepared stable $\mathrm{Cs}_{2} \mathrm{AgBiBr}_{6}$ and $\mathrm{Cs}_{2} \mathrm{AgBiCl}_{6}$ single crystals under ambient environment. Through the optical measurements including UV-Vis spectroscopy and PL, they obtained an indirect bandgap of $1.9 \mathrm{eV}$ and $2.2 \mathrm{eV}$ for $\mathrm{Cs}_{2} \mathrm{AgBiBr}_{6}$ and $\mathrm{Cs}_{2} \mathrm{AgBiCl}_{6}$, respectively.

Xiao et al. [67] used $\mathrm{In}^{+}$instead of $\mathrm{Ag}^{+}$and synthesized $\mathrm{Cs}_{2} \mathrm{In}^{+} \mathrm{Bi}^{3+} \mathrm{X}_{6}(\mathrm{X}=$ halogens) double halide perovskites using solid-state reaction method. Their experimental investigation using SCXRD (Single Crystal X-ray diffraction) and PXRD exhibited that $\mathrm{In}^{+}$-based halide double perovskites spontaneously decomposes into $\mathrm{In}^{3+}$-based ternary materials such as $\mathrm{CsInI}_{4}, \mathrm{Cs}_{3} \mathrm{In}_{2} \mathrm{Br}_{9}$ and $\mathrm{Cs}_{3} \mathrm{In}_{2} \mathrm{Cl}_{9}$ (Figure 6a). In fact, $\mathrm{In}^{1+}$ is an unstable and unusual oxidation state in inorganic solids and there are only a few reported double perovskite compounds based on $\operatorname{In}^{+}[70,71]$. 

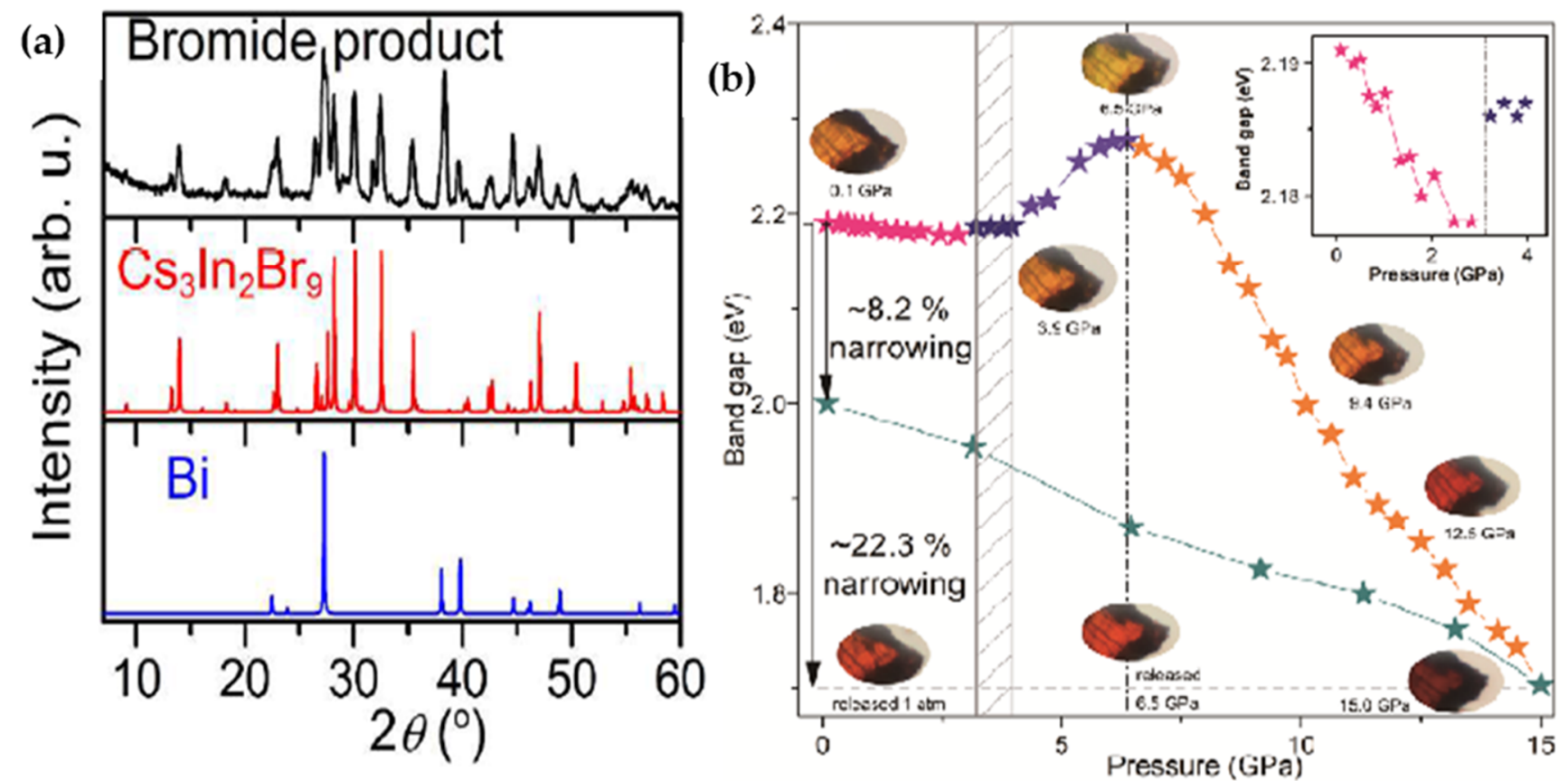

Figure 6. (a) PXRD pattern of the bromide product and simulated PXRD pattern for $\mathrm{Cs}_{3} \mathrm{In}_{2} \mathrm{Br}_{9}$ and Bi. Reproduced with permission [67]. Copyright 2017, American Chemical Society; (b) evolution of bandgap in $\mathrm{Cs}_{2} \mathrm{AgBrBr}_{6} \mathrm{structure}$ at high pressure with representative optical micrographs indicating piezochromic transitions. Reproduced with permission from [56]. Copyright 2017, Wiley-VCH.

Li et al. [56] by applying the high-pressure method, which previously had been used for size-dependent phase transformation [72] indicated that the bandgap of $\mathrm{Cs}_{2} \mathrm{AgBiBr}_{6}$ through high-pressure method was reduced by $22.3 \%$ from $2.2 \mathrm{eV}$ to $1.7 \mathrm{eV}$. Using UV-vis spectroscopy as optical measurement, they observed by increasing the pressure to $15 \mathrm{GPa}$, the color of the product changed to brown black and absorption peak exhibited a continues redshift. Interestingly, even after releasing the pressure, the bandgap value was observed to be around $\approx 2.0 \mathrm{eV}$ (Figure $6 \mathrm{~b}$ ).

The angle dispersive X-ray diffraction (ADXRD) analysis of the sample illustrated that by employing a wide range of pressure, a minimized octahedral tilting through $a b$ plane occurs, and this decreased the $\mathrm{Bi}-\mathrm{Br}-\mathrm{Ag}$ bond angle from $180^{\circ}$ to $166.4^{\circ}$. It is believed that this is one of the major factors of narrowing the bandgap of $\mathrm{Cs}_{2} \mathrm{AgBiBr}_{6}$.

In 2018, Hoye et al. [60] explored the carrier lifetime and recombination mechanism in the $\mathrm{Cs}_{2} \mathrm{AgBiBr}_{6}$ thin film in more detail. Both single crystals and thin film of $\mathrm{Cs}_{2} \mathrm{AgBiBr}_{6}$ were prepared through the slow precipitation method of saturated solution at low temperature. Based on optical measurements, the fundamental carrier lifetime for $\mathrm{Cs}_{2} \mathrm{AgBiBr}_{6}$ thin film was shown to be $1.4 \mu \mathrm{s}$. The carrier density of $\mathrm{Cs}_{2} \mathrm{AgBiBr}_{6}$ was calculated to be $2.2 \times 1016 \mathrm{~cm}^{-3}$ under 1 sun, which was larger than $\mathrm{MAPbI}_{3}$ steady-state carrier density $\left(5.2 \times 1015 \mathrm{~cm}^{-3}\right.$ under 1 sun). This clearly indicates the benefit of utilizing $\mathrm{Cs}_{2} \mathrm{AgBiBr}_{6}$ in solar cells.

Bekenstein et al. [59] selected hot-injection method for preparation of $\mathrm{Cs}_{2} \mathrm{AgBiBr}_{6}$ nanocrystals which previously was employed for synthesis of $\mathrm{CsPbX}$ and $\mathrm{CsPCl}_{3} \mathrm{NCs}$ by Protesescu et al. [73], and Xu et al. [74], respectively. The XRD and HRTEM analysis indicated that the crystals had the cubic Fm3m structure with the side length of 8-15 nm as shown in Figure 7a-c. 
(a)

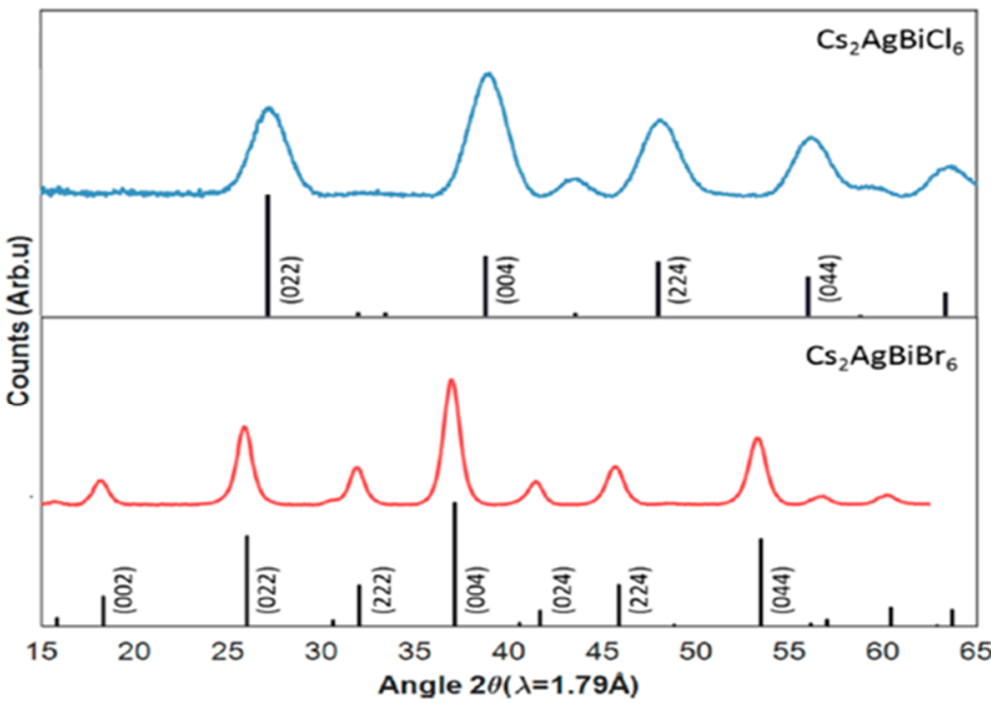

(b)

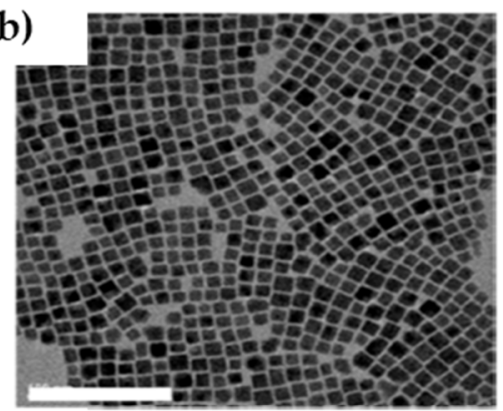

(c)

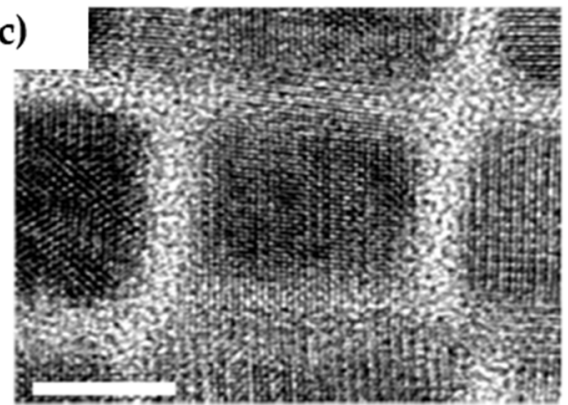

Figure 7. (a) XRD pattern of $\mathrm{Cs}_{2} \mathrm{AgBiBr}_{6}$ (red) and $\mathrm{Cs}_{2} \mathrm{AgBiCl}_{6}$ (blue) $\mathrm{NCs}$ in comparison with reported XRD patterns where scale bars refer to the other published XRD patterns for $\mathrm{Cs}_{2} \mathrm{AgBiBr}_{6}$ and $\mathrm{Cs}_{2} \mathrm{AgBiBr}_{6} \mathrm{Perovskites}$; (b) low-resolution and; (c) high-resolution TEM images of $\mathrm{Cs}_{2} \mathrm{AgBiBr}_{6} \mathrm{NCs}$ showing atomic lattice fringes. Reproduced with permission from [59]. Copyright 2018, American Chemical society.

The color of the sample was distinctly yellow, which was different from the previously prepared samples' color based on solid-state and solution-processed methods (orangered) [48-50]. The stability of the NCs was examined through the changing of solvents and changing of ligands. Solvents with higher polarity caused less stable NCs and by introducing the excess amount of primary and tertiary amines, absorption and emission features of the sample disappeared, which suggested that $\mathrm{Cs}_{2} \mathrm{AgBiBr}_{6}$ and $\mathrm{CsPbI}_{3}$ had similar surface chemistry. Furthermore, it was demonstrated [59], due to the Ag diffusion, reduction and coalescence, $\mathrm{Cs}_{2} \mathrm{AgBiBr}_{6} \mathrm{NCs}$ in solution were structurally unstable and degraded to $\mathrm{Cs}_{3} \mathrm{Bi}_{2} \mathrm{Br}_{9}$ and $\mathrm{Cs}_{3} \mathrm{BiBr}_{6}$ byproduct $\mathrm{NCs}$. However, by controlling the solvents evaporation rate, less degradation was occurred on NCs superlattices assembled into the ordered NC solids including strong ligand-ligand interaction.

Zhang et al. [75], as presented in Table 2, replaced $\mathrm{Ag}^{+}$in Bi-based halide double perovskite with $\mathrm{Na}^{+}$ion for fabricating the solar cell, and $\mathrm{Cs}_{2} \mathrm{NaBiI}_{6}$ perovskite was synthesized by facile one-step hydrothermal process. The material showed tolerance factor of 0.849 and octahedral factor of 0.466 with bandgap of $1.66 \mathrm{eV}$. The SEM images showed by increasing the concentration of solvent $(\mathrm{HI})$, up to $6 \mathrm{M}$, the crystal growth got improved as shown in Figure 8a,b. 

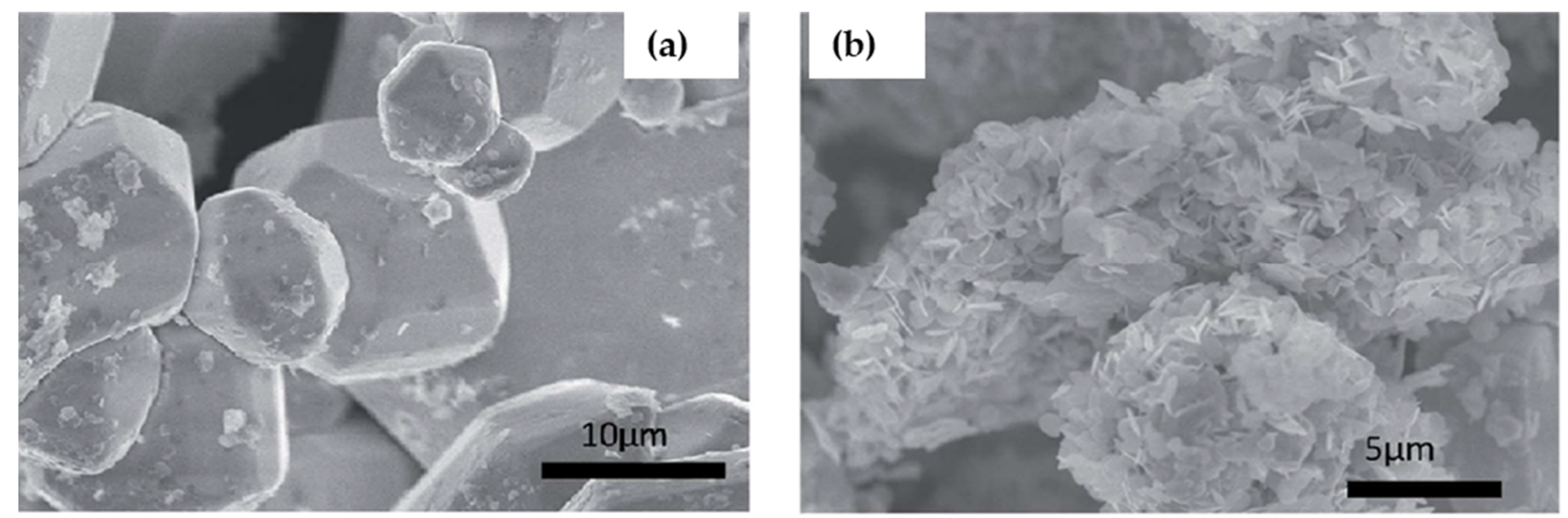

Figure 8. (a) multiple shuttle-like crystals from high acidity synthesis and; (b) clusters of nano-plates from non-acid synthesis. Reproduced with permission from [75]. Copyright 2018, Royal Society of Chemistry.

In 2019, Zelewski et al. [61] by combination of photoluminescence excitation (PLE) and Raman spectroscopy demonstrated that the PL emission in $\mathrm{Cs}_{2} \mathrm{AgBiBr}_{6}$, was dominated by the strong electron-phonon coupling due to the relatively large Huang-Rhys factor $(S=11.7)$. It was also revealed that the excitation resonant of the color center in ionic crystals of $\mathrm{Cs}_{2} \mathrm{AgBiBr}_{6}$ was more responsible for the PL emission rather than band to band transition. It was also proven that the color centers of ionic crystals were coupled with crystal lattice vibrations [76]. Local lattice deformation would occur if any of these centers were occupied. This led to energy offset in color center between ground state (unoccupied) and excited states (occupied) [61].

- $\mathrm{Cs}_{2} \mathrm{M}^{+} \mathrm{Bi}^{3+} \mathrm{X}_{6}$ : Film-Based Perovskites

In following section, we present the studies in which $\mathrm{Cs}_{2} \mathrm{M}^{+} \mathrm{Bi}^{3+} \mathrm{X}_{6}$ perovskites prepared as thin film for PV application and the results are presented in Table 2.

Although other research groups were employing halide acids as solvent, in 2017, Greul et al. [77] for the first time used dimethyl sulfoxide (DMSO) as the solvent in the synthesis of $\mathrm{Cs}_{2} \mathrm{AgBiBr}_{6}$ film. By annealing at temperatures higher than $250^{\circ}$ all the side phases such as $\mathrm{AgBr}$ and $\mathrm{Cs}_{3} \mathrm{Bi}_{2} \mathrm{Br}_{9}$ were removed. They reported that adopting a preheating step at $75^{\circ}$ right before the spin coating of $\mathrm{Cs}_{2} \mathrm{AgBiBr}_{6}$ film led to enhanced surface coverage and increased optical absorption. However, the $\mathrm{Cs}_{2} \mathrm{AgBiBr}_{6}$ film exhibited faster photoluminescence decay time (220 ns) in comparison with polycrystalline powders (568 ns) due to their large concentration of trap states (Figure 9a). Also, SEM images of the film indicated some agglomeration on the surface of spin coated film which contributed to the fast crystallization process (Figure $9 \mathrm{~b}, \mathrm{c}$ ). 
Table 2. Prepared device architecture and photovoltaic parameters of Cs-based double halide perovskite solar cells.

\begin{tabular}{|c|c|c|c|c|c|c|c|c|}
\hline $\begin{array}{c}\text { Perovskite } \\
\text { Material }\end{array}$ & Year & $\begin{array}{c}\text { Device } \\
\text { Architecture }\end{array}$ & $\begin{array}{c}\text { Perovskite } \\
\text { Deposition Method }\end{array}$ & $\begin{array}{l}\mathbf{V}_{\text {oc }} \\
{[\mathrm{V}]}\end{array}$ & $\begin{array}{c}\mathrm{J}_{\mathrm{sc}} \\
{\left[\mathrm{mA}^{-2} \mathrm{~cm}^{-2}\right]}\end{array}$ & FF & $\begin{array}{l}\text { PCE } \\
{[\%]}\end{array}$ & Reference \\
\hline $\mathrm{Cs}_{2} \mathrm{AgBiBr}_{6}$ & 2017 & $\begin{array}{c}\mathrm{FTO} / \mathrm{c}-\mathrm{TiO}_{2} / \mathrm{mp}^{-} \\
\mathrm{TiO}_{2} / \text { perovskite/spiro- } \\
\text { OMeTAD/Au }\end{array}$ & $\begin{array}{l}\text { One-step spin coating } \\
\text { with preheating }\end{array}$ & 0.98 & 3.93 & 0.63 & 2.43 & [77] \\
\hline $\mathrm{Cs}_{2} \mathrm{AgBiBr}_{6}$ & 2018 & $\begin{array}{c}\mathrm{ITO} / \mathrm{SnO}_{2} / \\
\text { perovskite/P3HT/Au }\end{array}$ & $\begin{array}{l}\text { One-step spin coating } \\
\text { with low-pressure } \\
\text { assisted method }\end{array}$ & 1.04 & 1.78 & 0.78 & 1.44 & [78] \\
\hline $\mathrm{Cs}_{2} \mathrm{AgBiBr}_{6}$ & 2018 & $\begin{array}{c}\text { ITO/c- } \\
\mathrm{TiO}_{2} / \text { perovskite/ } \\
\text { spiro-OMeTAD/Au }\end{array}$ & One-step spin coating & 1.06 & 1.55 & 0.74 & 1.22 & [79] \\
\hline $\mathrm{Cs}_{2} \mathrm{AgBiBr}_{6}$ & 2018 & $\begin{array}{c}\mathrm{FTO} / \mathrm{c}-\mathrm{TiO}_{2} / \mathrm{mp}- \\
\mathrm{TiO}_{2} / \text { perovskite } \\
\text { PTAA / Au }\end{array}$ & $\begin{array}{c}\text { One-step spin coating } \\
\text { with anti-solvent } \\
\text { dropping } \\
\text { methodology }\end{array}$ & 1.02 & 1.84 & 0.67 & 1.26 & [80] \\
\hline $\mathrm{Cs}_{2} \mathrm{AgBiBr}_{6}$ & 2018 & $\begin{array}{c}\mathrm{ITO} / \mathrm{Cu}- \\
\mathrm{NiO} / \text { perovskite/ } \\
\mathrm{C60} / \mathrm{BCP} / \mathrm{Ag}\end{array}$ & $\begin{array}{l}\text { One-step spin coating } \\
\text { with anti-solvent } \\
\text { dropping } \\
\text { methodology and } \\
\text { post-annealing }\end{array}$ & 1.01 & 3.19 & 0.69 & 2.23 & [81] \\
\hline $\mathrm{Cs}_{2} \mathrm{NaBiI}_{6}$ & 2018 & $\begin{array}{c}\mathrm{FTO} / \mathrm{c}-\mathrm{TiO}_{2} / \\
\text { perovskite/P3HT/Au }\end{array}$ & One-step spin coating & 0.47 & 1.99 & 0.44 & 0.42 & [75] \\
\hline $\mathrm{Cs}_{2} \mathrm{AgBiBr}_{6}$ & 2018 & $\begin{array}{c}\mathrm{FTO} / \mathrm{c}-\mathrm{TiO}_{2} / \mathrm{mp}- \\
\mathrm{TiO}_{2} / \text { perovskite/ } \\
\text { spiro-OMeTAD/Au }\end{array}$ & $\begin{array}{l}\text { Sequential vapor } \\
\text { deposition with two } \\
\text { step annealing }\end{array}$ & 1.12 & 1.79 & - & 1.37 & [82] \\
\hline $\mathrm{Cs}_{2} \mathrm{AgBiBr}_{6}$ & 2019 & $\begin{array}{c}\mathrm{FTO} / \mathrm{TiO}_{2} / \\
\text { perovskite/ } \\
\text { SpiroOMeTAD/ } \\
\mathrm{MoO}_{3} / \mathrm{Ag}\end{array}$ & $\begin{array}{c}\text { Vacuum sublimation } \\
\text { and one-step spin } \\
\text { coating }\end{array}$ & 1.01 & 3.82 & 0.65 & 2.51 & [83] \\
\hline $\mathrm{Cs}_{2} \mathrm{AgBiBr}_{6}$ & 2020 & $\begin{array}{c}\mathrm{ITO} / \mathrm{SnO}_{2} / \\
\text { perovskite } / \mathrm{Zn}-\mathrm{Chl} \\
/ \mathrm{Ag}\end{array}$ & One-step spin coating & 0.99 & 3.83 & 0.736 & 2.79 & {$[64]$} \\
\hline $\mathrm{Cs}_{2} \mathrm{AgBiBr}_{6}$ & 2020 & 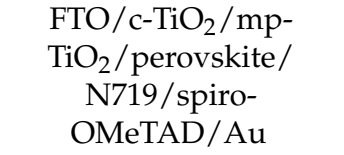 & $\begin{array}{c}\text { One-step spin coating } \\
\text { with two-step heating } \\
\text { process. }\end{array}$ & 1.06 & 5.13 & 0.524 & 2.84 & [65] \\
\hline $\mathrm{Cs}_{2} \mathrm{AgBiBr}_{6}$ & 2021 & $\begin{array}{c}\mathrm{FTO} / \mathrm{c}-\mathrm{TiO}_{2} / \mathrm{mp}- \\
\mathrm{TiO}_{2} / \mathrm{C}- \\
\text { Chl/perovskite/spiro- } \\
\text { OMeTAD/Au }\end{array}$ & One-step spin coating & 1.04 & 4.09 & 0.73 & 3.11 & [66] \\
\hline $\begin{array}{l}\left(\mathrm{Cs}_{1-\mathrm{x}} \mathrm{Rb}_{\mathrm{x}}\right)_{2} \\
\mathrm{AgBiBr}_{6}\end{array}$ & 2019 & $\begin{array}{l}\mathrm{ITO} / \mathrm{SnO}_{2} / \text { perovskite/ } \\
\text { spiro-OMeTAD/Au }\end{array}$ & $\begin{array}{l}\text { One-step spin coating } \\
\text { with low-pressure } \\
\text { assisted method }\end{array}$ & 0.99 & 1.93 & 0.78 & 1.52 & {$[84]$} \\
\hline $\mathrm{Cs}_{2} \mathrm{AgSbBr}_{6}$ & 2019 & $\begin{array}{c}\mathrm{FTO} / \mathrm{c}-\mathrm{TiO}_{2} / \mathrm{mp}- \\
\mathrm{TiO}_{2} / \text { perovskite/ } \\
\text { spiro-OMeTAD/Au }\end{array}$ & One-step spin coating & 0.35 & 0.080 & 0.35 & 0.01 & [85] \\
\hline $\mathrm{Cs}_{2} \mathrm{SnI}_{6}$ & 2017 & $\begin{array}{c}\mathrm{FTO} / \mathrm{c}^{-} \\
\mathrm{TiO}_{2} / \text { perovskite/ } \\
\mathrm{P} 3 \mathrm{HT} / \mathrm{Ag}\end{array}$ & $\begin{array}{l}\text { Two-step sequential } \\
\text { vapor deposition }\end{array}$ & 0.51 & 5.41 & 0.35 & 0.96 & [86] \\
\hline $\mathrm{Cs}_{2} \mathrm{TiBr}_{6}$ & 2018 & $\begin{array}{c}\mathrm{FTO} / \mathrm{TiO}_{2} / \mathrm{C} 60 / \\
\text { perovskite/P3HT/Au }\end{array}$ & $\begin{array}{c}\text { Facile } \\
\text { low-temperature } \\
\text { vapor deposition }\end{array}$ & 1.02 & 5.69 & 0.564 & 3.3 & [87] \\
\hline
\end{tabular}


(a)
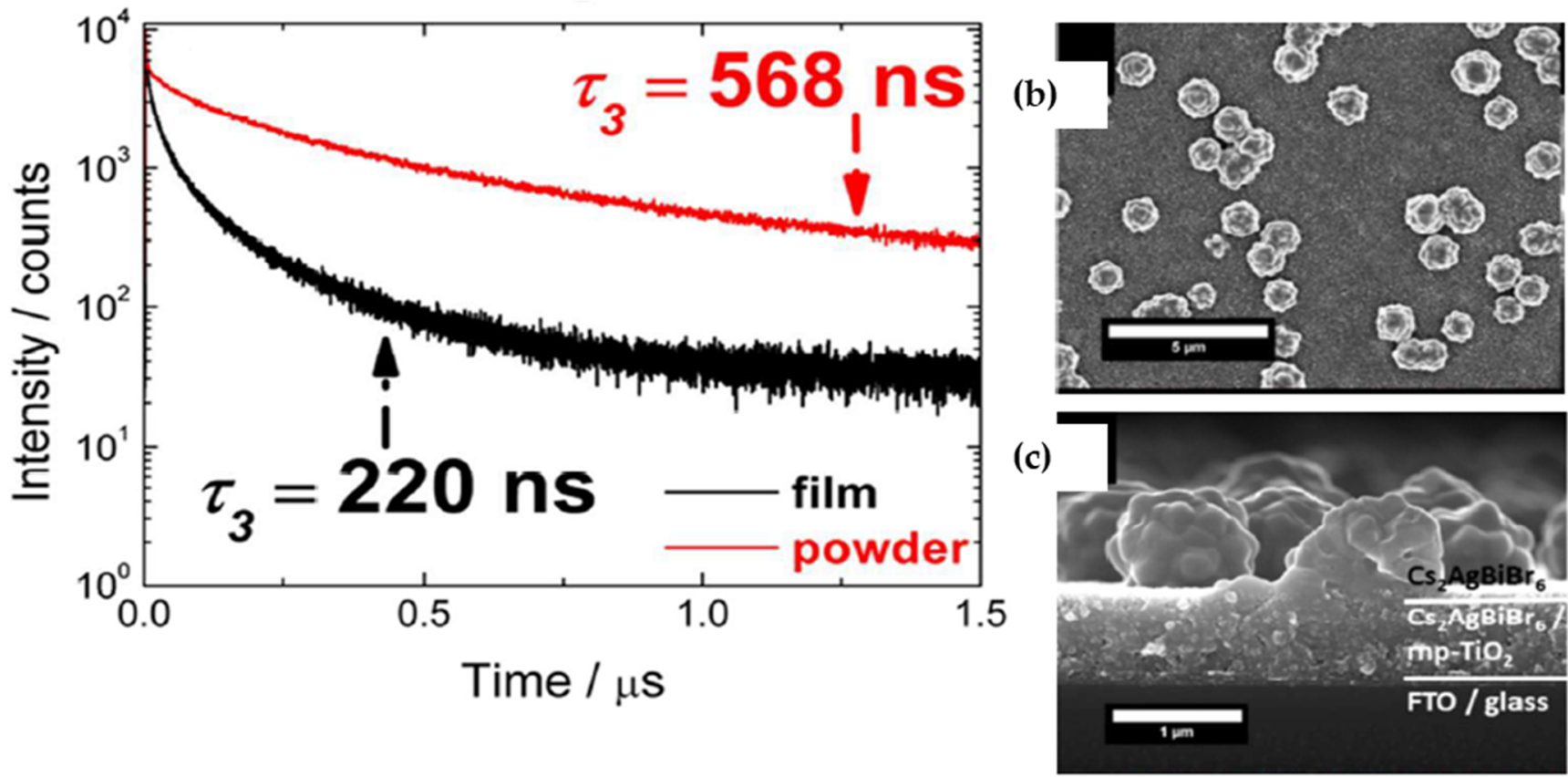

Figure 9. (a) TCSPC decays of a $\mathrm{Cs}_{2} \mathrm{AgBiBr}_{6}$ film on glass and polycrystalline powder; (b) SEM top-view and; (c) SEM crosssection images of the $\mathrm{Cs}_{2} \mathrm{AgBiBr}_{6}$ film prepared with a $75^{\circ} \mathrm{C}$ preheating step on $\mathrm{mp}-\mathrm{TiO}_{2}$. Reproduced with permission from [77]. Copyright 2017, Royal Society of Chemistry.

$\mathrm{Wu}$ et al. [78] employed low-pressure assisted (LPA) method for preparation of $\mathrm{Cs}_{2} \mathrm{AgBiBr}_{6}$ film. In this method, as-synthesized $\mathrm{Cs}_{2} \mathrm{AgBiBr}_{6}$ powder [48] was dissolved in DMSO and then spin-coated on an ITO/glass substrate. The prepared film then was quickly moved to a low-pressure chamber (20 Pa) and finally was annealed thermally (Figure 10a,b). Using the LPA method led to enhanced crystallinity and grain size.

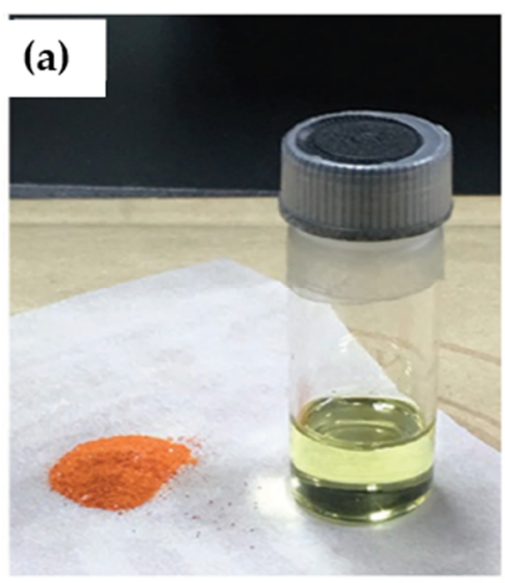

(b)

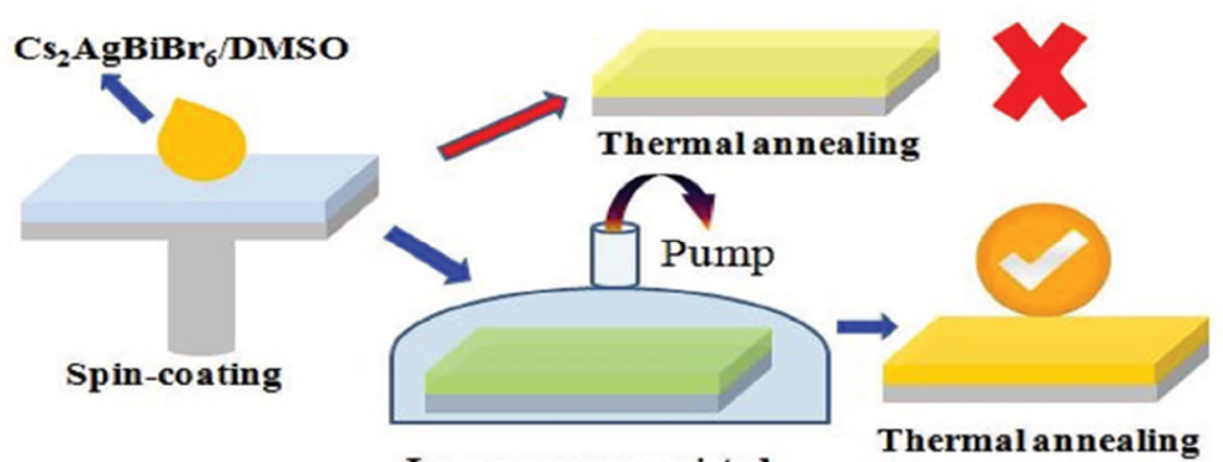

Low-pressure assisted

Figure 10. (a) images of $\mathrm{Cs}_{2} \mathrm{AgBiBr}_{6}$ powder and $\mathrm{Cs}_{2} \mathrm{AgBiBr}_{6}$ solution in DMSO and; (b) the film fabrication process diagram. Reproduced with permission from [78]. Copyright 2018, Wiley-VCH.

Gao et al. [81] inspired by the LPA synthesis method [88], adopted an anti-solvent dropping methodology for synthesis of $\mathrm{Cs}_{2} \mathrm{AgBiBr}_{6}$ film as depicted in Figure 11a,b. Combination of this method with post-annealing at high temperature resulted in smooth morphology, micro-sized grains and high crystallinity (Figure 11c).

Pantaler et al. [80] used chlorobenzene as anti-solvent before the annealing step during the film formation to obtain the smooth layer without any pinholes (Figure 12a). The SEM images of the film showed crystal grain size of $80 \mathrm{~nm}$ and $200 \mathrm{~nm}$ thickness (Figure 12b). 


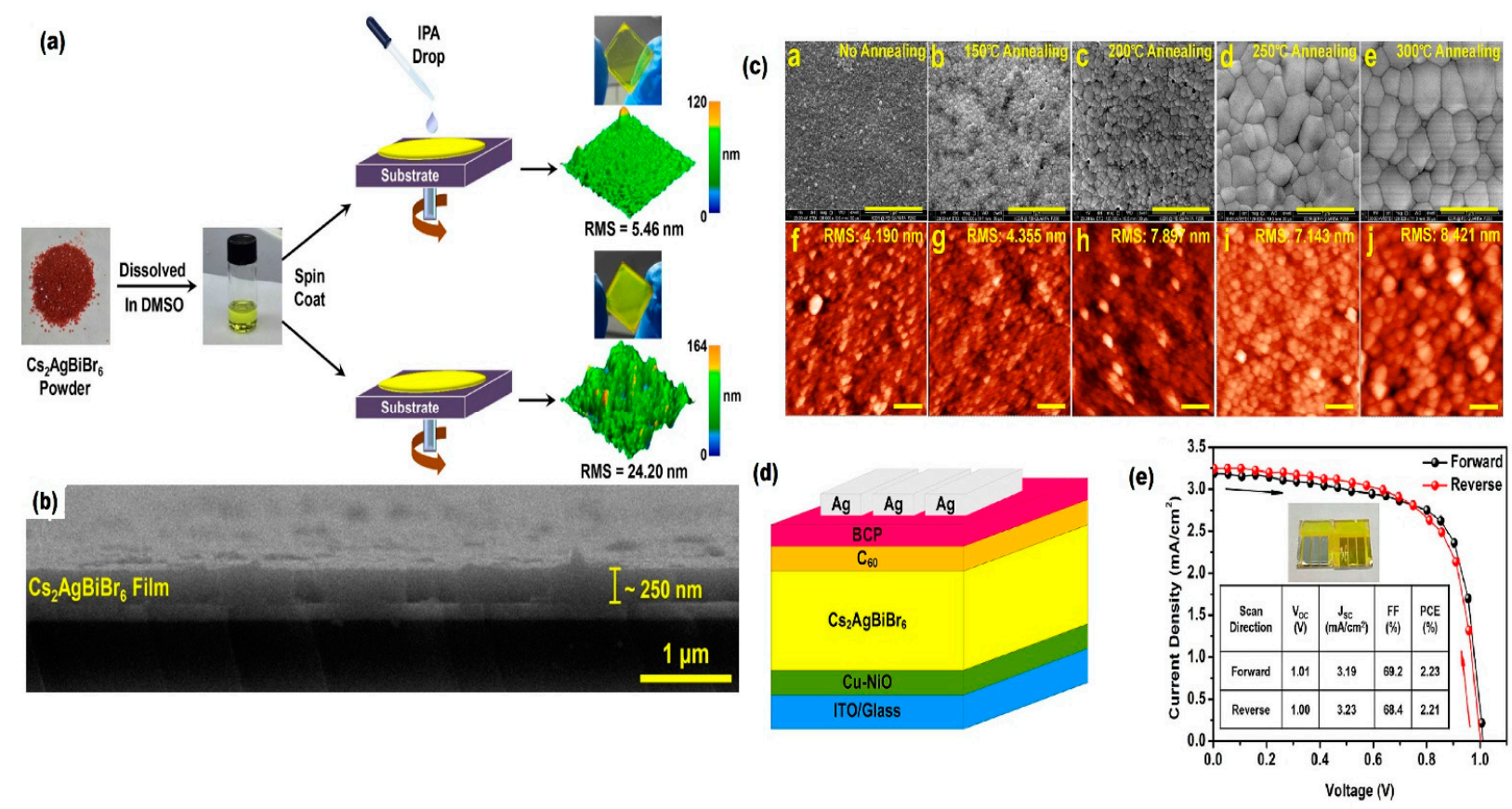

Figure 11. (a) Schematic illustration of the spin-coating process (with and without anti-solvent dropping protocol); (b) Cross-sectional SEM image of a $\mathrm{Cs}_{2} \mathrm{AgBiBr}_{6}$ film obtained by IPA dipping; (c) SEM images and AFM images of $\mathrm{Cs}_{2} \mathrm{AgBiBr}_{6}$ films annealed at different temperatures; (d) Structure of the inverted PSC devices fabricated in this work and; (e) J-V curves of the best-performing device based on $\mathrm{Cs}_{2} \mathrm{AgBiBr}_{6}$ films obtained at different fabrication conditions. Reproduced with permission from [81]. Copyright 2018, Wiley-VCH.
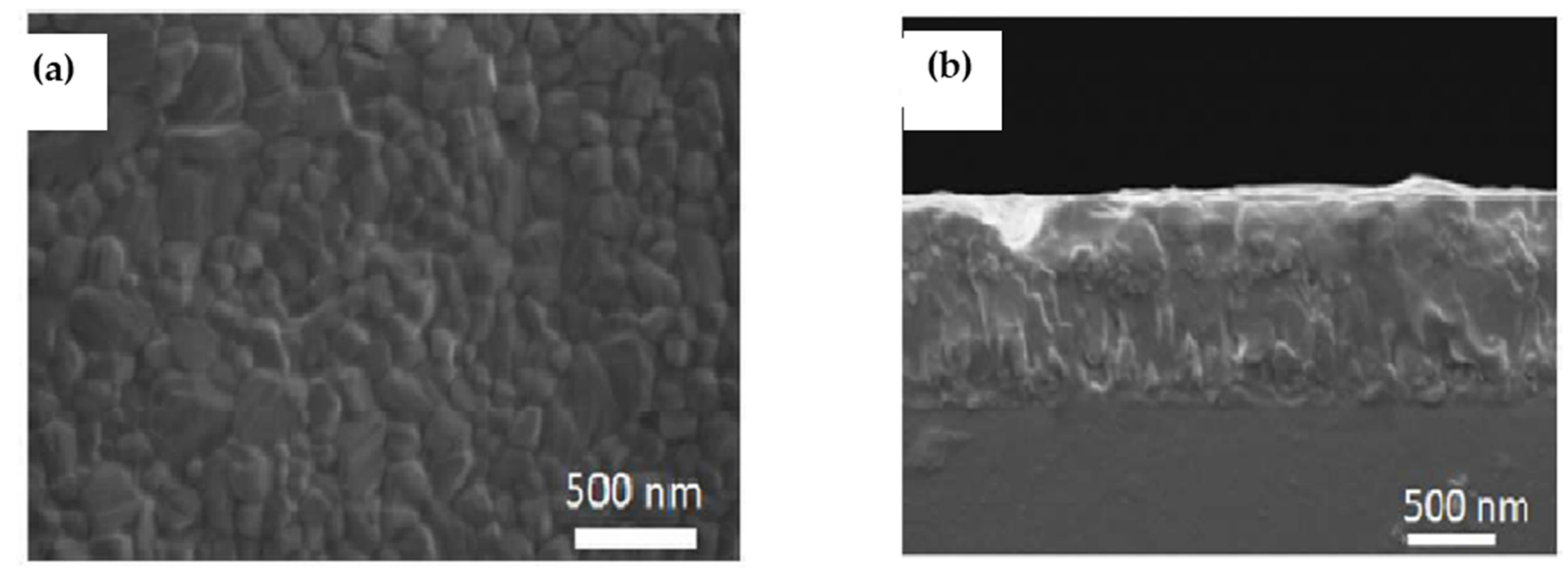

Figure 12. (a) Top-view SEM image of obtained $\mathrm{Cs}_{2} \mathrm{AgBiBr}_{6}$ film by spin coating at room temperature using the anti-solvent treatment with chlorobenzene; (b) cross-section SEM image of $\mathrm{FTO} / \mathrm{c}-\mathrm{TiO}_{2} / \mathrm{m}-\mathrm{TiO}_{2} /$ double perovskite sample, upon annealing at $280^{\circ} \mathrm{C}$. Reproduced with permission from [80]. Copyright 2018, American Chemical Society.

Wang et al. [82] employed the sequential-vapor-deposition procedure for the synthesis of $\mathrm{Cs}_{2} \mathrm{AgBiBr}_{6}$ film as depicted in Figure 13. To obtain an optimized film, annealing was carried out in two different steps. The film was first annealed at $200^{\circ}$ for $5 \mathrm{~h}$, which was then followed by annealing at $240^{\circ}$ to form the double halide perovskite phase. 


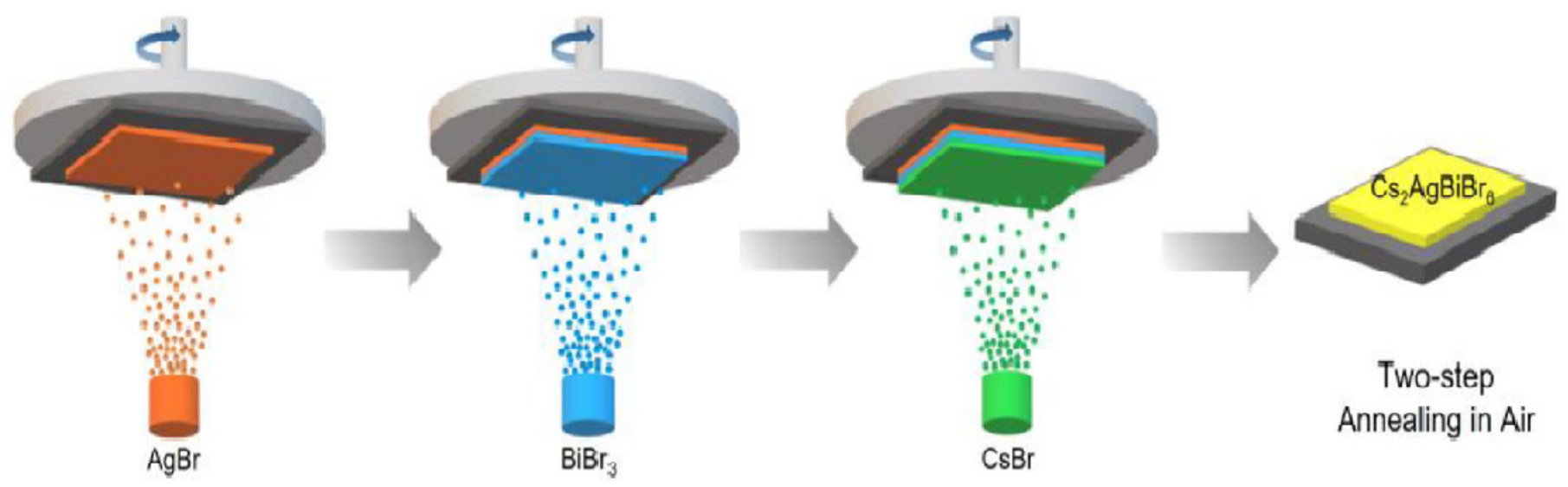

Figure 13. Scheme of sequential vapor deposition processing. Reproduced with permission from [82]. Copyright 2018, Wiley-VCH.

In 2019, Igbari et al. [83] selected two different synthesis methods of solution processing and vacuum processing for preparation of $\mathrm{Cs}_{2} \mathrm{AgBiBr}_{6}$ film as shown in Figure 14. The photophysical properties, electronic and crystalline structure as well as photovoltaic properties of the films were compared. The results of various characterizations demonstrated that $\mathrm{Cs}_{2} \mathrm{AgBiBr}_{6}$ film prepared by solution processing possessed higher crystallinity, longer charge carrier lifetime, narrower electronic bandgap of $1.98 \mathrm{eV}$ (2.08 eV for vacuum-processed film) and higher mobility compared with vacuum-processed $\mathrm{Cs}_{2} \mathrm{AgBiBr}_{6}$ film.

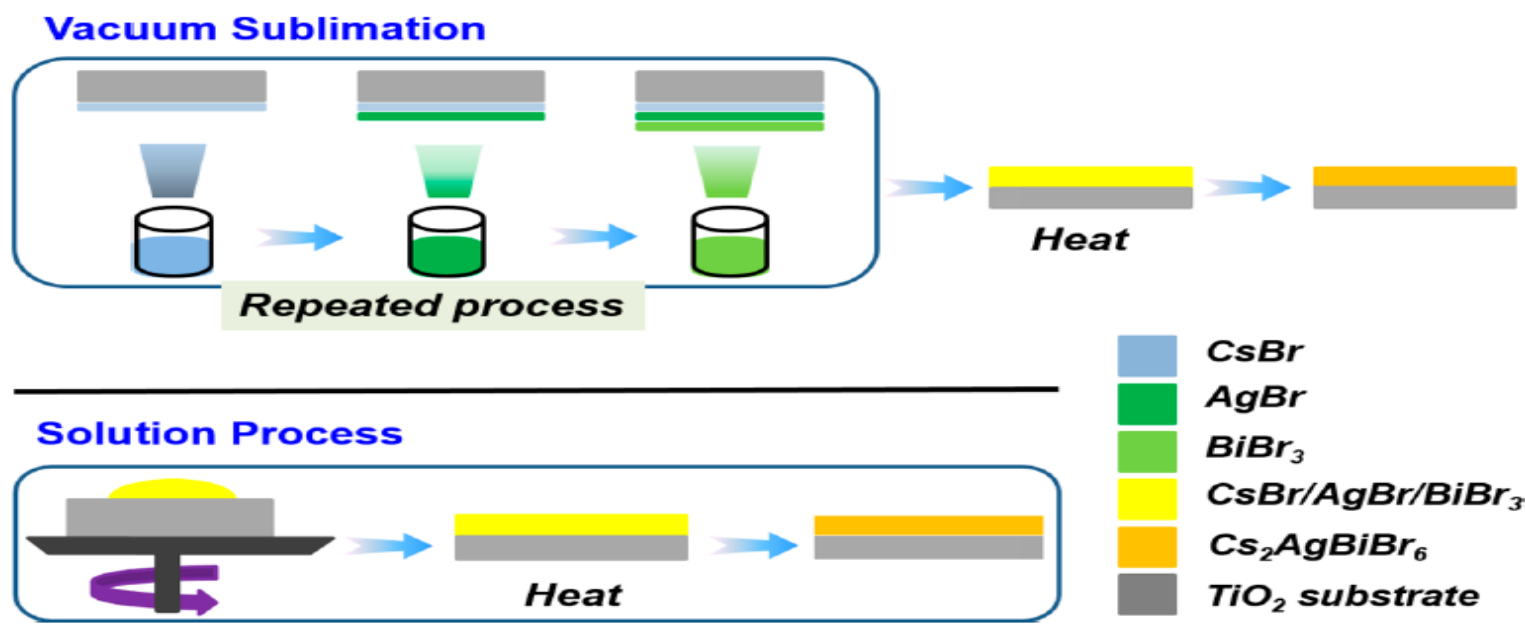

Figure 14. Preparation sketch of $\mathrm{Cs}_{2} \mathrm{AgBiBr}_{6}$ thin film through vacuum-sublimation and solution-processing. Reproduced with permission from [83]. Copyright 2019, American Chemical Society.

\subsection{3. $\mathrm{Cs}_{2} \mathrm{M}^{+} \mathrm{Bi}^{3+} \mathrm{X}_{6}$ : Doping}

Doping/alloying process is an effective method for tuning the electronic properties of the semiconducting materials [89]. For perovskite materials the partial of original constituent elements are replaced by targeted ions which leads to diverse advantages including, enhanced optoelectronic performance, stabilized crystal structure, improvement in photoluminescence properties, etc. [90]. A variety of doped $\mathrm{Cs}_{2} \mathrm{M}^{+} \mathrm{Bi}^{3+} \mathrm{X}_{6}$ structures are reviewed and listed in Table 3. In 2017, Slavney et al. [91] engineered $\mathrm{Cs}_{2} \mathrm{AgBiBr}_{6} \mathrm{double}$ halide perovskite's bandgap by dilute alloying $\mathrm{Tl}^{+}\left(\mathrm{Cs}_{2}\left(\mathrm{Ag}_{1-\mathrm{a}} \mathrm{Bi}_{1-\mathrm{b}}\right) \mathrm{Tl}_{\mathrm{x}} \mathrm{Br}_{6} ; 0.003<\mathrm{x}=\mathrm{a}\right.$ $+\mathrm{b}<0.075)$. DFT-PBE+SOC calculations showed that when $\mathrm{Ag}^{+}$was substituted by $\mathrm{Tl}^{+}$ $(x=0.06)$, the bandgap would decrease by $0.1 \mathrm{eV}$ with direct transition, while replacing 
the $\mathrm{Bi}^{3+}$ with $\mathrm{Tl}^{3+}(\mathrm{x}=0.06)$ would lower the bandgap by $0.8 \mathrm{eV}$ and transition would be indirect. Also, doping of $0.075 \mathrm{Tl}$ in $\left(\mathrm{Cs}_{2}\left(\mathrm{Ag}_{1-\mathrm{a}} \mathrm{Bi}_{1-\mathrm{b}}\right) \mathrm{Tl}_{\mathrm{x}} \mathrm{Br}_{6}\right.$ structure decreased the bandgap to $1.40 \mathrm{eV}$ (indirect) or to $1.57 \mathrm{eV}$ (direct). Importantly, the long-lived carrier lifetime in microsecond obtained by time-resolved microwave photoconductivity (TRMC), suggested the efficient extraction of carriers in a solar cell. Both bandgap and carrier lifetime of $\mathrm{Cs}_{2}\left(\mathrm{Ag}_{1-\mathrm{a}} \mathrm{Bi}_{1-\mathrm{b}}\right) \mathrm{Tl}_{\mathrm{x}} \mathrm{Br}_{6}$ structure were comparable to $\mathrm{MAPbI}_{3}$ values, but the real setback is that as known $\mathrm{Tl}^{+}$is toxic.

Du et al. [92] through alloying of $\mathrm{Sb}^{3+} / \mathrm{In}^{3+}$ in $\mathrm{Cs}_{2} \mathrm{AgBiBr}_{6}$ perovskite structure, engineered the bandgap and demonstrated long carrier recombination lifetime. Based on UV-vis diffuse spectra, it was shown that by replacing $\mathrm{Bi}^{3+}$ with $\mathrm{In}^{3+}$, when the level of alloyed metal $(\mathrm{x})$ reach to $0.75\left(\mathrm{Cs}_{2} \mathrm{AgBi}_{1-\mathrm{x}} \mathrm{In}_{\mathrm{x}} \mathrm{Br}_{6}\right)$, the indirect bandgap would increase to $2.27 \mathrm{eV}$. On the contrary, substitution of $\mathrm{Bi}^{3+}$ with $\mathrm{Sb}^{3+}$ up to $0.375\left(\mathrm{Cs}_{2} \mathrm{AgBi}_{1-\mathrm{x}} \mathrm{Sb}_{\mathrm{x}} \mathrm{Br}_{6}\right.$; $\mathrm{x}=0.375$ ), resulted in narrowing the bandgap from $2.12 \mathrm{eV}$ to $1.86 \mathrm{eV}$. The opposite bandgap shift direction was related to the different atomic configuration for these metals. The weak PL intensity of In-alloyed sample with high content $(x=0.75)$ was associated to deeper defect state and symmetry-forbidden transition from valence band to conduction band. Similarly, deep defect state of $\mathrm{Sb}^{3+}$-alloyed sample was responsible for the quickly suppressed emission intensity (Figure 15a-d).
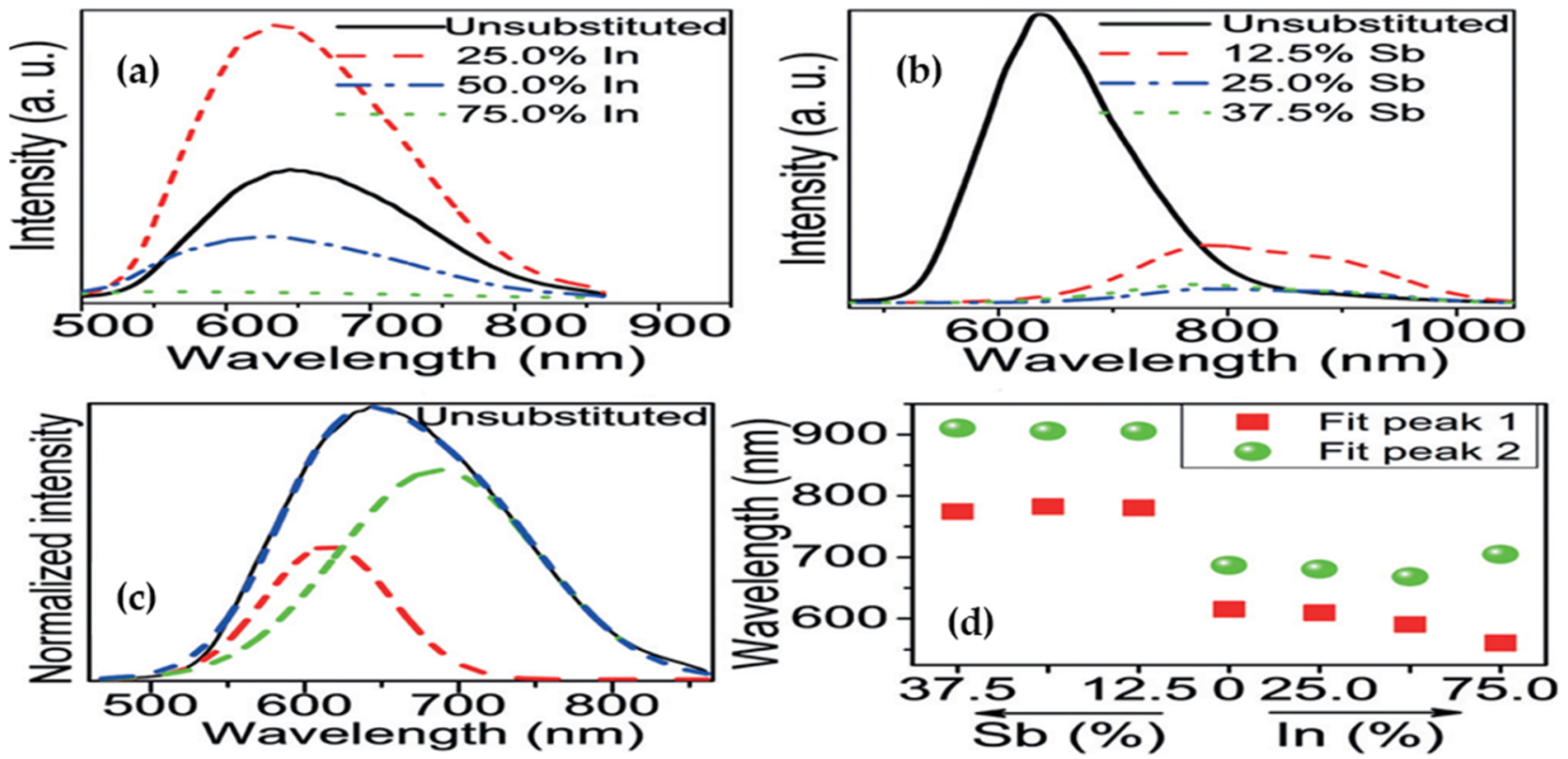

Figure 15. PL spectra for (a) In-alloyed; (b) Sb-alloyed samples; (c) for $\mathrm{Cs}_{2} \mathrm{AgBiBr}_{6}$, fitted using a Gaussian function. Red: fit peak 1, green: fit peak 2, blue dashed line: cumulative fit peak. (d) Fitted PL peak positions as a function of Sb and In alloying ratio. Reproduced with permission from [92]. Copyright 2017, Wiley-VCH. 
Table 3. Summary of prepared doped- Cs-based double halide perovskite samples.

\begin{tabular}{|c|c|c|c|c|c|}
\hline Compound & Dopant & Morphology & Synthetic Method & $\begin{array}{c}\text { Characterization } \\
\text { Techniques }\end{array}$ & Reference \\
\hline $\begin{array}{c}\mathrm{Cs}_{2}\left(\mathrm{Ag}_{1-\mathrm{a}} \mathrm{Bi}_{1-\mathrm{b}}\right) \\
\mathrm{Tl}_{\mathrm{x}} \mathrm{Br}_{6}\end{array}$ & $\begin{array}{c}\mathrm{Tl}^{+}(0.003<\mathrm{x}< \\
0.075)\end{array}$ & $\begin{array}{c}\text { Polycrystalline } \\
\text { Powder and single } \\
\text { crystals }\end{array}$ & $\begin{array}{l}\text { Solution-based } \\
\text { process using } \\
\text { hydrohalic acid }\end{array}$ & $\begin{array}{c}\text { TRMC, ICP, Raman, SSRS, } \\
\text { XPS, XAS, XANES, } \\
\text { SC-XRD, }\end{array}$ & [91] \\
\hline $\begin{array}{c}\mathrm{Cs}_{2} \mathrm{Ag}\left(\mathrm{Bi}_{1-\mathrm{x}} \mathrm{M}_{\mathrm{x}}\right) \\
\mathrm{Br}_{6}(\mathrm{M}=\mathrm{In}, \mathrm{Sb})\end{array}$ & $\begin{array}{l}\mathrm{Sb}^{3+}(\mathrm{x}=0,0.125 \\
\quad \text { and } 0.375) \\
\mathrm{In}^{3+}(\mathrm{x}=0,0.25,0.5 \\
\quad \text { and } 0.75)\end{array}$ & Powder & Solid-state reaction & $\begin{array}{l}\text { PXRD, PL, UV-Vis } \\
\text { spectroscopy }\end{array}$ & [92] \\
\hline $\mathrm{Cs}_{2} \mathrm{AgIn}_{\mathrm{x}} \mathrm{Bi}_{1-\mathrm{x}} \mathrm{Cl}_{6}$ & $\begin{array}{l}\mathrm{In}^{3+}(\mathrm{x}=0,0.25,0.5 \\
0.75, \text { and } 0.9)\end{array}$ & Nanocrystals & $\begin{array}{l}\text { Anti-solvent } \\
\text { recrystallization }\end{array}$ & $\begin{array}{c}\text { XRD, TEM, PL, PLQE, } \\
\text { HRTEM, TRPL, TCSPC, } \\
\text { TA, XPS }\end{array}$ & [93] \\
\hline $\begin{array}{l}\mathrm{Cs}_{2} \mathrm{Na}_{1-x} \mathrm{Bi}_{1-\mathrm{x}} \\
\mathrm{Mn}_{2 \mathrm{x}} \mathrm{Cl}_{6}\end{array}$ & $\begin{array}{l}\mathrm{Mn}^{2+}(\mathrm{x}=0,0.002 \\
0.004,0.012,0.036)\end{array}$ & Polycrystalline & $\begin{array}{l}\text { Solution } \\
\text { precipitation }\end{array}$ & $\begin{array}{c}\text { PXRD, UV-Vis } \\
\text { spectroscopy, EPR, PLQY, } \\
\text { TGA, ICP-OES }\end{array}$ & [94] \\
\hline$\left(\mathrm{Cs}_{1-\mathrm{x}} \mathrm{Rb}_{\mathrm{x}}\right)_{2} \mathrm{AgBiBr}_{6}$ & $\begin{array}{l}\text { CsBr:RbBr at 100:0, } \\
95: 5,90: 10 \text { and 85:15 }\end{array}$ & Thin film & $\begin{array}{l}\text { Solution-based } \\
\text { process }\end{array}$ & $\begin{array}{l}\text { UV-Vis spectroscopy, XRD, } \\
\text { PL, IPEC, TRPL, SEM }\end{array}$ & [84] \\
\hline $\begin{array}{l}\mathrm{Cs}_{2} \mathrm{NaBiCl}_{6}: \mathrm{Ag}^{+} \\
\mathrm{Mn}^{2+}, \text { and } \mathrm{Eu}^{3+}\end{array}$ & $\mathrm{Ag}^{+}, \mathrm{Mn}^{2+}$, and $\mathrm{Eu}^{3+}$ & Nanocrystals & $\begin{array}{l}\text { Modified } \\
\text { hot-injection } \\
\text { method }\end{array}$ & $\begin{array}{l}\text { PXRD, TEM, HRTEM, } \\
\text { HAADF-STEM, EDS, XPS, } \\
\text { UV-Vis spectroscopy, } \\
\text { PLQY, ICP-OES, }\end{array}$ & [95] \\
\hline $\mathrm{Cs}_{2} \mathrm{AgInCl}_{6}: \mathrm{Mn}^{2+}$ & $\begin{array}{l}\mathrm{Mn}^{2+}(\mathrm{x}=0 \%, 0.1 \% \\
0.3 \%, 0.9 \%)\end{array}$ & Powder & $\begin{array}{l}\text { Solution-based } \\
\text { process using } \\
\text { hydrohalic acid }\end{array}$ & $\begin{array}{c}\text { ICP-AES, FESEM, XRD, } \\
\text { TGA, PL, EPR, } \\
\text { UV-Vis.spectroscopy, } \\
\text { PL, PLE, PLQY, TRPL, }\end{array}$ & [96] \\
\hline $\mathrm{Cs}_{2} \mathrm{AgInCl}_{6}: \mathrm{Mn}^{2+}$ & $\begin{array}{c}\mathrm{Mn}^{2+}(\mathrm{x}=0.5 \% \text { and } \\
1.5 \%)\end{array}$ & Nanocrystals & $\begin{array}{l}\text { Colloidal } \\
\text { hot-injection } \\
\text { method }\end{array}$ & $\begin{array}{c}\text { ICP-OES, UV-Vis } \\
\text { spectroscopy, TEM, } \\
\text { HRTEM, XRD, XPS, ESR, } \\
\text { DTA/TG GC-MS }\end{array}$ & [97] \\
\hline $\begin{array}{l}\mathrm{Cs}_{2} \mathrm{Ag}_{1-\mathrm{x}} \mathrm{Na}_{\mathrm{x}} \\
\mathrm{In}_{1-\mathrm{y}} \mathrm{Bi}_{\mathrm{y}} \mathrm{Cl}_{6}\end{array}$ & $\begin{array}{c}\mathrm{Bi}^{3+} \text { and } \mathrm{Na}^{1+} \\
(\mathrm{x}=0-1, \mathrm{y}= \\
0.03-0.16)\end{array}$ & Nanocrystals & $\begin{array}{l}\text { Room temperature } \\
\text { recrystallization } \\
\text { process }\end{array}$ & $\begin{array}{l}\text { UV-Vis spectroscopy, TEM, } \\
\text { HRTEM, XRD, ICP-OES, } \\
\text { PLQY, PL, SEM-EDS, }\end{array}$ & [98] \\
\hline $\mathrm{Cs}_{2} \mathrm{AgInCl}_{6}: \mathrm{Bi}^{3+}$ & $\mathrm{Bi}^{3+}(\mathrm{x}=0.1 \%)$ & Nanocrystals & $\begin{array}{l}\text { Facile hot-injection } \\
\text { method }\end{array}$ & $\begin{array}{c}\text { XRD, EDS, TEM, HRTEM, } \\
\text { UV-Vis spectroscopy, PL, } \\
\text { PLE, PLQY }\end{array}$ & [99] \\
\hline $\mathrm{Cs}_{2} \mathrm{AgInCl}_{6}: \mathrm{Yb}^{3+}$ & $\mathrm{Yb}^{3+}(\mathrm{x}=0.1$ to $1.6 \%)$ & $\begin{array}{l}\text { Microcrystals and } \\
\text { Colloidal } \\
\text { nanocrystals }\end{array}$ & $\begin{array}{l}\text { Precipitation } \\
\text { method }\end{array}$ & $\begin{array}{c}\text { ICP-AES, ICP-MS, XRD, } \\
\text { FESEM, TEM, HRTEM, } \\
\text { PL, PLE, TRPL, UV-Vis } \\
\text { spectroscopy, TGA, }\end{array}$ & [100] \\
\hline $\mathrm{Cs}_{2} \mathrm{NaInCl}_{6}: \mathrm{Sb}^{3+}$ & $\begin{array}{l}\mathrm{Sb}^{3+} / \mathrm{In}^{3+}(\mathrm{x}=0 \\
5.0 \%, 10 \%, 20 \%)\end{array}$ & Powder & $\begin{array}{l}\text { precipitation from } \\
\text { an } \mathrm{HCl} \text { solution }\end{array}$ & $\begin{array}{c}\text { PXRD, TGA, UV-Vis } \\
\text { spectroscopy, PLQY, PL, }\end{array}$ & [101] \\
\hline $\mathrm{Cs}_{2} \mathrm{NaInCl}_{6}: \mathrm{Sb}^{3+}$ & $\begin{array}{c}(\mathrm{Sb} /(\mathrm{Sb}+\mathrm{In})(\mathrm{x}=0 \\
5.0 \%, 10 \%, 15 \%, 30 \% \\
60 \%, 100 \%)\end{array}$ & Powder & Hydrotermal & $\begin{array}{l}\text { XRD, UV-Vis spectroscopy, } \\
\text { PL, TEM, XPS, PLE, } \\
\text { HRTEM, Raman }\end{array}$ & [102] \\
\hline $\begin{array}{c}\mathrm{Cs}_{2} \mathrm{Sb}_{1-\mathrm{a}} \mathrm{Ag}_{1-\mathrm{b}} \\
\mathrm{Cu}_{2 \mathrm{x}} \mathrm{Cl}_{6}\end{array}$ & $\begin{array}{c}\mathrm{Cu}^{2+}(\mathrm{a}+\mathrm{b}=2 \mathrm{x}, \mathrm{x}= \\
0.00 \text { (i.e., parent } \\
\text { compound), } 0.01 \\
0.05 \text {, and } 0.10)\end{array}$ & Polycrytalline & $\begin{array}{l}\text { precipitation from } \\
\text { an } \mathrm{HCl} \text { solution }\end{array}$ & $\begin{array}{c}\text { PXRD, EPR, NMR, } \\
\text { ICP-OES, TGA, FESEM }\end{array}$ & [103] \\
\hline $\mathrm{Cs}_{2} \mathrm{AgSb}_{1-\mathrm{x}} \mathrm{Bi}_{\mathrm{x}} \mathrm{Cl}_{6}$ & $\mathrm{Bi}^{3+}(0 \leq \mathrm{x} \leq 1)$ & Nanocrytals & $\begin{array}{l}\text { Modified } \\
\text { hot-injection } \\
\text { method }\end{array}$ & $\begin{array}{c}\text { XRD, FESEM, EDS, TEM, } \\
\text { HRTEM, PL, PLE, UV-Vis } \\
\text { spectroscopy, }\end{array}$ & [104] \\
\hline $\begin{array}{c}\mathrm{Cs}_{2} \mathrm{AgSb}_{1-y} \mathrm{Bi}_{y} \mathrm{X}_{6} \\
(\mathrm{X}=\mathrm{Br}, \mathrm{Cl})\end{array}$ & $\mathrm{Bi}^{3+}(0 \leq \mathrm{y} \leq 1)$ & Nanocrytals & $\begin{array}{l}\text { Modified } \\
\text { hot-injection } \\
\text { method }\end{array}$ & $\begin{array}{l}\text { XRD, TEM, PL, Raman, } \\
\text { TA, steady-state } \\
\text { absorption }\end{array}$ & [105] \\
\hline $\mathrm{Cs}_{2} \mathrm{Sn}_{1-\mathrm{x}} \mathrm{Te}_{\mathrm{x}} \mathrm{I}$ & $\mathrm{Te}^{4+}(0 \leq \mathrm{x} \leq 1)$ & Powder & $\begin{array}{l}\text { Solution-phase } \\
\text { synthesis }\end{array}$ & $\begin{array}{c}\text { PXRD, UV-Vis } \\
\text { spectroscopy, PL, XPS }\end{array}$ & [106] \\
\hline $\mathrm{Cs}_{2} \mathrm{SnCl}_{6}: \mathrm{Bi}$ & $\begin{array}{c}\mathrm{Bi} /(\mathrm{Sn}+\mathrm{Bi}) \times=0 \%, \\
0.99 \%, 4.76 \%, 9.09 \%, \\
13.04 \%, 16.66 \% \text {, and } \\
23.08 \%\end{array}$ & Single crystals & Hydrothermal & $\begin{array}{l}\text { XRD, ICP-OES, XPS, TGA, } \\
\text { UV-Vis spectroscopy, PL, } \\
\text { PLQY, PLE, TRPL }\end{array}$ & [107] \\
\hline $\mathrm{Cs}_{2} \mathrm{Sn}_{(1-\mathrm{x})} \mathrm{Ge}_{\mathrm{x}} \mathrm{I}_{6}$ & $\mathrm{Ge}^{4+}(0 \leq \mathrm{x} \leq 1)$ & - & & - & [108] \\
\hline
\end{tabular}


$\mathrm{Cs}_{2} \mathrm{AgBi}_{1-\mathrm{x}} \mathrm{In}_{\mathrm{x}} \mathrm{Cl}_{6}(\mathrm{x}=0,0.25,0.5,0.75$ and 0.9$) \mathrm{NCs}$ were prepared by Yang et al. [93], through anti solvent recrystallization. In this work, $\mathrm{Cs}_{2} \mathrm{AgBi}_{1-\mathrm{x}} \mathrm{In}_{\mathrm{x}} \mathrm{Cl}_{6}(\mathrm{x}=0.25,0.5)$ with indirect bandgap were tuned to direct band gap by increasing the $\mathrm{In}^{3+}$ content to 0.75 and 0.9. DFT calculation along with steady-state absorption, PL and transient absorption spectra measurements demonstrated dual color emission of violet $(395 \mathrm{~nm}$ ) (band to band transition) and bright orange $(570 \mathrm{~nm})$ (forbidden transition) in NCs.

In 2019, $\mathrm{Mn}^{2+}$ doped $\mathrm{Cs}_{2} \mathrm{NaBiCl}_{6}$ polycrystalline as a promising orange-red phosphor system was reported by Majher et al. [94]. The absorbed near-UV light by $\mathrm{Bi}^{3+}$ ions in the host lattice transferred to $\mathrm{Mn}^{2+}$ activators and through the spin-forbidden ${ }^{4} \mathrm{~T}_{1} \rightarrow{ }^{6} \mathrm{~A}_{1}$ transition, light emitting from 525 to $700 \mathrm{~nm}$ occurred. Also, they [94] demonstrated partial substitution of $\mathrm{Cl}^{-}$ions by $\mathrm{Br}^{-}$resulted in redshift of exciton spectra as well as an optical absorption peak. Zhang et al. [84], through doping of different amount of $\mathrm{Rb}^{+}$ion by replacing $\mathrm{Cs}^{+}$(stochiometric ratio of $\mathrm{Cs}^{+} / \mathrm{Rb}^{+}: 100 / 0,95 / 5,90 / 10,85 / 15$ ) prepared different $\left(\mathrm{Cs}_{1-\mathrm{x}} \mathrm{Rb}_{\mathrm{x}}\right)_{2} \mathrm{AgBiBr}{ }_{6}$ perovskite compounds. Optical measurements showed with doping ratio of $\mathrm{Cs}^{+} / \mathrm{Rb}^{+}: 90: 10$, the intensity of PL spectra increased due to the reduction of defects. Moreover, based on IPEC spectrum, it was shown that doping of $\mathrm{Rb}^{+}$ion leads in enhancement of absorption at longer wavelength as depicted in Figure 16a-c.

(a)

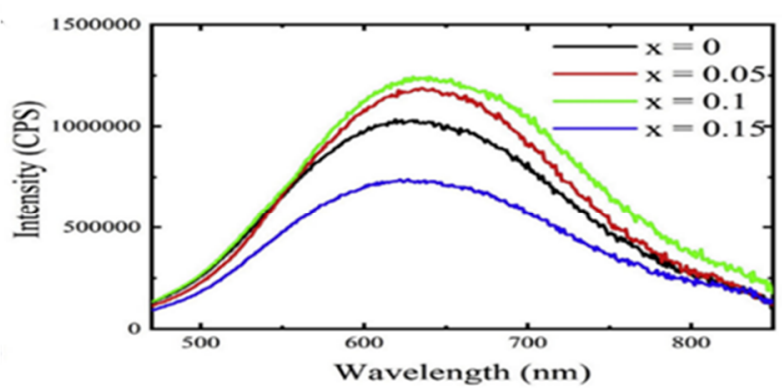

(b)

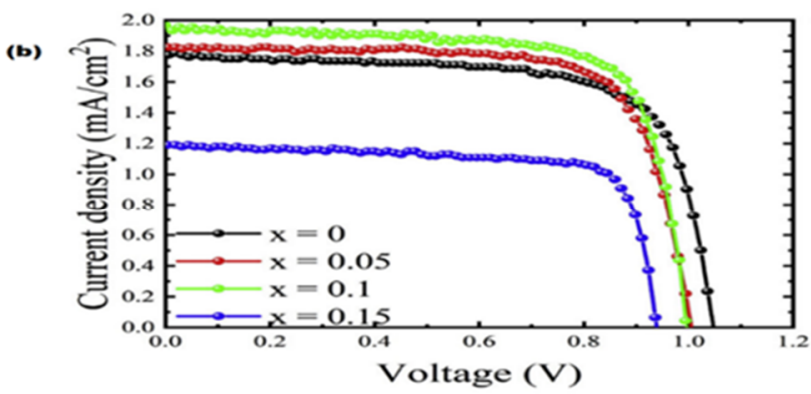

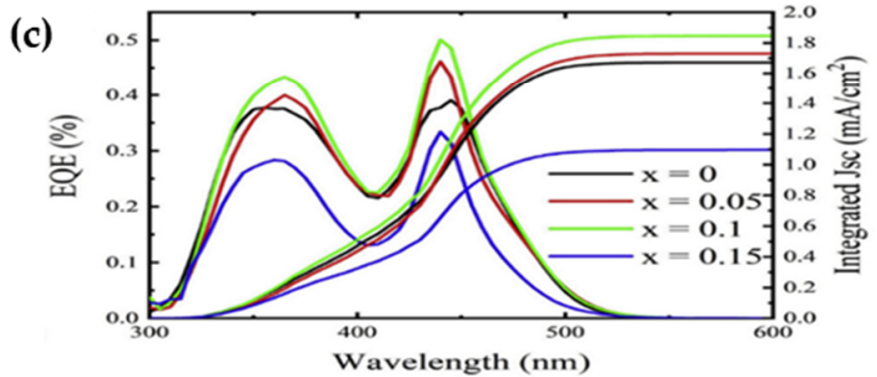

Figure 16. (a) The PL spectra of $\left(\mathrm{Cs}_{1-\mathrm{x}} \mathrm{Rb}_{\mathrm{x}}\right)_{2} \mathrm{AgBi}$ films on quartz; (b) The J-V curves of the champion devices with $\left(\mathrm{Cs}_{1-\mathrm{x}} \mathrm{Rb}_{\mathrm{x}}\right)_{2} \mathrm{AgBi}_{6}$ and (c) the EQE and IPEC of the devices. Reproduced with permission from [84]. Copyright 2019, Elsevier.

In 2020, Yao et al. [95] reported studies on lead-free double halide perovskite $\mathrm{Cs}_{2} \mathrm{NaBiCl}_{6} \mathrm{NCs}$ as host, doped with $\mathrm{Ag}^{+}, \mathrm{Mn}^{2+}, \mathrm{Eu}^{3+}$ ions through hot-injection approach in order to improve the optical properties of the material. The femtosecond time-resolved transient absorption technique was utilized to investigate the PL enhancement mechanism of ion doped NCs. The excitonic absorption energy of Ag-doped sample exhibited red-shift from $3.82 \mathrm{eV}$ to $3.48 \mathrm{eV}$ which led to significant increase of PLQY from $1.7 \%$ to

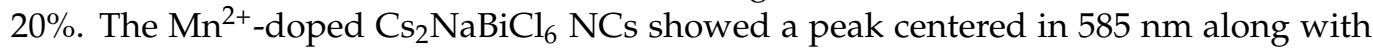
broad red-orange emission owing to ${ }^{4} \mathrm{~T}_{1} \rightarrow{ }^{6} \mathrm{~A}_{1}$ transition of coordinated $\mathrm{Mn}^{2+}$ ions. Also, $\mathrm{Eu}^{3+}$-doped NCs, owing to the ${ }^{5} \mathrm{D}_{0} \rightarrow{ }^{7} \mathrm{~F}_{\mathrm{J}}(\mathrm{J}=1,2,3,4)$ transition, demonstrated four sharp emission lines at PL spectra corresponding to 591, 615, 652 and $700 \mathrm{~nm}$, respectively. 


\subsection{4. $\mathrm{Cs}_{2} \mathrm{M}^{+} \mathrm{Bi}^{3+} \mathrm{X}_{6}$ : Applications}

\section{- Photovoltaic Applications}

As presented in Table 2, in 2017, Greul et al. [77] fabricated for the first time the $\mathrm{Cs}_{2} \mathrm{AgBiBr}_{6}$-based PSC, which after different parameter measurements exhibited power conversion efficiency (PECs) of $2.43 \%$ with $\mathrm{V}_{\mathrm{oc}}$ exceeding 1 Volt as well as higher stability under constant illumination in ambient environment compared to $\mathrm{MAPBI}_{3}$. In another study, Wu et al. [78] fabricated a PSC with $\mathrm{Cs}_{2} \mathrm{AgBiBr}_{6}$ film as active absorbing layer with a PCE of $1.44 \%$ and $\mathrm{V}_{\mathrm{oc}}$ of $1.04 \mathrm{~V}, \mathrm{~J}_{\mathrm{sc}}$ of $1.78 \mathrm{~mA} \mathrm{~cm}{ }^{-2}$ and FF of 78 under AM1.5 $\left(100 \mathrm{~mW} \mathrm{~cm}^{-2}\right)$ illumination. The low PCE of the device was attributed to larger exciton binding energy of $\mathrm{Cs}_{2} \mathrm{AgBiBr}_{6}$ than $\mathrm{MAPbI}_{3}$. However, the Hole Transporting Layer (HTL)-free device showed higher stability in 4 months compared to $\mathrm{MAPbI}_{3}$ based PSCs.

In 2018, Ning et al. [79] demonstrated the $\mathrm{Cs}_{2} \mathrm{AgBiBr}_{6}$ solar cell using one-step spin coating process from single-crystal $\mathrm{Cs}_{2} \mathrm{AgBiBr}_{6}$ solution. The device showed a PCE with maximum value of $1.22 \%$ and long photoexcited carrier diffusion length close to $110 \mathrm{~nm}$. The $\mathrm{V}_{\mathrm{oc}}$ of $1.06 \mathrm{~V}, \mathrm{~J}_{\mathrm{sc}}$ of $1.55 \mathrm{~mA} \mathrm{~cm}{ }^{-2}$ and FF of 74 were also achieved for the device. The low PCE value was attributed to the low efficiency of charge extraction by $\mathrm{TiO}_{2}$ as the electron transporting layer (ETL) as well as presence of interfacial barrier due to the surface defects. They predicated by increasing the film thickness while preserving the quality of the absorber film and replacing the $\mathrm{TiO}_{2}$ by other suitable ETL materials the efficiency of Bi-based halide double perovskite solar cells could be enhanced. Gao et al. [81] adopted anti-solvent dropping methodology for synthesis of $\mathrm{Cs}_{2} \mathrm{AgBiBr}_{6}$ film as already shown in Figure 11a,b. The inverted planer heterojunction fabricated device showed PCE of $2.23 \%$ with $\mathrm{V}_{\mathrm{oc}}$ of $1.01 \mathrm{~V}, \mathrm{~J}_{\mathrm{sc}}$ of $3.19 \mathrm{~mA} \mathrm{~cm}^{-2}$ and FF of 69.2 at forward scan as already depicted in Figure 11d,e. The device also showed good reproducibility, negligible hysteresis and long-term stability. Pantaler et al. [80] reported a hysteresis-free solar device using $\mathrm{Cs}_{2} \mathrm{AgBiBr}_{6}$ film as an absorbing layer. In this work, they separately employed three different semiconducting polymers as HTL layer. The best result among different HTL-based devices including spiro-OMeTAD, PCPDTBT (Poly [2,6-(4,4-bis-(2-ethylhexyl)4H-cyclopenta[2,1-b;3,4- $\mathrm{b}^{\prime}$ ]dithiophene)alt4,7(2,1,3-benzothiadiazole)]) and PTAA poly [bis(4-phenyl)(2,4,6-trimethylphenyl)amine), was obtained for PTTA HTL-based device with $1.26 \%$ of PCE, $1.02 \mathrm{~V}$ of $\mathrm{V}_{\mathrm{oc}}$ and $1.84 \mathrm{~mA} \mathrm{~cm}^{-2}$ of $\mathrm{J}_{\mathrm{sc}}$ with $\mathrm{FF}$ of 67.

In 2018, Zhang et al. [75] replaced $\mathrm{Ag}^{+}$in $\mathrm{Cs}_{2} \mathrm{AgBiBr}_{6}$ double halide perovskite with $\mathrm{Na}^{+}$ion in order to fabricate the solar device. $\mathrm{Cs}_{2} \mathrm{NaBiI}_{6}$ perovskite was prepared by facile one-step hydrothermal process. However, the fabricated device demonstrated low $\mathrm{J}_{\mathrm{sc}}$ due to two main reasons, namely that $\mathrm{Cs}_{2} \mathrm{NaBiI}_{6}$ perovskite had (1) low hole transport ability, and (2) was not able to efficiently convert the excitons to current. Nevertheless, the fabricated devices showed high stability for 5 months. Testing of a batch of 20 different devices showed the PCE of $0.42 \%$ with $\mathrm{V}_{\mathrm{oc}}$ of $0.47 \mathrm{~V}, \mathrm{~J}_{\mathrm{sc}}$ of $1.99 \mathrm{~mA} \mathrm{~cm}{ }^{-2}$ and FF of 44 . Wang et al. [82] fabricated a PSC by employing sequential-vapor-deposition procedure for synthesis of active layer $\mathrm{Cs}_{2} \mathrm{AgBiBr}_{6}$ film as already showed in Figure 13. The device showed lower defect density compered to $\mathrm{Cs}_{2} \mathrm{AgBiBr}_{6}$ film prepared by solution process as well as good stability after $240 \mathrm{~h}$ under ambient environment. The PCE of $1.37 \%$ and $\mathrm{V}_{\mathrm{oc}}$ of $1.12 \mathrm{~V}$ were reported. By employing solution-based processing and vacuum sublimation method, Igbari et al. [83] could achieve an optimized PCE of $2.51 \%$ and $1.41 \%$, respectively for $\mathrm{Cs}_{2} \mathrm{AgBiBr}_{6}$-based PSCs.

In 2020, Wang et al. [64] studied the performance of Zinc chlorophyll (Zn-Chl) as the HTL in $\mathrm{Cs}_{2} \mathrm{AgBiBr}_{6}$-based PSC. It was shown that by employing the $\mathrm{Zn}$-Chl not only enhanced the photovoltaic performance was achieved but also the light absorbing abilities of the $\mathrm{Cs}_{2} \mathrm{AgBiBr}_{6}$ through the sensitizing of the perovskite material was improved. The PSCs based on Zn-Chl showed PCE of $2.79 \%$ with $\mathrm{V}_{\text {oc }}$ of $0.99 \mathrm{~V}, \mathrm{~J}_{\mathrm{sc}}$ of $3.83 \mathrm{~mA} \mathrm{~cm}{ }^{-2}$ and FF of 73.6. In another study in 2020, Yang et al. [65] demonstrated that by employing di-tetrabutylammonium cis-bis(isothiocyanato) bis (2,2'-bipyridyl-4, $4^{\prime}$ dicarboxylato) ruthenium (II) (N719) dye as an interlayer on the surface of $\mathrm{Cs}_{2} \mathrm{AgBiBr}_{6}$ film, the efficiency and stability of $\mathrm{Cs}_{2} \mathrm{AgBiBr}_{6}$-based solar device were boosted. Applying the N719, also led 
to broadening the light absorption spectrum, reducing the charge carrier recombination, reducing the $\mathrm{Cs}_{2} \mathrm{AgBiBr}_{6}$ film surface defects and accelerating the hole extraction. The optimized solar device showed PCE of $2.84 \%$ with $\mathrm{V}_{\mathrm{oc}}$ of $1.06 \mathrm{~V}$, $\mathrm{J}_{\mathrm{sc}}$ of $5.13 \mathrm{~mA} \mathrm{~cm}{ }^{-2}$ and FF of 52.4 .

In 2021, Wang et al. [66] following their previous work [64], by employing carboxychlorophyll derivative $(\mathrm{C}-\mathrm{Chl})$ in the mesoporous $\mathrm{TiO}_{2}$ film, improved the efficiency of $\mathrm{Cs}_{2} \mathrm{AgBiBr}_{6}$-based solar cells to more than $3 \%$, which is the highest reported efficiency for $\mathrm{Cs}_{2} \mathrm{AgBiBr}_{6}$ PSC. The fabricated PSC based on C-Chl- sensitized mesoporous $\mathrm{TiO}_{2}$ film showed improved PCE of $3.11 \%$ with $\mathrm{V}_{\mathrm{oc}}$ of $1.04 \mathrm{~V}$, $\mathrm{J}_{\mathrm{sc}}$ of $4.09 \mathrm{~mA} \mathrm{~cm}^{-2}$, and FF of 73 .

As summarized in this section, $\mathrm{Cs}_{2} \mathrm{AgBiBr}_{6}$-based solar cells have showed low power conversion efficiency compared to lead-based PSCs. However, the results obtained show clearly that $\mathrm{Cs}_{2} \mathrm{AgBiBr}_{6}$ is a promising material for $\mathrm{PV}$ application even though the path to enhance the efficiency might be long. The aforementioned studies $[77-79,82,84]$ show that employing of a variety of coating engineering such as using Low-pressure assisted method (LPA), anti-solvent method, vapor deposition method and introducing metal ion dopants resulted in enhanced $\mathrm{Cs}_{2} \mathrm{AgBiBr}_{6}$ film morphology improving the efficiency. Furthermore, it was shown that modifying and optimizing ETL and HTL layers also have a significant impact on improvement of efficiency of $\mathrm{Cs}_{2} \mathrm{AgBiBr}_{6}$-based solar cells $[64,66]$.

To increase the fill factor $(\mathrm{FF})$ and the open source voltage $\left(\mathrm{V}_{\mathrm{oc}}\right)$, the recombination has to be controlled. It is needed to obtain uniform and high-crystalline perovskite films; meaning that the defect density of the perovskite layer should be reduced [109]. In another words, the higher density traps of the perovskite film cause in more Shockley-Read-Hall (SRH) recombination and lower FF and consequently lead to poor PCE. Wang et al. [66] Used a concept based on ideality factor $(N)$ in order to describe the SRH recombination due to defect density. $N$ is defined by:

$$
N=\frac{e}{K_{B} T} \frac{\mathrm{dV}_{\mathrm{oc}}}{\mathrm{d} \ln I}
$$

where $e$ is electron charge, $K_{B}$ is Boltzmann constant, $I$ is different light intensity, $T$ is the temperature and $N$ shows the charge carrier' recombination process. For ideal solar cells $N$ must approach unity. When $N$ approaches 2 , the performance of the device dominated by Shockley-Read-Hall (SRH) recombination which is assisted by defect density. Therefore, lower $N$ value shows suppression of SRH and reduced trap densities which results in higher fill factor and higher PCE [66].

\section{- Non-Photovoltaic Applications}

Volonakis et al. [110] adopted first-principle calculation to determine the level of surfaces and surface termination energy of $\mathrm{Cs}_{2} \mathrm{AgBiCl}_{6}, \mathrm{Cs}_{2} \mathrm{AgBiBr}_{6}, \mathrm{Cs}_{2} \mathrm{AgSbCl}_{6}$ and $\mathrm{Cs}_{2} \mathrm{AgInCl}_{6}$ double halide perovskites. Their investigation demonstrated that according to ionization potential and electron affinity, amongst all these four materials, $\mathrm{Cs}_{2} \mathrm{AgBiCl}_{6}$ and $\mathrm{Cs}_{2} \mathrm{AgBiBr}_{6}$ were the most promising photocatalysts for solar-driven water splitting. Their study also indicated, by increasing the size of halogens in double perovskites, the electron affinity would increase as well, which was due to the shallower energies of the halogen p-states. In 2017, Pan et al. [111] for the first time, reported the application of $\mathrm{Cs}_{2} \mathrm{AgBiBr}_{6}$ single crystals as $\mathrm{X}$-ray detectors. Using of thermal annealing and surface treatment resulted in elimination of disordered $\mathrm{Ag}^{+} / \mathrm{Bi}^{3+}$ and consequently, the resistivity of the crystals improved. The optimized device showed high sensitivity of $105 \mu \mathrm{C} \mathrm{Gyair}{ }^{-1} \mathrm{~cm}^{-2}$, low detection limit of $105 \mathrm{nC} \mathrm{Gyair}^{-1} \mathrm{~s}^{-1}$ under the external bias of $5 \mathrm{~V}$ as well as long-term operational stability which all are essential for X-ray detectors in order to medical diagnostics. The single crystals of $\mathrm{Cs}_{2} \mathrm{AgBiBr}_{6}$ as suitable semiconductor directly converted X-rays into electrical signals due to its high average atomic number which results in higher X-ray absorption coefficient $\left(\alpha \propto Z^{4} / E^{3}\right)$, adequate $\mu \tau$ product ( $\mu=$ carrier mobility; $\tau=$ carrier lifetime), low ionization energy and high resistivity. Yuan et al. [112] by introducing PEABr (phenylethylamine bromide) into the $\mathrm{Cs}_{2} \mathrm{AgBiBr}_{6}$ 
perovskite precursors solution, obtained single crystals of $\mathrm{Cs}_{2} \mathrm{AgBiBr}_{6}$ with enhanced ordering degree of $\left[\mathrm{BiX}_{6}\right]^{3-}$ and $\left[\mathrm{AgX}_{6}\right]^{5-}$ in octahedra arrangement. The improved order degree gave rise to lower defect density, tunable bandgap, decreased self-trapped exciton formation and increased carrier mobility. The $\mathrm{X}$-ray detector displayed higher current response of 13 vs. $3190 \mu \mathrm{s}$, higher sensitivity of $288.8 \mu \mathrm{C} \mathrm{Gy} \mathrm{air}^{-1} \mathrm{~cm}^{-2}$ under a bias of $50 \mu \mathrm{C} \mathrm{Gy}_{\text {air }}{ }^{-1} \mathrm{~cm}^{-2}$, higher photoconductive gain and longer carrier drift distance. $\mathrm{Li}$ et al. [113] synthesized composites films comprised of $\mathrm{Cs}_{2} \mathrm{AgBiBr}_{6}$ perovskite embedded in a polymer matrix by a simple drop-casting process. Hydroxyl functional groups of polymers significantly increased the dispersity of $\mathrm{Cs}_{2} \mathrm{AgBiBr}_{6}$ in the composite films which led in large area dense films. The fabricated X-ray detector obtained by the composite films demonstrated a sensitivity of $40 \mu \mathrm{C} \mathrm{Gy} \mathrm{air}^{-1} \mathrm{~cm}^{-2}$ under the external bias of $400 \mathrm{~V}$, and due to the maximum tolerance of $5 \%$ tensile/compressive strain, bending/flexing of detectors did not have any degrading effect on photocurrent.

Lei et al. [114] adopted a one-step spin-coating synthesis method for preparation of $\mathrm{Cs}_{2} \mathrm{AgBiBr}_{6}$ film as photodetector. The device showed high responsivity of $7.01 \mathrm{~A} / \mathrm{W}$, On/Off photocurrent ratio of $2.16 \times 10^{4}$, specific detectivity of $5.66 \times 10^{11}$ Jones, EQE of $2164 \%$, fast response speed of $956 / 995 \mu$ s. The other remarkable feature of unencapsulated photodetector was the high stability under ambient environment against water and oxygen degradation ( $36 \mathrm{~h}$ continuous operation) without no change in photodetection ability. Wu et al. [115] designed a HTL-free planer heterojunction device including ITO/ $\mathrm{SnO}_{2}$ / $\mathrm{Cs}_{2} \mathrm{AgBiBr}_{6} / \mathrm{Au}$ as ultraviolet (UV) photodetector as shown in Figure 17a,b. The selfpowered devices exhibited two responsivity peaks at $350 \mathrm{~nm}$ and $435 \mathrm{~nm}$ which was associated with ultraviolet-A (320-400 nm). The mechanism explained by separation of photogenerated carriers at the of interface of $\mathrm{Cs}_{2} \mathrm{AgBiBr}_{6} / \mathrm{SnO}_{2}$ heterojunction by its built-in field. A high responsivity of $0.11 \mathrm{~A} \mathrm{~W}^{-1}$ at $350 \mathrm{~nm}$ and the quick response of less than $3 \mathrm{~ms}$ was comparable with other semiconductor oxide heterojunction-based UV detectors. The unencapsulated UV detector also showed remarkable stability under ambient environment for more than 6 months without any noticeable degradation in photocurrent.

(a)

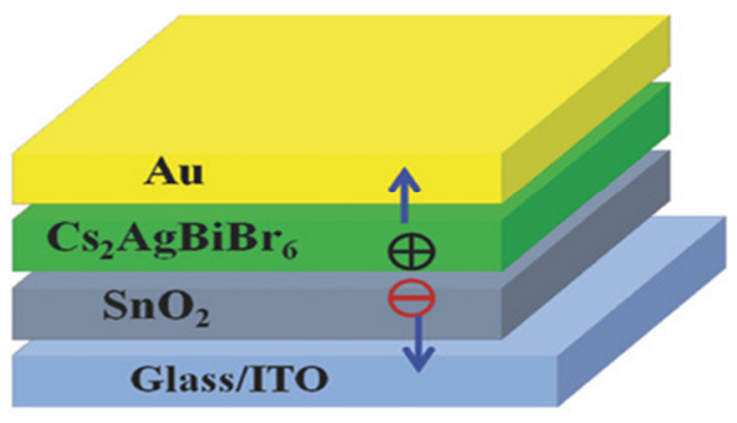

(b)

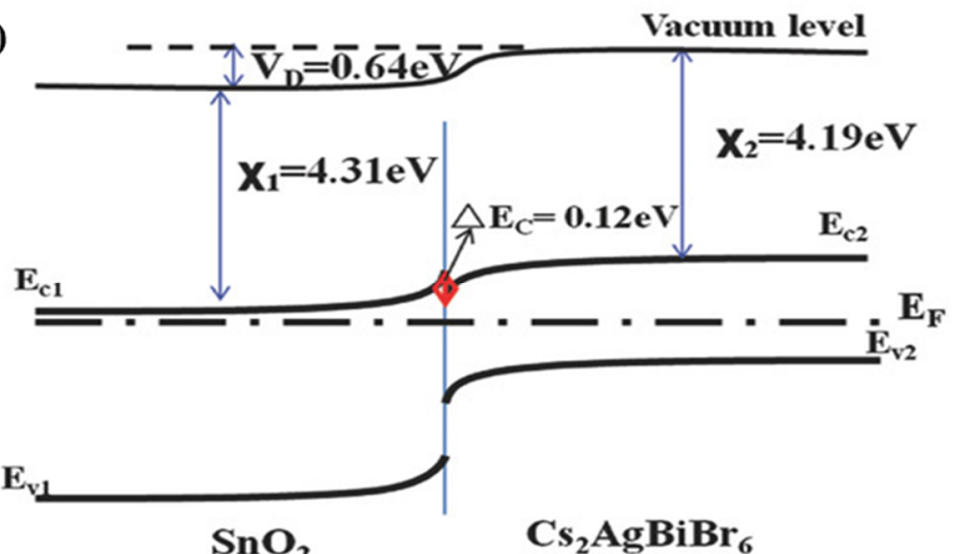

$\mathrm{Cs}_{2} \mathrm{AgBiBr}_{6}$

Figure 17. (a) Device configuration diagram and; (b) Band scheme diagram of $\mathrm{Cs}_{2} \mathrm{AgBiBr}_{6} / \mathrm{SnO}_{2}$ heterojunction. Reproduced with permission from [115]. Copyright 2018, Wiley-VCH.

Zhou et al. [116] reported the fabrication of $\mathrm{Cs}_{2} \mathrm{AgBiBr}_{6} \mathrm{NCs}$ by hot injection method for $\mathrm{CO}_{2}$ photocatalytic reduction. The prepared double halide perovskite demonstrated significant stability against moisture, light and temperature. It also showed a total electron consumption of $105 \mu \mathrm{mol} \mathrm{g}^{-1}$ under simulated solar light (AM 1.5G) for $6 \mathrm{~h}$. Zhang et al. [117] developed an alcohol-based photocatalytic system for dye degradation by applying $\mathrm{Cs}_{2} \mathrm{AgBiBr}_{6}$ double halide perovskite under visible light irradiation. During the photocatalytic process, $\mathrm{Cs}_{2} \mathrm{AgBiBr}_{6}$ kept its high chemical stability in ethanol, and due to the 
photocatalytic feature of $\mathrm{Cs}_{2} \mathrm{AgBiBr}_{6}$ surface, pseudo-zeroth-order kinetics was obtained, and the reaction rate was also comparable to well-known $\mathrm{CdS}$ photocatalyst semiconductor.

\section{2. $\mathrm{Cs} / \mathrm{In}^{3+-}$ Based Double Halide Perouskites}

\subsection{1. $\mathrm{Cs}_{2} \mathrm{M}^{+} \mathrm{In}^{3+} \mathrm{X}_{6}$ : Theoretical Results}

In 2017, Volonakis et al. [118] by using first-principle calculations, identified the direct bandgap of $\mathrm{Cs}_{2} \mathrm{AgInX}_{6}(\mathrm{X}=\mathrm{Cl}, \mathrm{Br})$ halide double perovskites. According to DFT/LDA calculation, In-based perovskites showed smaller lattice constant compared to Bi-Based analogous due to the smaller size of $\mathrm{In}^{3+}$. Preliminary assessment of octahedral and tolerance factor exhibited that because of smaller ionic radii of $\operatorname{In}^{3+}(0.8 \AA)$, the coordination between $\mathrm{In}^{3+}$ and $\mathrm{I}^{-}$ions would be impossible, and therefore, the synthesis of $\mathrm{Cs}_{2} \mathrm{AgInX} \mathrm{X}_{6}$ $(\mathrm{X}=\mathrm{Cl}, \mathrm{Br}$ and $\mathrm{Cl} / \mathrm{Br}$ ) double halide perovskite may be amenable. Nominal bandgap for the $\mathrm{Cs}_{2} \mathrm{AgInCl}_{6}$ based on theoretical calculation (HSE and PBE0 hybrid functionals) was reported to be of $2.07 \mathrm{eV}$ with a bias of $0.6 \mathrm{eV}$ (Figure 18a,b). They also demonstrated the VBM was mainly comprised of Cl-3p and In- $4 \mathrm{~d} / \mathrm{Ag}-4 \mathrm{~d}$ states while the CBM was occupied by Cl-3p and In-5s/Ag-5s states. The electron and hole effective masses were reported to be $0.20 \mathrm{~m}_{\mathrm{e}}$ and $0.28 \mathrm{~m}_{\mathrm{h}}$, respectively.

(a)
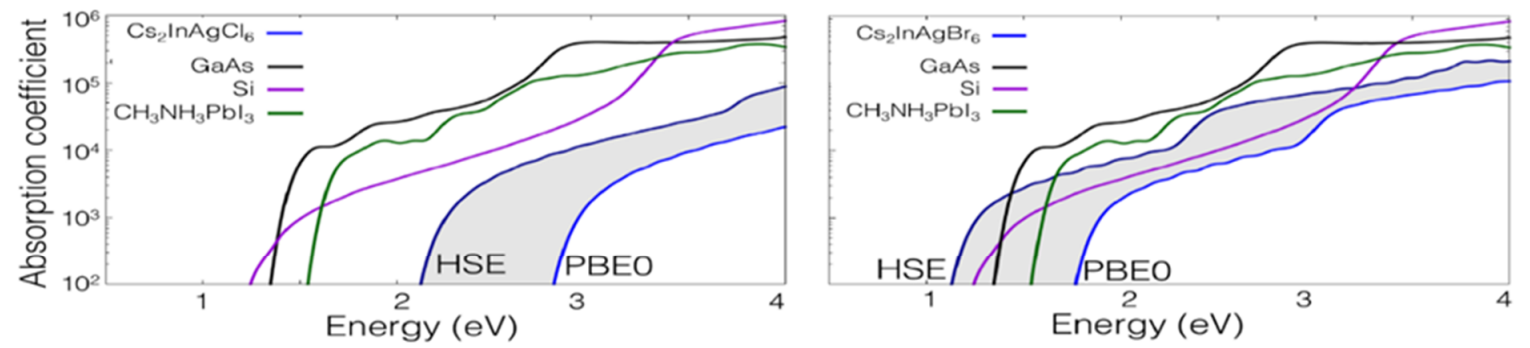

(b)
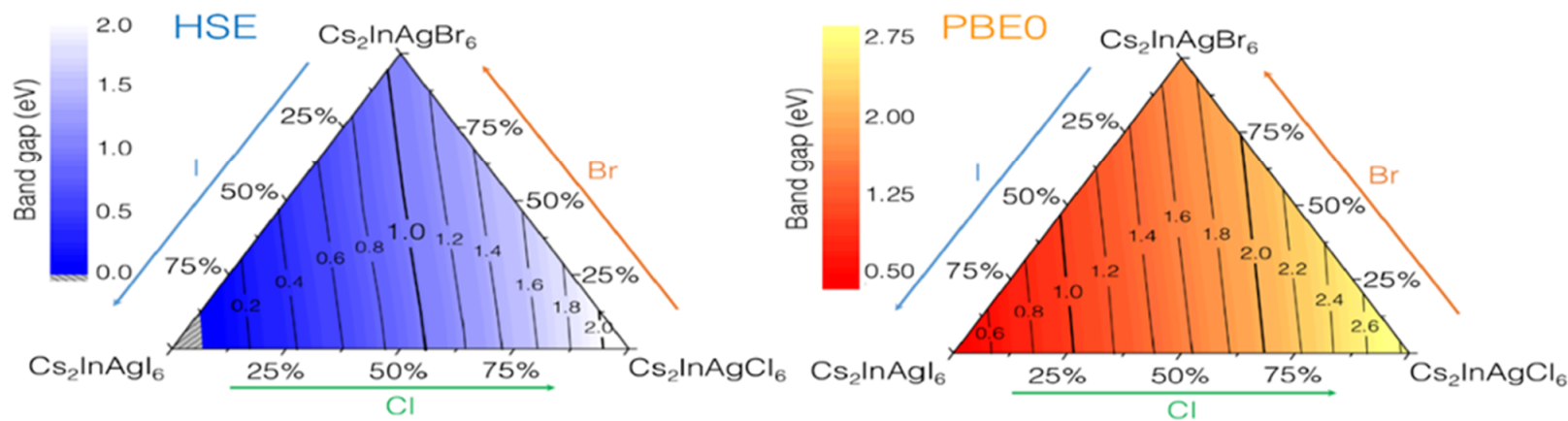

Figure 18. (a) Calculated absorption coefficient of the synthesized compound, $\mathrm{Cs}_{2} \mathrm{InAgCl}_{6}$, and hypothetical compound, $\mathrm{Cs}_{2} \mathrm{InAgBr}_{6}$, compared with the theoretical absorption coefficients of $\mathrm{Si}, \mathrm{GaAs}$ and $\mathrm{MAPbI}_{3}$; (b) Calculated band gaps of hypothetical mixed-halide double perovskites $\mathrm{Cs}_{2} \operatorname{InAg}\left(\mathrm{Cl}_{1-\mathrm{x}-\mathrm{y}} \mathrm{Br}_{\mathrm{x}} \mathrm{I}_{\mathrm{y}}\right)_{6}$ within the HSE (left) and PBE0 (right) hybrid functional. The corners of the triangle correspond to $\mathrm{Cs}_{2} \mathrm{InAgX}_{6}$ with $\mathrm{X}=\mathrm{Cl}, \mathrm{Br}$, I. Reproduced with permission from [118]. Copyright 2017, American Chemical Society.

Zhao et al. [119] as provided in Table 4, inspired by $\mathrm{Cu}[\mathrm{In}, \mathrm{Ga}] \mathrm{Se}_{2}$ (CIGS) chalcopyrite solar absorbers [120-122], designed 36 different candidates of double halide perovskites where $\mathrm{A}=\mathrm{Cs}, \mathrm{Rb}, \mathrm{K} ; \mathrm{M}^{+}=\mathrm{Cu}, \mathrm{Ag} ; \mathrm{M}^{3+}=\mathrm{Ga}$, In and $\mathrm{X}=\mathrm{Cl}$, Br, I through first-principles calculations. Although all the compounds showed direct bandgaps, three of them exhibited remarkable bandgap of $1.36 \mathrm{eV}\left(\mathrm{Rb}_{2} \mathrm{CuInCl}_{6}\right), 1.46 \mathrm{eV}\left(\mathrm{Rb}_{2} \mathrm{AgInBr}_{6}\right)$ and $1.50 \mathrm{eV}$ $\left(\mathrm{Cs}_{2} \mathrm{AgInBr}_{6}\right)$. Generally, Cu-based compounds showed smaller bandgap than Ag-based perovskites. The screening thermodynamic stability of compounds exhibited positive $\Delta \mathrm{H}_{\mathrm{dec}}$ that led to suppressed decomposition of compounds. Their study [119] showed that by increasing the film thickness up to $2 \mu \mathrm{m}$, spectroscopic limited maximum efficiency (SLME) increased to approximately $28 \%$. This value was attributed to small direct 
bandgaps of $\mathrm{Rb}_{2} \mathrm{CuInCl}_{6}, \mathrm{Rb}_{2} \mathrm{AgInBr}$ and $\mathrm{Cs}_{2} \mathrm{AgInBr}_{6}$ materials which were close to optimal bandgap of $1.34 \mathrm{eV}$ calculated for Shockley-Queisser limit. This SLME value (28\%) was comparable to the obtained SLME values for CuInSe 2 (31.5\%) and $\mathrm{CH}_{3} \mathrm{NH}_{3} \mathrm{PbI}_{3}(30 \%)$.

The intrinsic defects of In-based double halide perovskite were investigated by $\mathrm{Xu}$ et al. [123] through the first-principle calculation. The theoretical study of band structure showed hybridization of $\mathrm{Ag}(\mathrm{d})$ and ionic $X(\mathrm{p})$ orbitals along with negligible coupling with In (s) orbital resulted in direct bandgap where both VBM and CBM were placed at $\Gamma$ point of $\mathrm{Cs}_{2} \mathrm{AgInCl}_{6}$. It was expected that $\mathrm{Cs}_{2} \mathrm{AgInCl}_{6}$ shows more point defects as a quaternary compound, which makes the growth of high-quality film challenging. It was shown that in order to avoid of deep-level defects and unwanted secondary phases, the synthesis of film should be done in Ag-rich growth condition. It was also suggested that depending on chemical growth condition, the conductivity of $\mathrm{Cs}_{2} \mathrm{AgInCl}_{6}$ could change from good n-type/poor n-type to intrinsic semiconducting.

\subsection{2. $\mathrm{Cs}_{2} \mathrm{M}^{+} \mathrm{In}^{3+} \mathrm{X}_{6}$ : Experimental Results}

- $\quad \mathrm{Cs}_{2} \mathrm{M}^{+} \mathrm{In}^{3+} \mathrm{X}_{6}$ : Single-Crystals, Polycrystalline and Nanocrystals-Based Perovskites

In order to verify the accuracy of theoretical studies on stability, direct bandgap and balanced effective masses of $\mathrm{Cs}_{2} \mathrm{AgIn}_{6}(\mathrm{X}=\mathrm{Cl}, \mathrm{Br})$ Volonakis et al. [118] synthesized the materials through precipitation from the acid solution. The experimental measurements were in a good agreement with their theoretical results. The optical bandgap obtained by experimental measurements was $3.3 \mathrm{eV}$ as presented in Table 4.

Zhou et al. [124] synthesized $\mathrm{Cs}_{2} \mathrm{AgInCl}_{6}$ perovskite crystals by using hydrothermal method. The size of the crystals varied between 5 to $15 \mu \mathrm{m}$ which was due to the different reaction time. Rietveld analysis for XRD measurement of $\mathrm{Cs}_{2} \mathrm{AgInCl}_{6}$ powder identified the cubic unit cell with the space group of $F m-3 m\left[\mathrm{AgCl}_{6}\right]$ and $\left[\mathrm{InCl}_{3}\right]$ octahedra in 3D framework. Time-resolved emission spectra showed two different decay times of 16.3 and $100 \mu$ s which was attributed to surface/defect states and fundamental nonradiative recombination. The optical bandgap measured by UV-vis reflectance spectroscopy was $3.23 \mathrm{eV}$ while this value determined to be $3.33 \mathrm{eV}$ by using band structure and optical absorption calculations. However, the compound showed to maintain high light, moisture and heat stability.

\subsection{3. $\mathrm{Cs}_{2} \mathrm{M}^{+} \mathrm{In}^{3+} \mathrm{X}_{6}$ : Doping}

In 2018, Nag et al. [96] prepared bulk Mn-doped $\mathrm{Cs}_{2} \mathrm{AgInCl}_{6}$ perovskite employing the same method used by Volonakis et al. [118] in order to study the photoluminescence properties. The optical measurements of samples showed a weak intensity of undoped sample while by increasing of $\mathrm{Mn}^{2+}$ concentration as dopant, the intensity of emissions raised up significantly. This was due to the de-excitation of $\mathrm{Mn}^{2+} \mathrm{d}$-electrons from ${ }^{4} \mathrm{~T}_{1} \rightarrow$ ${ }^{6} \mathrm{~A}_{1}$ state. Locandi and co-workers [97] prepared $\mathrm{Cs}_{2} \mathrm{AgInCl}_{6}$ and $\mathrm{Mn}$-doped $\mathrm{Cs}_{2} \mathrm{AgInCl}_{6}$ $\mathrm{NCs}$, using colloidal hot-injection method. Synthesis resulted in highly pure NCs without any undesired secondary phases for both $\mathrm{Cs}_{2} \mathrm{AgInCl}_{6}$ and $\mathrm{Mn}$-doped $\mathrm{Cs}_{2} \mathrm{AgInCl}_{6}$ as well as high thermal stability up to $500^{\circ}$. The experimentally obtained optical bandgap was larger compared to previously reported works $\left(4.38 \mathrm{eV}\right.$ for $\mathrm{Cs}_{2} \mathrm{AgInCl}_{6} \mathrm{NCs}$ and $4.36 \mathrm{eV}$ for Mn-doped $\mathrm{Cs}_{2} \mathrm{AgInCl}_{6} \mathrm{NCs}$ ). However, the Mn-doped $\mathrm{Cs}_{2} \mathrm{AgInCl}_{6} \mathrm{NCs}$ exhibited bright PL emissions with a PLQY of $16 \pm 4 \%$ which is comparable to $\mathrm{Cs}_{2} \mathrm{AgInCl}_{6} \mathrm{NCs}$ value $(1.6 \pm 1 \%)$. This result shows that doping with $\mathrm{Mn}^{2+}$ would make the $\mathrm{In}^{3+}$-based double halide perovskites a good candidate for different applications such as LEDs.

Tran et al. [125] through a solid-state technique synthesized $\mathrm{Cs}_{2} \mathrm{AgInCl}_{6}$ while the $\mathrm{Cs}_{2} \mathrm{AgSb}_{\mathrm{x}} \mathrm{In}_{1-\mathrm{x}} \mathrm{Cl}_{6}(\mathrm{x}=0.5,0.4$ and 0.2$)$ solid solutions were prepared by combining the single crystals of hydrothermally synthesized of $\mathrm{Cs}_{2} \mathrm{AgInCl}_{6}$ and $\mathrm{Cs}_{2} \mathrm{AgSbCl}_{6}$, in a stoichiometric ratio. UV-Vis diffuse reflectance measurement along with Tauc plot demonstrated, by increasing the $\mathrm{Sb}$ composition in $\mathrm{Cs}_{2} \mathrm{AgSb}_{\mathrm{x}} \mathrm{In}_{1-\mathrm{x}} \mathrm{Cl}_{6}(\mathrm{x}=0.5,0.4$ and 0.2 and 0 ), the bandgap would shift from direct to indirect while the value decreased from $3.53 \mathrm{eV}$ to $2.54 \mathrm{eV}$ in $\mathrm{Cs}_{2} \mathrm{AgSbCl}_{6}$ (Figure 19a,b). 
Table 4. Summary of prepared double halide perovskite samples based on Cs $/ \mathrm{In}^{3+}$.

\begin{tabular}{|c|c|c|c|c|c|c|c|c|}
\hline Compounds & Morphology & $\begin{array}{l}\text { Synthetic } \\
\text { Method }\end{array}$ & $\begin{array}{l}\text { Optical } \\
\text { Transi- } \\
\text { tion }\end{array}$ & $\begin{array}{c}\text { Theoretical } \\
\text { Bandgap }\end{array}$ & $\begin{array}{l}\text { Experimental } \\
\text { Bandgap }\end{array}$ & $\begin{array}{l}\text { Characterization } \\
\text { Techniques }\end{array}$ & $\begin{array}{c}\text { Theoretical } \\
\text { Calcula- } \\
\text { tion }\end{array}$ & Reference \\
\hline $\mathrm{Cs}_{2} \mathrm{AgInBr}_{6}$ & - & - & Direct & $1.50 \mathrm{eV}$ & - & - & $\begin{array}{l}\mathrm{DFT} / \mathrm{DFT} / \\
\mathrm{PBE} / \mathrm{HSE}\end{array}$ & [119] \\
\hline $\mathrm{Cs}_{2} \mathrm{AgInCl}_{6}$ & Powder & $\begin{array}{l}\text { Solution- } \\
\text { based } \\
\text { process } \\
\text { using } \\
\text { hydrohalic } \\
\text { acid }\end{array}$ & Direct & $\begin{array}{c}2.1 \leq \mathrm{E}_{\mathrm{g}} \leq \\
3.3 \\
\text { (depends } \\
\text { on } \\
\text { calculation } \\
\text { method) }\end{array}$ & $3.3 \mathrm{eV}$ & $\begin{array}{c}\text { X-ray, UV-Vis } \\
\text { spectroscopy, } \\
\text { PL, TRPL, }\end{array}$ & $\begin{array}{c}\text { DFT/LDA/ } \\
\text { HSE/PBE0/ } \\
\text { HSE }\end{array}$ & [118] \\
\hline $\mathrm{Cs}_{2} \mathrm{AgInCl}_{6}$ & $\begin{array}{l}\text { Polycrystalline } \\
\text { and single } \\
\text { crystals }\end{array}$ & $\begin{array}{l}\text { solid-state } \\
\text { reaction } \\
\text { and hy- } \\
\text { drothermal } \\
\text { reaction }\end{array}$ & Direct & $\begin{array}{c}5.0 \mathrm{eV} \\
\text { (without } \\
\text { SOC) }\end{array}$ & $3.53 \mathrm{eV}$ & $\begin{array}{c}\text { UV-Vis } \\
\text { spectroscopy, } \\
\text { SC-XRD, } \\
\text { PXRD, }\end{array}$ & $\begin{array}{c}\text { DFT-LDA, } \\
\text { FP- } \\
\text { LAPW+LO, } \\
\text { SOC }\end{array}$ & [125] \\
\hline $\mathrm{Cs}_{2} \mathrm{AgInCl}_{6}$ & Nanocrystals & $\begin{array}{c}\text { Hot- } \\
\text { injection } \\
\text { method }\end{array}$ & Direct & - & $3.57 \mathrm{eV}$ & $\begin{array}{c}\text { STEM-EDS, } \\
\text { UV-Vis-NIR } \\
\text { spectroscopy, } \\
\text { PL, PLE, TEM, } \\
\text { XRD }\end{array}$ & $\begin{array}{l}\text { DFT-VASP, } \\
\text { PBE-GGA }\end{array}$ & [85] \\
\hline $\mathrm{Cs}_{2} \mathrm{AgInCl}_{6}$ & Powder & $\begin{array}{l}\text { Hydrothermal } \\
\text { method }\end{array}$ & Direct & $3.33 \mathrm{eV}$ & $3.23 \mathrm{eV}$ & $\begin{array}{l}\text { TRPL, UV-Vis, } \\
\text { XRD, SEM, } \\
\text { UV-Vis } \\
\text { spectroscopy, } \\
\text { PL, TGA }\end{array}$ & $\begin{array}{l}\mathrm{DFT} / \mathrm{PAW} / \\
\mathrm{PBE} / \mathrm{VASP}\end{array}$ & [124] \\
\hline $\mathrm{Rb}_{2} \mathrm{AgInBr}_{6}$ & - & - & Direct & $1.46 \mathrm{eV}$ & - & 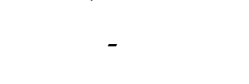 & $\begin{array}{l}\mathrm{DFT} / \mathrm{DFT} / \\
\mathrm{PBE} / \mathrm{HSE}\end{array}$ & [119] \\
\hline $\mathrm{Rb}_{2} \mathrm{CuInCl}_{6}$ & - & - & Direct & $1.36 \mathrm{eV}$ & - & - & $\begin{array}{l}\text { DFT/DFT/ } \\
\mathrm{PBE} / \mathrm{HSE}\end{array}$ & [119] \\
\hline
\end{tabular}

(a)

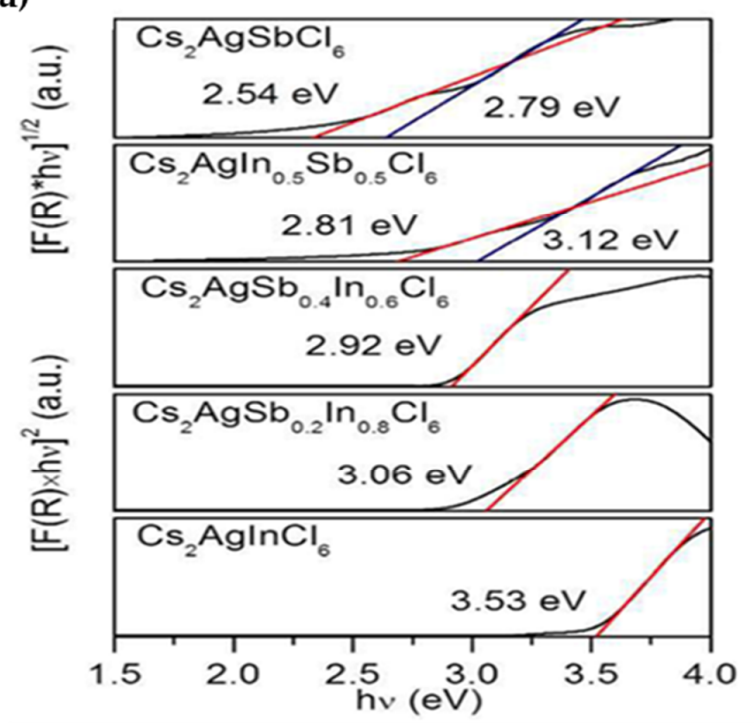

(b)

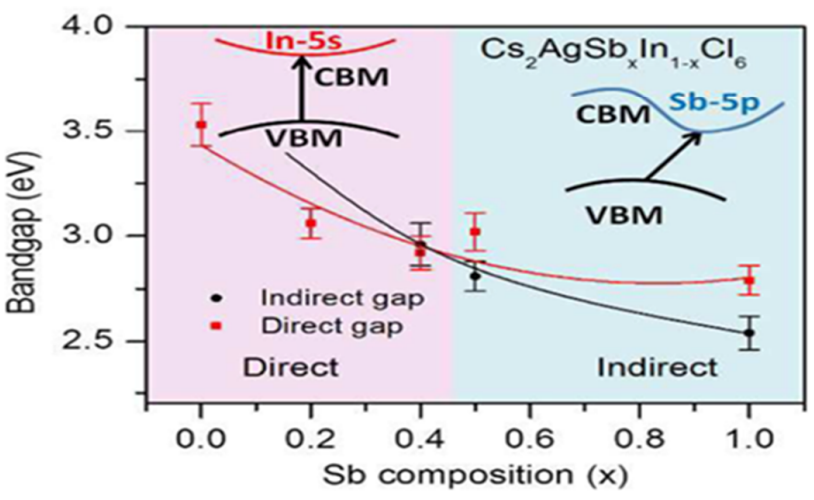

Figure 19. (a) Tauc plots for $\mathrm{Cs}_{2} \mathrm{AgSbCl}_{6}, \mathrm{Cs}_{2} \mathrm{AgSb}{ }_{0.5} \mathrm{In}_{0.5} \mathrm{Cl}_{6}, \mathrm{Cs}_{2} \mathrm{AgSb}_{0.4} \mathrm{In}_{0.6} \mathrm{Cl}_{6}, \mathrm{Cs}_{2} \mathrm{AgSb}_{0.2} \mathrm{In}_{0.8} \mathrm{Cl}_{6}$ and $\mathrm{Cs}_{2} \mathrm{AgInCl}_{6}$. The plots indicate the characteristics of an indirect bandgap for $\mathrm{Cs}_{2} \mathrm{AgSbCl}_{6}$, a direct bandgap for $\mathrm{Cs}_{2} \mathrm{AgInCl}_{6}$ and a transition from indirect to direct bandgap of $\mathrm{Cs}_{2} \mathrm{AgSb}_{\mathrm{x}} \mathrm{In}_{1-\mathrm{x}} \mathrm{Cl}_{6}$ at $\mathrm{x}=0.4$; (b) Phase diagram of $\mathrm{Cs}_{2} \mathrm{AgSb}_{\mathrm{x}} \mathrm{Ag}_{1-\mathrm{x}} \mathrm{Cl}_{6}$ showing the bandgap trend as a function of $\mathrm{Sb}$ composition and a crossover from indirect to direct optical absorption in a solid solution at $x=0.4$. Reproduced with permission from [125]. Copyright 2017, Royal Society of Chemistry. 
Liu et al. [99] by utilizing a facile hot injection method, prepared $\mathrm{Cs}_{2} \mathrm{AgInCl}_{6}$ and Bidoped $\mathrm{Cs}_{2} \mathrm{AgInCl}_{6} \mathrm{NCs}$. It was indicated that by controlling the reaction time both ligands and $\mathrm{HCl}$ concentration, the purer $\mathrm{NCs}$ without any impurity phases with desirable size and shapes would be produced. By increasing the reaction temperature from $180^{\circ}$ to $280^{\circ}$, the PLQY curve also rise and reached to highest PLQY of $11.4 \%$. TEM and HRTEM analysis of NCs formed at $180^{\circ}$ exhibited of some spherical particles which were ascribed to $\mathrm{Ag}_{2} \mathrm{O}$. Due to metal-ion-induced oxidation process the silver ions turn to silver nanoparticles. The size of undoped and doped (with $1 \% \mathrm{Bi}^{3+}$ ions) $\mathrm{NCs}$ were reported $9.79 \mathrm{~nm}$ and $10.59 \mathrm{~nm}$, respectively. The optical measurements of NCs revealed a broad orange peak at $580 \mathrm{~nm}$ for Bi-doped $\mathrm{Cs}_{2} \mathrm{AgInCl}_{6}$ and a blue emission peak at $470 \mathrm{~nm}$ for $\mathrm{Cs}_{2} \mathrm{AgInCl}_{6}$. It was also indicated that by doping $\mathrm{Bi}^{3+}$ in $\mathrm{Cs}_{2} \mathrm{AgInCl}_{6} \mathrm{NCs}$, the number of defects would decrease, and radiative localization would be promoted. The long-life time and broadened emission of Bi-doped $\mathrm{Cs}_{2} \mathrm{AgInCl}_{6} \mathrm{NCs}$ were attributed to self-trapped excitation (STEs) stemming from the Jahn-Teller distortion of $\left[\mathrm{AgCl}_{6}\right]$ octahedron in the excited state as well as the trivial sub-bandgap defect state transition.

In 2019, $\mathrm{Hu}$ et al. [98] prepared colloidal $\mathrm{Cs}_{2} \mathrm{Ag}_{1-\mathrm{x}} \mathrm{Na}_{\mathrm{x}} \mathrm{In}_{1-\mathrm{y}} \mathrm{Bi}_{\mathrm{y}} \mathrm{Cl}_{6} \quad(\mathrm{x}=0-1$; $\mathrm{y}=0.03-0.16) \mathrm{NCs}$ by a room temperature recrystallization process. The mean size of NCs were reported to be of $3 \mathrm{~nm}$ with diameter of $1.8-4.0 \mathrm{~nm}$ which could potentially confine the excitons. The remarkable blueshift photoluminescence was observed for the $\mathrm{NCs}$ which was comparable for bulk materials. Incorporation of partial amount of $\mathrm{Na}^{+}$ and $\mathrm{Bi}^{3+}$ resulted in bright near-white light emission with tunable color temperatures from 9759.7 to $4429.2 \mathrm{~K}$. Furthermore, the introduction of $\mathrm{Bi}^{3+}$ ions along with OA (ligand) passivation in $\mathrm{Cs}_{2} \mathrm{Ag}_{0.17} \mathrm{Na}_{0.83} \mathrm{In}_{0.88} \mathrm{Bi}_{0.12} \mathrm{Cl}_{6}$ nanocrystals led in PLQY of $64 \%$ which was the highest reported value for lead-free NCs to date.

In order to investigate the geometric, electric and photoluminescence properties of $\mathrm{Mn}^{2+}$-doped $\mathrm{Cs}_{2} \mathrm{AgInCl}_{6}$ double halide perovskite, Wu et al. [126] employed firstprinciple calculations. Their study showed that the presence of $\mathrm{Mn}$ as a dopant resulted in defect complexes by replacement of $\mathrm{Ag}^{+}$with $\mathrm{Mn}^{2+}$ atom and causing $\mathrm{Ag}$ vacancy $\left(\mathrm{Mn}_{\mathrm{Ag}}\right.$ $\mathrm{V}_{\mathrm{Ag}}$ ), which was due to the charge balance and weak distortion of the metal octahedra. Subsequently, this defect configuration introduced two defect bands in the forbidden gap which was associated to $3 \mathrm{~d}$ orbitals of the $\mathrm{Mn}^{2+}$ ions. Therefore, the transition of electron from the first excited state to the ground state led to lower PL spectrum compared to bandgap which would make it beneficial for LEDs.

In 2019, in order to tune the bandgap of $\mathrm{Cs}_{2} \mathrm{AgInCl}_{6}$, microcrystal and colloidal nanocrystals of $\mathrm{Yb}^{3+}$ doped $\mathrm{Cs}_{2} \mathrm{AgInCl}_{6}$ were prepared by Mahor et al. [100] through the solution-process and hot-injection methods, respectively. The concentration of $\mathrm{Yb}^{3+}$ content, analyzed by Inductively coupled plasma mass spectrometry (ICP-MS) was reported to have $0.1-1.6 \%$ for microcrystals and $6.2 \%$ for NCs. The Yb-doped samples showed an intense NIR emission centered at $\sim 994 \mathrm{~nm}$. Optical measurements of the samples indicated the light at first was absorbed by the light and then non-radiatively transferred to excite the $\mathrm{Yb}^{3+}$ ions and resulted in the de-excitation of (f) electrons in $\mathrm{Yb}^{3+}$ ions $\left({ }^{2} \mathrm{~F}_{5 / 2} \rightarrow{ }^{2} \mathrm{~F}_{7 / 2}\right)$. However, the PL decay was different for microcrystals compared to nanocrystals doped perovskites. The NCs exhibited a biexponential decay of $3 \mathrm{~ms}$ and $749 \mu \mathrm{s}$, and the microcrystals showed a single-exponential decay of $\mathrm{Yb}$-emission with a lifetime of $2.7 \mathrm{~ms}$. The samples also showed high stability under ambient environment.

In 2020 , the $\mathrm{Pb}$-free double halide perovskite $\mathrm{Cs}_{2} \mathrm{NaInCl}_{6}: \mathrm{Sb}^{3+}$ was prepared by Gray et al. [101] through precipitation from an $\mathrm{HCl}$ solution with the aim of photoluminescent properties investigation. The PXRD analysis of doped and undoped compounds indicated Fm-3m crystal symmetry, $a=10.553344(4) \AA$ with rock salt fully ordering of $\operatorname{In}^{3+}$ and $\mathrm{Na}^{3+}$ ions sites. The compound showed a large bandgap of $\sim 5.1 \mathrm{eV}$. However, the substitution of $\mathrm{In}^{3+}$ with $\mathrm{Sb}^{3+}$ resulted in strong absorption in the UV because of $5 \mathrm{~s}^{2} \rightarrow$ $5 s^{1} 5 p^{1}$ transitions of $\left[\mathrm{SbCl}_{6}\right]^{3-}$. Through the transition from ${ }^{3} \mathrm{P}_{1} \rightarrow{ }^{1} \mathrm{~S}_{0}$ with radiative relaxation back to $5 \mathrm{~s}^{2}$ ground state, strong blue luminescence at $445 \mathrm{~nm}$ with a PLQY of $79 \%$ was observed. Nevertheless, with increasing of $\mathrm{Sb}^{3+}$ content in $\mathrm{Cs}_{2} \mathrm{NaInCl}_{6}$, more 
than $3 \%$ the PL intensity decreased. Furthermore, $\mathrm{Cs}_{2} \mathrm{NaInCl}_{6}: \mathrm{Sb}^{3+}$ showed smaller Stocks shift (0.94 and $1.38 \mathrm{eV}$ ) compared to vacancy ordered double perovskite $\mathrm{Cs}_{2} \mathrm{SnCl}_{6}$, which was due to the change of coordination number from 6 in $\mathrm{Cs}_{2} \mathrm{NaInCl}_{6}$ to 5 in $\mathrm{Cs}_{2} \mathrm{SnCl}_{6}$.

In a similar study, Zeng et al. [102] showed that doping of $10 \% \mathrm{Sb}^{3+}$ in $\mathrm{Cs}_{2} \mathrm{NaInCl}_{6}$ perovskite would break the parity forbidden transition as well as modulating of density of state (DOS) population which led to an optimized blue PLQY of $78.9 \%$ assigned to be self-trapped excitons (STEs).

\subsection{4. $\mathrm{Cs}_{2} \mathrm{M}^{+} \mathrm{In}^{3+} \mathrm{X}_{6}$ : Applications}

- Non-Photovoltaic Applications

In 2017, Luo et al. [127] fabricated single crystals of $\mathrm{Cs}_{2} \mathrm{AgInCl}_{6}$ by thermodynamic synthesis method for UV photodetection. The prepared single crystals showed light yellow color on surface with colorless interior. This phenomenon was explained by different compositions of sample which means oxygen or oxygen containing functional groups change the surface compositions, consequently the optical properties of sample would change. Furthermore, the optical measurements of sample verified the existence of parity-forbidden transition in $\mathrm{Cs}_{2} \mathrm{AgInCl}_{6}$, which had been already demonstrated by Yan et al. [53] through theoretical calculation. It was suggested that the large difference between experimentally obtained optical bandgap $(3.2 \mathrm{eV})$ and photoluminescence emission energy $(2.1 \mathrm{eV})$ was caused by parity-forbidden transitions. However, the fabricated UV photodetection device exhibited ultralow trap-density of $8.6 \pm 1.9 \times 10^{8} \mathrm{~cm}^{-3}$ which was comparable with $\mathrm{Pb}$ based perovskites value $\left(1.80 \pm 1.07 \times 10^{9} \mathrm{~cm}^{-3}\right)$, as well as high ON-OFF ratio of around 500 , fast photo response of $1 \mathrm{~ms}$, low dark current of $10 \mathrm{pA}$ at $5 \mathrm{~V}$ bias and high detectivity of $10^{12}$ Jones.

Co-doped $\mathrm{Cs}_{2} \mathrm{AgInCl}_{6}: \mathrm{Bi}^{3+}-\mathrm{Ln}^{3+}\left(\mathrm{Ln}^{3+}=\mathrm{Er}^{3+}\right.$ and $\left.\mathrm{Yb}^{3+}\right)$ perovskite, with the aim of improving both absorption and emission spectra of the $\mathrm{Cs}_{2} \mathrm{AgInCl}_{6}$ were prepared by Arfin et al. [128]. Their study showed that co-doping of $\mathrm{Bi}^{3+}$ in $\mathrm{Cs}_{2} \mathrm{AgInCl}_{6}$ along with $\mathrm{Ln}^{3+}\left(\mathrm{Ln}^{3+}=\mathrm{Er}^{3+}\right.$ and $\left.\mathrm{Yb}^{3+}\right)$ resulted in new optical absorption channel in a lower energy $(372 \mathrm{~nm})$, which is appropriate for excitation in commercial UV LEDs. This excited

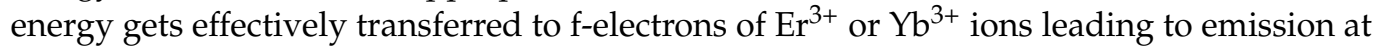
$1540 \mathrm{~nm}$ and $994 \mathrm{~nm}$, respectively and generally improve the near infrared (NIR) dopant emissions. Moreover, excitation at lower energy led to that co-doped $\mathrm{Bi}^{3+}-\mathrm{Er}^{3+}: \mathrm{Cs}_{2} \mathrm{AgInCl}_{6}$ exhibited 45-times higher emission intensity and co-doped $\mathrm{Bi}^{3+}-\mathrm{Yb}^{3+}: \mathrm{Cs}_{2} \mathrm{AgInCl}_{6}$ showed 27-times higher emission intensity compared to single doped $\mathrm{Er}^{3+}: \mathrm{Cs}_{2} \mathrm{AgInCl}_{6}$ and $\mathrm{Yb}^{3+}$ : $\mathrm{Cs}_{2} \mathrm{AgInCl}_{6}$ compounds.

\section{3. $\mathrm{Cs} / \mathrm{Sb}^{3+}$-Based Double Halide Perouskite}

\subsection{1. $\mathrm{Cs}_{2} \mathrm{M}^{+} \mathrm{Sb}^{3+} \mathrm{X}_{6}$ : Theoretical Results}

In 2017, Tran et al. [125], as presented in Table 5, exhibited a new design for engineering the convergence of direct and indirect bandgap in double halide perovskites based on chemical adjustment of (s) and (p) orbitals character in CBM. Because of differences in orbital overlaps, the relative crystals momenta of VBM and CBM determine whether a bandgap is direct or indirect. This means that bands derived by s-orbitals will increase in energy from $\Gamma$ to $X$ in a cubic Brillion zone while the bands derived by p-orbitals reduce in energy. Therefore, if the conduction band can be adjusted from $s$ orbitals to $p$ orbitals with a negligible change in the valance band consequently, the difference would result in shift from direct to indirect bandgap. By means of this theory, they examined the feasibility of their design strategy with the experimental preparation of $\mathrm{Cs}_{2} \mathrm{AgInCl}_{6}, \mathrm{Cs}_{2} \mathrm{AgSbCl}_{6}$ and $\mathrm{Cs}_{2} \mathrm{Sb}_{\mathrm{x}} \mathrm{In}_{1-\mathrm{x}} \mathrm{Cl}_{6}$ ( $\mathrm{x}=0.5,0.4$ and 0.2 ). Their experimental study successfully demonstrated that $\mathrm{Cs}_{2} \mathrm{AgInCl}_{6}$ and $\mathrm{Cs}_{2} \mathrm{AgSbCl}_{6}$ showed direct and indirect bandgaps, respectively. By employing the optimized amount of $60 \%: 40 \%$ for $\mathrm{In}^{3+}: \mathrm{Sb}^{3+}$ in $\mathrm{Cs}_{2} \mathrm{Sb}_{\mathrm{x}} \mathrm{In}_{1-\mathrm{x}} \mathrm{Cl}_{6}$, it was shown that the bandgap changes from indirect to direct. 
Table 5. Summary of prepared double halide perovskite samples based on $\mathrm{Cs} / \mathrm{Sb}^{3+}$.

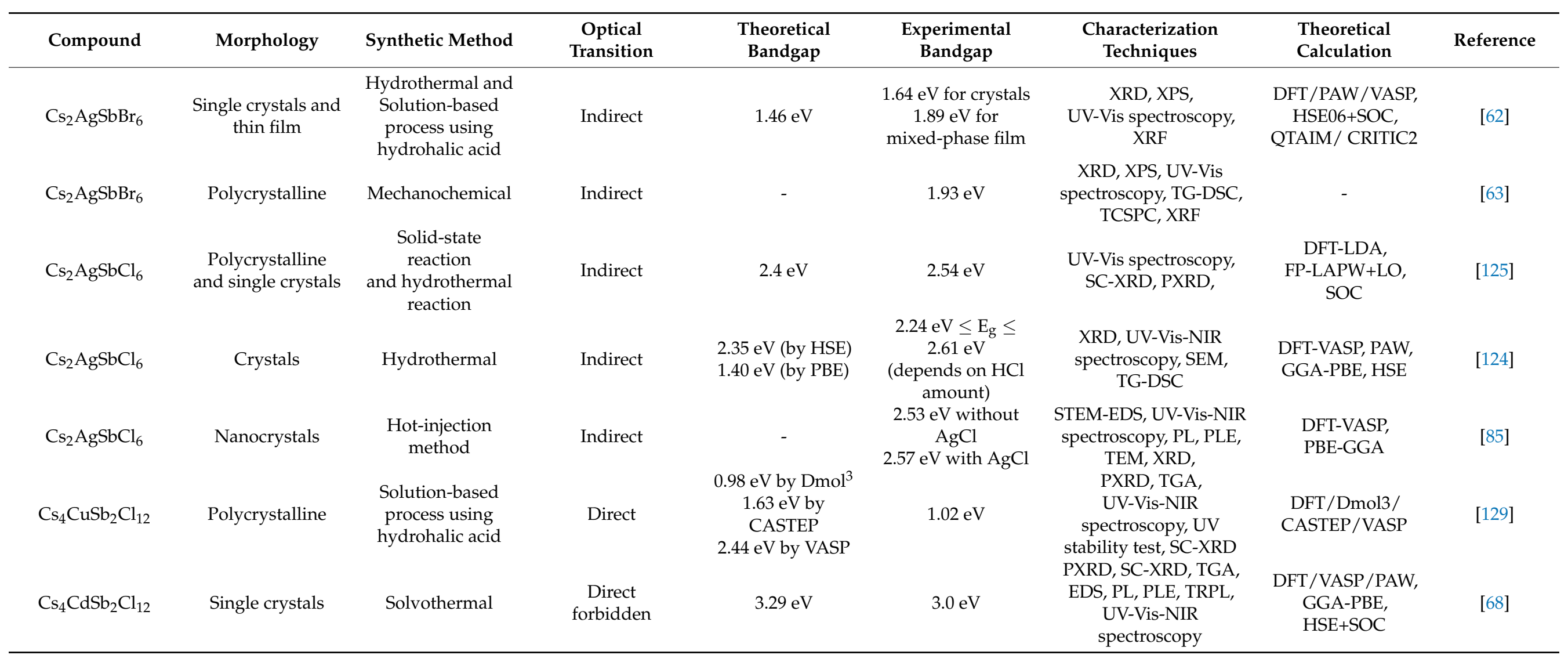


Zhou et al. [130] investigated the color-tuning phenomenon of $\mathrm{Cs}_{2} \mathrm{AgSbCl}_{6}$ crystals which occurred during the synthesis procedure by PBE approaches through first-principle calculation while anti-site defect was established as a model. It was shown that with exchanging site-equal $\mathrm{Ag}$ and $\mathrm{Sb}$ ions, the two allotropes of nearest neighbor (NN) and second nearest neighbor $(2 \mathrm{NN})$ were stable with only $7-12 \mathrm{meV}$ per atom larger than balanced structure $\left(E_{\text {balanced }}>E_{N N}>E_{2 N N}\right)$, and the relatively small lattice expansion resulted in different bandgaps.

In 2019, Wei et al. [62] investigated the crystallinity and symmetry of $\mathrm{Cs}_{2} \mathrm{AgSbBr}_{6}$ double halide perovskites by employing DFT calculations. It was shown that even though there was a similarity between band structure of $\mathrm{Cs}_{2} \mathrm{AgSbBr}_{6}$ and $\mathrm{Cs}_{2} \mathrm{AgBiBr}_{6}$, the $5 \mathrm{~s} 5 \mathrm{p}$ orbitals in $\mathrm{Sb}$ lowered the CBM significantly, which led to smaller bandgap in $\mathrm{Cs}_{2} \mathrm{AgSbBr}_{6}$ compared to $\mathrm{Cs}_{2} \mathrm{AgBiBr}_{6}$. Lin et al. [68] presented a strategy for developing quadruple perovskite halides. Through DFT calculations and symmetry analysis, $\mathrm{Cs}_{4} \mathrm{CdSb}_{2} \mathrm{Cl}_{12}$ and $\mathrm{Cs}_{4} \mathrm{CdBi}_{2} \mathrm{Cl}_{12}$ were identified as two stable perovskites with vacancy ordered $3 \mathrm{D}$ crystal structure along with $3 \mathrm{D}$ electronic dimensionality with direct forbidden bandgaps.

\subsection{2. $\mathrm{Cs}_{2} \mathrm{M}^{+} \mathrm{Sb}^{3+} \mathrm{X}_{6}$ : Experimental Results}

- $\mathrm{Cs}_{2} \mathrm{M}^{+} \mathrm{Sb}^{3+} \mathrm{X}_{6}$ : Single-Crystals, Polycrystalline and Nanocrystals-Based Perovskites

Zhou et al. [130] hydrothermally synthesized $\mathrm{Cs}_{2} \mathrm{AgSbCl}_{6}$ crystals and demonstrated by increasing the amount of $\mathrm{HCl}$ as a solvent from 0.5 to $1.5 \mathrm{~mL}$, the color of prepared powders changed from yellow to near black, which directly influenced on bandgap. While the darker samples showed lower bandgaps and the lighter color samples indicated higher bandgap as depicted in Figure 20a-c.

(a)

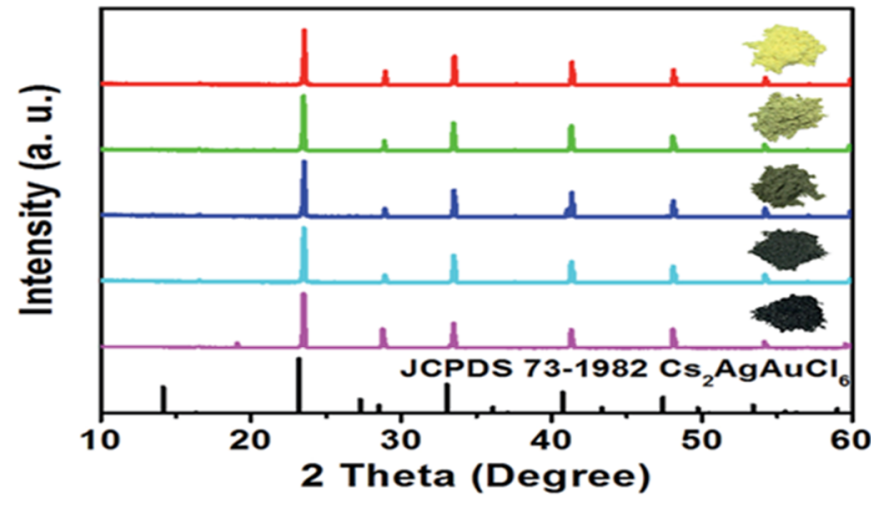

(b)

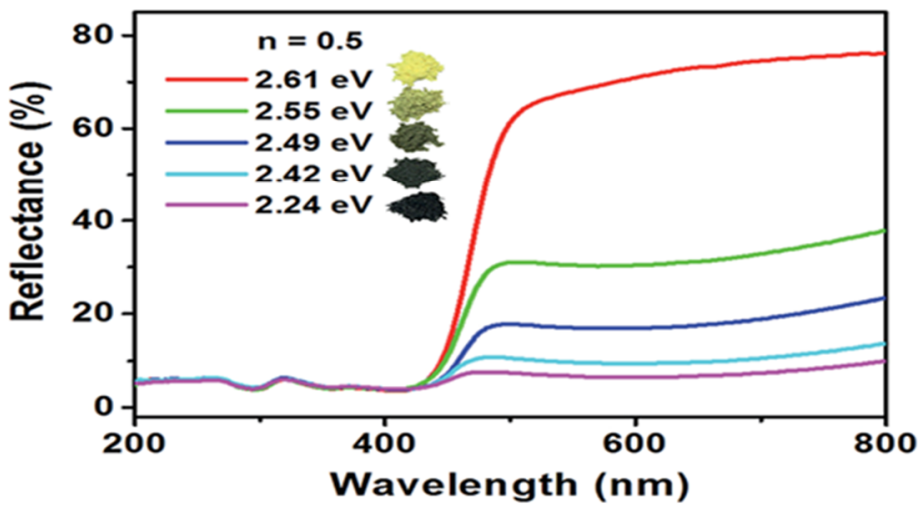

(c)

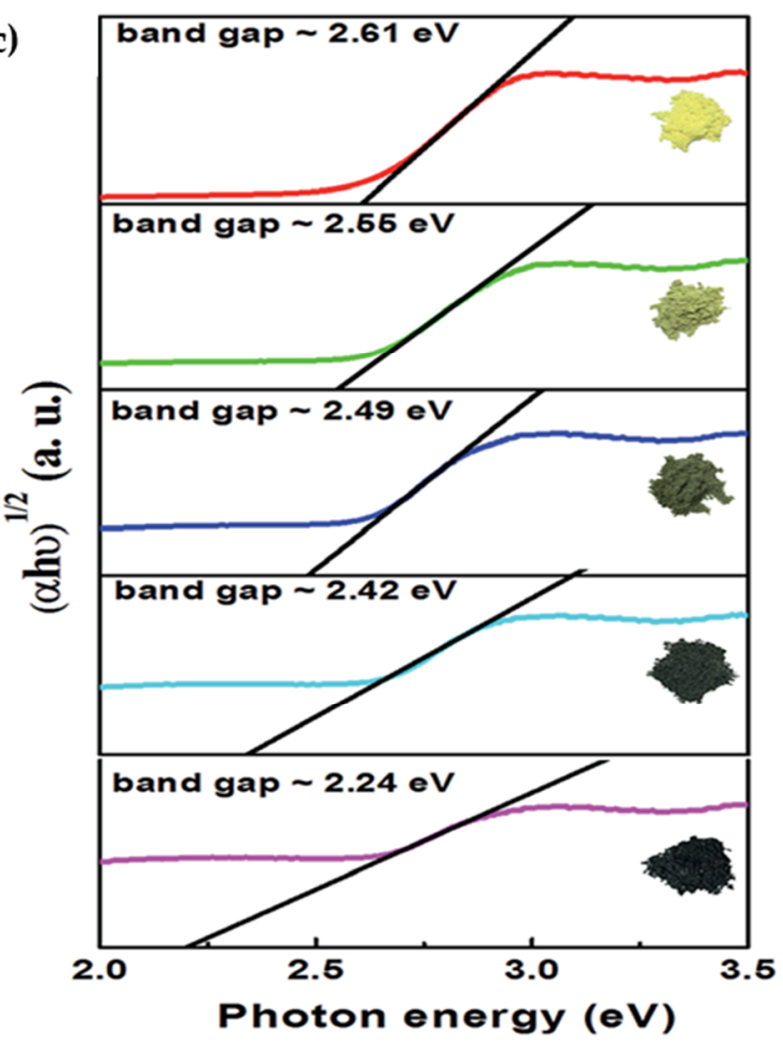

Figure 20. (a) XRD pattern; (b) UV-vis diffuse spectra and; (c) Tauc plots of as-synthesized $\mathrm{Cs}_{2} \mathrm{AgSbCl}_{6}$ samples obtained by employing of different amounts of $\mathrm{HCl}(0.5,0.75,1.0,1.25$ and $1.5 \mathrm{~mL})$ with variable visible light absorbance. Reproduced with permission from [130]. Copyright 2018, Royal Society of Chemistry. 
Vargas et al. [129] by incorporation of $\mathrm{Cu}^{2+}$ and $\mathrm{Sb}^{3+}$ through a solution method, prepared a 2D layered double halide perovskite, $\mathrm{Cs}_{4} \mathrm{Sb}_{2} \mathrm{CuCl}_{12}$, which exhibited a promising direct bandgap of around $\sim 1 \mathrm{eV}$, due to the unpaired electron in the $3 \mathrm{~d}$ orbital of $\mathrm{Cu}^{2+}$. The crystalline structure of the perovskite comprised of $[\mathrm{CuCl6}]^{4-}$ octahedra which was placed between $[\mathrm{SbCl6}]^{3-}$ layers and corner-shared to $[\mathrm{SbCl6}]^{3-}$ octahedra. The prepared perovskite showed high stability against moisture, light and temperature.

In 2019, Wei et al. [62] prepared a bulk form of $\mathrm{Cs}_{2} \mathrm{AgSbBr}_{6}$ double halide perovskite through the hydrothermal method. The prepared samples showed a low indirect bandgap of $1.64 \mathrm{eV}$ for single crystals. The color of as-prepared samples changed from black to brown by increasing the temperature to $480 \mathrm{~K}$ for $5 \mathrm{~min}$, which could be ascribed to charge transfer between $\mathrm{Sb}^{3+}$ and $\mathrm{Sb}^{5+}$ in a black phase.

Dahl et al. [85] synthesized $\mathrm{Cs}_{2} \mathrm{AgSbCl}_{6}$ and $\mathrm{Cs}_{2} \mathrm{AgInCl}_{6}$ nanocrystals by using a modified hot injection method. Instead of adding cesium oleate which is regularly used in the synthesis of double halide perovskites acyl halides was added into the solution of metal acetate precursors under ambient environment at mild temperatures. It was found that the concentration and type of acyl halide had a deep effect on synthesized nanocrystals. The prepared crystalline nano-cubes showed an edge length of $10 \mathrm{~nm}$ terminated with (200) facets as well as small silver nano-crystallites decorating the cubes. By developing a titration essay, in order to test the stability of prepared NCs, Dahl et al. [85] observed that $\mathrm{Cs}_{2} \mathrm{AgSbCl}_{6}$ dissolved in the presence of minimum concentration $(0.01-0.1 \mathrm{mM})$ of octylamine and released more than twice decomposition energy compared to $\mathrm{Cs}_{2} \mathrm{AgInCl}_{6}$ and $\mathrm{CsPbCl}_{3}$ as illustrated in Figure 21a,b.

(b)

(a)

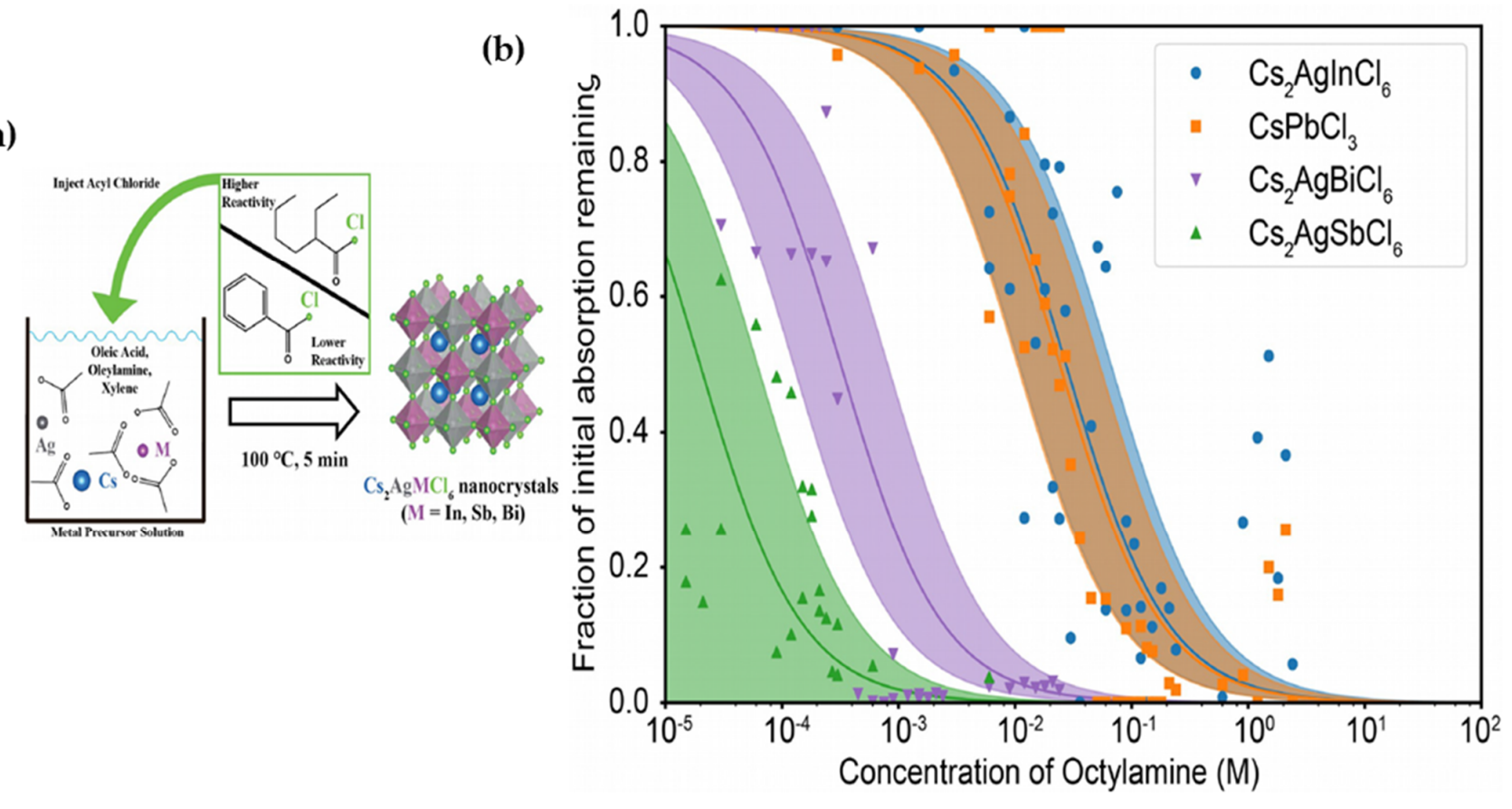

Figure 21. (a) reaction sketch for the preparation of double halide $\mathrm{Cs}_{2} \mathrm{AgSbCl}_{6}, \mathrm{Cs}_{2} \mathrm{AgInCl}_{6}$ and $\mathrm{Cs}_{2} \mathrm{AgBiCl}_{6}$ perovskite NCs. A solution of metal acetates (cesium, silver and indium, antimony or bismuth) in xylene with oleic acid and oleylamine is heated to $100{ }^{\circ} \mathrm{C}$, then an acyl chloride precursor is injected to form $\mathrm{NCs}$ of the corresponding $\mathrm{Cs}_{2} \mathrm{AgMCl}_{6}(\mathrm{M}=\mathrm{In}, \mathrm{Sb}, \mathrm{Bi})$ double perovskite. The reactivity of the acyl chloride precursor is an important factor for tuning nanocrystal formation; (b) analysis of stability for $\mathrm{Cs}_{2} \mathrm{AgSbCl}_{6}, \mathrm{Cs}_{2} \mathrm{AgInCl}_{6}$ and $\mathrm{Cs}_{2} \mathrm{AgBiCl}_{6}$ and $\mathrm{CsPbCl}_{3} \mathrm{NCs}$. Individual points represent the fraction of initial absorption remaining after $4 \mathrm{~h}$ as a function of the different concentrations of octylamine that the nanocrystal solutions were exposed to. Reproduced with permission from [85]. Copyright 2019, American Chemical Society.

Lin et al. [68] synthesized $\mathrm{Cs}_{4} \mathrm{CdSb}_{2} \mathrm{Cl}_{12}$ and $\mathrm{Cs}_{4} \mathrm{CdBi}_{2} \mathrm{Cl}_{12} 3 \mathrm{D}$ perovskites by solvothermal method in order to support their theoretical results. The steady-state PL exhibited 
warm orange emission, while the transient PL showed carrier recombination lifetime of microseconds at low temperature.

Garcia-Espejo et al. [63] by employing a mechanochemical approach, prepared polycrystalline inorganic $\mathrm{Cs}_{2} \mathrm{AgSbBr}_{6}$ double perovskites. Bromide derivative salts were added to a high energy ball mill with different molar ratio under atmospheric condition. Due to the thermodynamic instability of $\mathrm{Cs}_{2} \mathrm{AgSbBr}_{6}, \mathrm{XRD}$ for $\mathrm{Cs}_{2} \mathrm{AgSbBr}_{6}$ showed varied $\mathrm{X}$-ray diffraction peaks showing the formation of side phases such as $\mathrm{AgBr}, \mathrm{CsAgBr}_{2}$ and $\mathrm{Cs}_{3} \mathrm{Sb}_{2} \mathrm{Br}_{9}$. It was demonstrated that $2 \mathrm{D}$ layered of $\mathrm{Cs}_{3} \mathrm{Sb}_{2} \mathrm{Br}_{9}$ is more stable than $3 \mathrm{D} \mathrm{Cs}{ }_{2} \mathrm{AgSbBr}_{6}$ double perovskite [131]. The $\mathrm{Cs}_{2} \mathrm{AgSbBr}_{6}$ bandgap from Tauc plot was estimated to be $1.93 \mathrm{eV}$.

Deng et al. [132] integrated $\mathrm{Cs}_{2} \mathrm{AgSbCl}_{6}$ powder and $\mathrm{Cs}_{2} \mathrm{AgSbCl}_{6} / \mathrm{TiO}_{2}$ heterojunction nanoparticles through solution state method and hydrothermal process, respectively. Optical bandgaps of $2.60 \mathrm{eV}$ from optical absorption curve for $\mathrm{Cs}_{2} \mathrm{AgSbCl}_{6}$ were obtained. However, the optical absorption was seen improved for $\mathrm{Cs}_{2} \mathrm{AgSbCl}_{6} / \mathrm{TiO}_{2}$ heterojunction sample in the visible region as a result of interface states formation and lowered bandgap showing the facilitation of the photo-induced optical transitions. The comparison of charge transfers of $\mathrm{Ag}_{2} \mathrm{Sb}_{2} \mathrm{Cl}_{8} / \mathrm{TiO}_{2}$ and $\mathrm{Cs}_{4} \mathrm{Cl}_{4} / \mathrm{TiO}_{2}$ indicated that photo-induced carrier separation was more efficient at $\mathrm{Cs}_{4} \mathrm{Cl}_{4} / \mathrm{TiO}_{2}$ interface.

\subsection{3. $\mathrm{Cs}_{2} \mathrm{M}^{+} \mathrm{Sb}^{3+} \mathrm{X}_{6}$ : Doping}

Tran et al. [125] through the solid-state technique synthesized $\mathrm{Cs}_{2} \mathrm{AgSbCl}_{6}$ perovskite and $\mathrm{Cs}_{2} \mathrm{AgSb}_{\mathrm{x}} \mathrm{In}_{1-\mathrm{x}} \mathrm{Cl}_{6}(\mathrm{x}=0.5,0.4$ and 0.2$)$ were prepared by combining the single crystals of hydrothermally synthesized $\mathrm{Cs}_{2} \mathrm{AgInCl}_{6}$ and $\mathrm{Cs}_{2} \mathrm{AgSbCl}_{6}$ in a stoichiometric ratio. UV-Vis diffuse reflectance measurement along with Tauc plot demonstrated that by increasing the $\mathrm{Sb}$ composition in $\mathrm{Cs}_{2} \mathrm{AgSb}_{\mathrm{x}} \mathrm{In}_{1-\mathrm{x}} \mathrm{Cl}_{6}(\mathrm{x}=0.5,0.4$ and 0.2 and 0$)$, the bandgap would shift from direct to indirect while the value decreased from $3.53 \mathrm{eV}$ to $2.54 \mathrm{eV}$ in $\mathrm{Cs}_{2} \mathrm{AgSbCl}_{6}$.

Karmakar et al. [103] by investigating of $\mathrm{Cs}_{2} \mathrm{AgSbCl}_{6}$ and $\mathrm{Cu}^{2+}$-doped $\mathrm{Cs}_{2} \mathrm{AgSbCl}_{6}$ double halide perovskites reported of a well- ordered crystal structure with integration of $\mathrm{Cu}^{2+}$ ions into the lattice where $\mathrm{Ag}^{+}$ions were replaced by $\mathrm{Cu}^{2+}$. The results of optical measurements showed that $\mathrm{Cu}^{2+}$ ions had a direct effect on reduction of bandgap from $2.56 \mathrm{eV}\left(\mathrm{Cs}_{2} \mathrm{AgSbCl}_{6}\right)$ to $1.02 \mathrm{eV}$ for $\mathrm{Cu}$-doped $\mathrm{Cs}_{2} \mathrm{AgSbCl}_{6}\left(\mathrm{x}=0.1 \mathrm{Cu}^{2+}\right)$. The prepared $\mathrm{Cu}$-doped $\mathrm{Cs}_{2} \mathrm{AgSbCl}_{6}$ perovskite exhibited significant stability up to 365 days. The DFT calculation demonstrated small carrier effective masses $\left(>0.4 \mathrm{~m}_{\mathrm{e}}\right)$. Furthermore, it was found that using $\mathrm{Cu}^{2+}$ ion as dopant increased the conductivity of semiconductor. Kshirsagar et al. [104] prepared $\mathrm{Cs}_{2} \mathrm{AgSb}_{1-\mathrm{x}} \mathrm{Bi}_{\mathrm{x}} \mathrm{Cl}_{6}$ alloy NCs with $0 \leq \mathrm{x} \leq 1$ by employing the hot-injection method. Incorporation of $\mathrm{Bi}^{3}$ in $\mathrm{Cs}_{2} \mathrm{AgSb}_{1-\mathrm{x}} \mathrm{Bi}_{\mathrm{x}} \mathrm{Cl}_{6} \mathrm{NCs}(\mathrm{x}=0.36)$ raised the PL emission intensity to the maximum level of $2.74 \mathrm{eV}$. Also, a broadened red-shift emission was observed at $2.17 \mathrm{eV}$ which was ascribed to the carrier-phonon coupling leading intrinsic self-traps. The average length of $10 \mathrm{~nm}$ was characterized by TEM images, which proved that even with incorporation of $\mathrm{Bi}$, the size and shape of NCs remained unchanged. The absorption spectra of $\mathrm{Cs}_{2} \mathrm{AgSbCl}_{6}$ exhibited an absorption peak at 3.45 and $4.08 \mathrm{eV}$. Since the edge length of synthesized NCs were larger than Bohr radius $(1.02 \mathrm{~nm})$, and due to the absence of quantum confinement effect in NCs, no modifications in absorption spectrum were observed. However, the addition of $\mathrm{Bi}$ in $\mathrm{Cs}_{2} \mathrm{AgSb}_{1-x} \mathrm{Bi}_{x} \mathrm{Cl}_{6}(\mathrm{x}=1)$, decreased the bandgap from $3.45 \mathrm{eV}$ to $3.39 \mathrm{eV}$ as a result of larger spin-orbit coupling strength of $\mathrm{Bi}$ as well as anti-site disorders as shown in Figure 22a,b. 

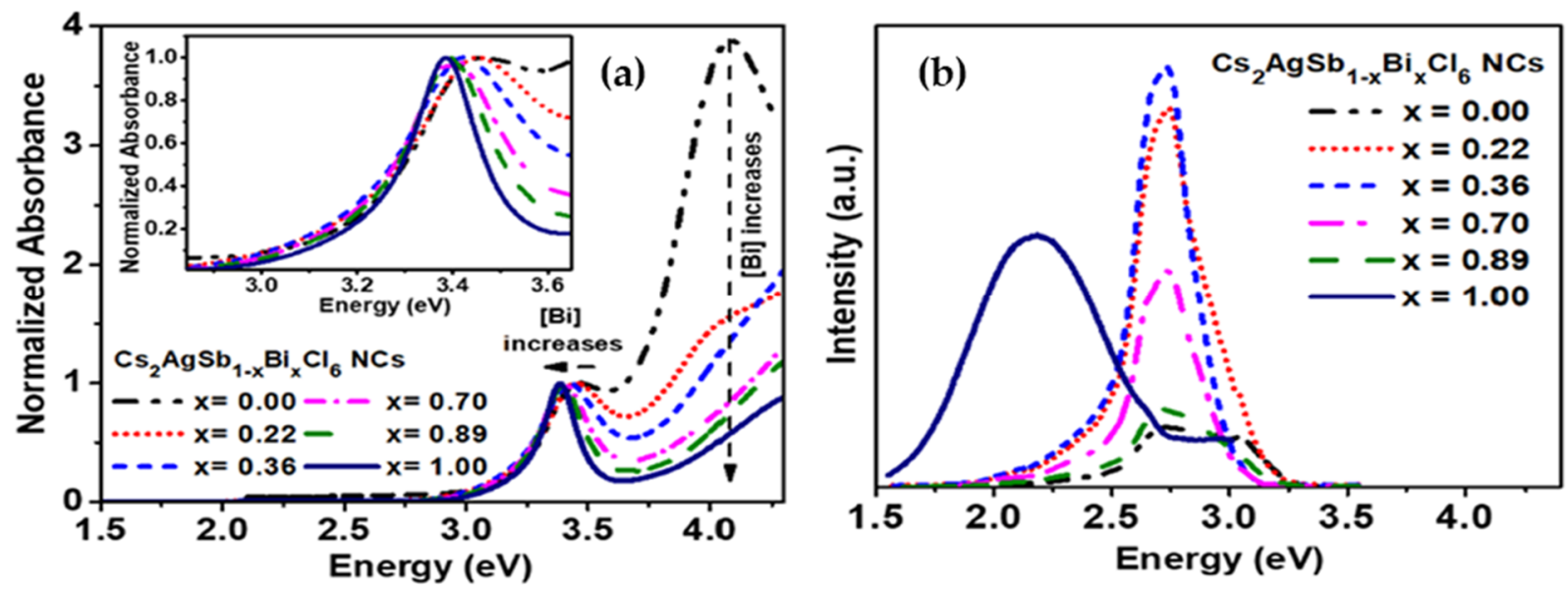

Figure 22. (a) UV-vis absorption and; (b) PL spectra after excitation at $310 \mathrm{~nm}$ for colloidal $\mathrm{Cs}_{2} \mathrm{AgSb}_{1-\mathrm{x}} \mathrm{BixCl}_{6}$ alloy $\mathrm{NCs}_{\text {. }}$ The samples in (a) all were normalized at $3.4 \mathrm{eV}$ which is the lowest energy peak. Reproduced with permission from [104]. Copyright 2019, American Institute of Physics.

\subsection{4. $\mathrm{Cs}_{2} \mathrm{M}^{+} \mathrm{Sb}^{3+} \mathrm{X}_{6}$ : Applications}

- Photovoltaic Applications

To the best of our knowledge, there have not been any significant studies on $\mathrm{Sb}^{3+}$ based double perovskite for PV application. The only fabricated PSC based on $\mathrm{Cs}_{2} \mathrm{AgSbBr}_{6}$ thin film was reported by Wei et al. [62] in 2019 with a very low photovoltaic efficiency $(0.01 \%)$, which was attributed to the presence of secondary phases with large bandgaps.

\subsection{Cs-Based Vacancy-Ordered Double Halide Perouskites}

Vacancy-ordered double perovskites are another form of double perovskite in which one $\mathrm{B}$-site cation is replaced by a vacancy and the other $\mathrm{B}$-site cation is in a oxidation state of $\mathrm{B}^{4+}\left(\mathrm{A}_{2} \mathrm{M}^{1+} \mathrm{M}^{3+} \mathrm{X}_{6} \rightarrow \mathrm{A}_{2} \square \mathrm{M}^{4+} \mathrm{X}_{6} \rightarrow \mathrm{A}_{2} \mathrm{M}^{4+} \mathrm{X}_{6}\right.$; where $\square$ indicates a vacancy). This category of perovskite materials also has the close-packed anionic lattice like $\mathrm{ABX}_{3}$. While in $\mathrm{ABX}_{3}$ structure, the stability of the perovskite is predicted by Goldschmidt tolerance factor, in $\mathrm{A}_{2} \mathrm{BX}_{6}$ structures the radius ratio is calculated by A-site cation radius to the 12-coordinate void [133-136] as shown in Figure 23a,b.

(a)

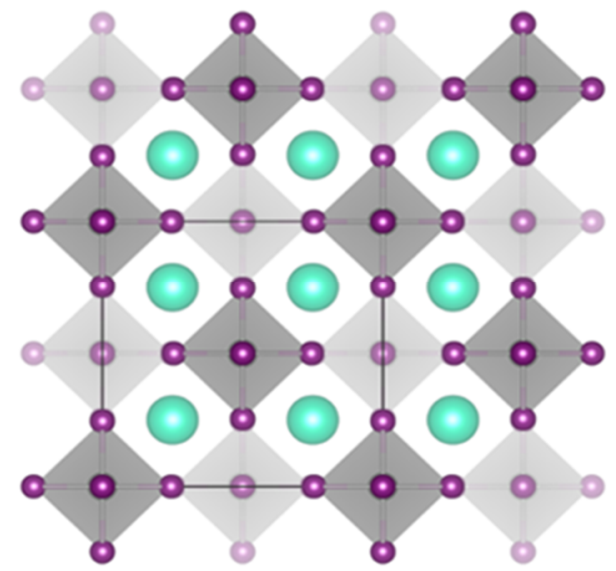

(b)

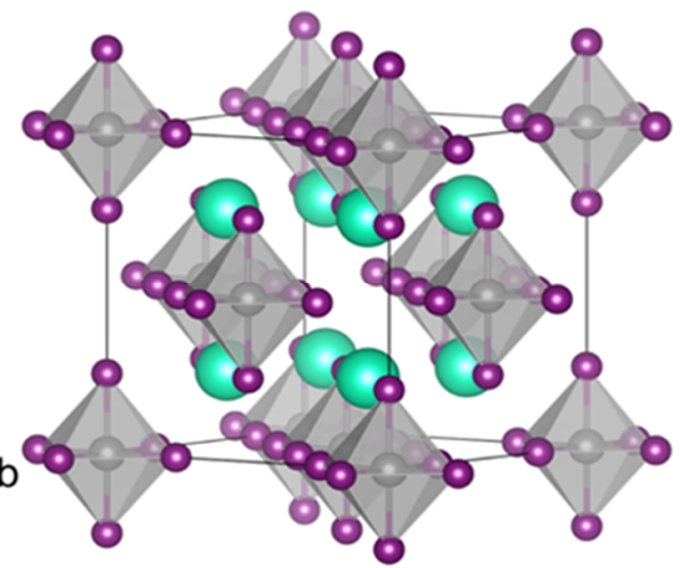

Figure 23. (a) Crystal structure of the vacancy-ordered double $\mathrm{Cs}_{2} \mathrm{SnI}_{6}$ and $\mathrm{Cs}_{2} \mathrm{TeI}_{6}$ perovskites; (b) Reorientation of the unit cell reveals the isolated octahedral units. Reproduced with permission from [136]. Copyright 2016, American Chemical Society. 


\subsection{1. $\mathrm{Cs}_{2} \mathrm{M}^{4+} \mathrm{X}_{6}$ : Theoretical Results}

In 2014, Lee et al. [137], as provided in Table 6, investigated the band structure of perovskite by DFT calculations and it was shown that $\mathrm{Cs}_{2} \mathrm{SnI}_{6}$ possessed a direct bandgap of $1.3 \mathrm{eV}$ at the $\Gamma$ point comprised of filled I-5p and empty I-6p/Sn-5p orbitals which contributed to VBM and CBM, respectively. Both VBM and CBM were dispersed in energy resulting in high charge carrier mobility of $\mathrm{Cs}_{2} \mathrm{SnI}_{6}$.

Maughan et al. [106] through DFT calculations indicated that the phonon interaction was stronger in $\mathrm{Rb}_{2} \mathrm{SnI}_{6}$ compared to $\mathrm{Cs}_{2} \mathrm{SnI}_{6}$. This was caused by the larger number of nondegenerate lower frequency phonons which contributed to the lattice dielectric response and decreased charge carrier mobilities. Debbichi et al. [138] theoretically studied the atomic and electronic band structures of single crystal and polycrystal $\mathrm{Cs}_{2} \mathrm{Au}_{2} \mathrm{I}_{6}$. It was shown that $\mathrm{Au}$ demonstrated mixed-valence of +1 and +3 in the B-site, which made the $\mathrm{Cs}_{2} \mathrm{Au}_{2} \mathrm{I}_{6}$ to exhibit the same electronic structure as double perovskite materials resulting in an optimal bandgap of $1.31 \mathrm{eV}$. An in-depth optical simulation done by Debbichi et al. [138] suggested that polycrystalline $\mathrm{Cs}_{2} \mathrm{Au}_{2} \mathrm{I}_{6}$ would be a good candidate for $\mathrm{PV}$ application because of its remarkable optical absorption and electrical performance such as small effective masses and long diffusion length. It was predicted by employing polycrystalline $\mathrm{Cs}_{2} \mathrm{Au}_{2} \mathrm{I}_{6}$ as an active layer in PSC, the short-circuit-current of $30 \mathrm{~mA} \mathrm{~cm}^{-2}$ and photoconversion efficiency of $20 \%$ could be obtained. They used full-wave electromagnetic simulations based on the finite element methods (FEM) to do their calculation.

In 2017, Ju et al. [139] introduced a new class of vacancy-ordered perovskite based on $\mathrm{Ti}^{4+}$ ion. Their experimental and theoretical results indicated that both $\mathrm{Cs}_{2} \mathrm{TiI}_{2} \mathrm{Br}_{4}$ and $\mathrm{Cs}_{2} \mathrm{TiBr}_{6}$ possessed the ideal bandgap values of $1.38 \mathrm{eV}$ for single junction and $1.78 \mathrm{eV}$ for tandem solar cells. Moreover, both materials exhibited good environmental stability. Sakai et al. [140], by employing DFT/GCA calculations showed that the electron and hole effective masses of $\mathrm{Cs}_{2} \mathrm{PdBr}_{6}$ were to be 0.53 and $0.85 \mathrm{~m}_{\mathrm{e}}$, respectively, which resulted in n-type semiconductivity in $\mathrm{Cs}_{2} \mathrm{PdBr}_{6}$. 
Table 6. Summary of prepared vacancy-ordered double halide perovskite samples.

\begin{tabular}{|c|c|c|c|c|c|c|c|c|}
\hline Compound & Morphology & Synthetic Method & $\begin{array}{l}\text { Optical } \\
\text { Transition }\end{array}$ & $\begin{array}{c}\text { Theoretical } \\
\text { Bandgap }\end{array}$ & $\begin{array}{l}\text { Experimental } \\
\text { Bandgap }\end{array}$ & $\begin{array}{c}\text { Characterization } \\
\text { Techniques }\end{array}$ & $\begin{array}{l}\text { Theoretical } \\
\text { Calculation }\end{array}$ & Reference \\
\hline $\mathrm{Rb}_{2} \mathrm{SnI}_{6}$ & Powder & $\begin{array}{c}\text { Solution } \\
\text { precipitation }\end{array}$ & Direct & $\begin{array}{c}1.13 \mathrm{eV} \text { and } \\
1.32 \mathrm{eV} \text { (depend } \\
\text { on the calculation) }\end{array}$ & $1.32 \mathrm{eV}$ & $\begin{array}{l}\text { XPDF, nPDF, UV-Vis } \\
\text { spectroscopy, PPMS, } \\
\text { SXRD, PXRD }\end{array}$ & $\begin{array}{l}\text { DFT-VASP, PAW, } \\
\text { PBEsol, HSE06, } \\
\text { HSE06+SOC, } \\
\text { DFPT }\end{array}$ & [106] \\
\hline $\mathrm{Cs}_{2} \mathrm{AuI}_{6}$ & - & - & Direct & $1.31 \mathrm{eV}$ & - & - & $\begin{array}{l}\text { DFT-VASP, PAW, } \\
\text { PBE, HSE }\end{array}$ & [138] \\
\hline $\mathrm{Cs}_{2} \mathrm{TiBr}_{6}$ & Powder & $\begin{array}{l}\text { melt- } \\
\text { crystallization } \\
\text { method }\end{array}$ & Indirect & $\begin{array}{c}2.01 \mathrm{eV}(\mathrm{HSE}) \\
1.89 \mathrm{eV} \\
(\mathrm{HSE}+\mathrm{SOC})\end{array}$ & $1.78 \mathrm{eV}$ & $\begin{array}{c}\text { UV-Vis spectroscopy, } \\
\text { XRD }\end{array}$ & $\begin{array}{l}\text { DFT-VASP, PAW, } \\
\text { HSE06 }\end{array}$ & [139] \\
\hline $\mathrm{Cs}_{2} \mathrm{TiI}_{2} \mathrm{Br}_{4}$ & Powder & $\begin{array}{l}\text { melt- } \\
\text { crystallization } \\
\text { method }\end{array}$ & Indirect & $\begin{array}{c}1.49 \mathrm{eV} \text { (HSE) } \\
1.32 \mathrm{ev} \\
(\mathrm{HSE}+\mathrm{SOC})\end{array}$ & $1.38 \mathrm{eV}$ & $\begin{array}{c}\text { UV-Vis spectroscopy, } \\
\text { XRD }\end{array}$ & $\begin{array}{l}\text { DFT-VASP, PAW, } \\
\text { HSE06 }\end{array}$ & [139] \\
\hline $\mathrm{Cs}_{2} \mathrm{TiI}_{6}$ & Powder & $\begin{array}{l}\text { melt- } \\
\text { crystallization } \\
\text { method }\end{array}$ & Indirect & $\begin{array}{c}1.20 \mathrm{eV} \text { (HSE) } \\
1.05 \mathrm{eV} \text { (HSE+SOC }\end{array}$ & $1.02 \mathrm{eV}$ & $\begin{array}{c}\text { UV-Vis spectroscopy, } \\
\text { XRD }\end{array}$ & $\begin{array}{l}\text { DFT-VASP, PAW, } \\
\text { HSE06 }\end{array}$ & [139] \\
\hline $\mathrm{Cs}_{2} \mathrm{TiI}_{4} \mathrm{Br}_{2}$ & Powder & $\begin{array}{l}\text { melt- } \\
\text { crystallization } \\
\text { method }\end{array}$ & Indirect & $\begin{array}{c}1.10 \mathrm{eV} \text { (HSE) } \\
1.00 \mathrm{eV} \text { (HSE+SOC }\end{array}$ & $1.15 \mathrm{eV}$ & $\begin{array}{c}\text { UV-Vis spectroscopy, } \\
\text { XRD }\end{array}$ & $\begin{array}{l}\text { DFT-VASP, PAW, } \\
\text { HSE06 }\end{array}$ & [139] \\
\hline $\begin{array}{c}\mathrm{Cs}_{2} \mathrm{Ti}\left(\mathrm{Br}_{x} \mathrm{Cl}_{1-x}\right)_{6} \\
(0<\mathrm{x}<1)\end{array}$ & Powder & $\begin{array}{l}\text { Solution-based } \\
\text { process using } \\
\text { hydrohalic acid }\end{array}$ & Quasi-direct & $\begin{array}{l}\sim 1.6 \mathrm{eV} \text { to } \\
\sim 2.3 \mathrm{eV}\end{array}$ & $\begin{array}{l}\sim 1.7 \mathrm{eV} \text { to } \\
\sim 2.5 \mathrm{eV}\end{array}$ & $\begin{array}{c}\text { SEM, EDS, XRD, TGA, } \\
\text { UV-Vis-NIR } \\
\text { spectroscopy, PL, PLQY }\end{array}$ & $\begin{array}{l}\text { DFT-CASTEP, } \\
\text { GGA-PBE }\end{array}$ & [141] \\
\hline
\end{tabular}




\subsection{2. $\mathrm{Cs}_{2} \mathrm{M}^{4+} \mathrm{X}_{6}$ : Experimental Results}

- $\quad \mathrm{Cs}_{2} \mathrm{M}^{4+} \mathrm{X}_{6}$ : Single-Crystals, Polycrystalline and Nanocrystals-Based Perovskites

Lee et al. [137] prepared $\mathrm{Cs}_{2} \mathrm{SnI}_{6}$ perovskite as a stable molecular iodosalt serving as a hole transporting layer in solid-state DSSCs. This iodosalt compound which Sn is on its +4-oxidation state showed high stability against moisture and air compared with $\mathrm{CsSnI}_{3}$ and $\mathrm{MASnI}_{3}$ perovskites.

In 2019, Kong et al. [141] adopted a solution-based process for synthesis of $\mathrm{Cs}_{2} \mathrm{TiX}_{6}$ $(\mathrm{x}=\mathrm{Cl}$ and $\mathrm{Br})$ at room temperature. The highly uniform and thermally stable crystals and thin film of $\mathrm{Cs}_{2} \mathrm{TiBr}_{\mathrm{x}} \mathrm{Cl}_{1-\mathrm{x}}(0<\mathrm{x}<1)$ were prepared. The obtained materials showed a quasi-direct bandgap of $1.7 \mathrm{eV}$ for $\mathrm{Cs}_{2} \mathrm{TiBr}_{6}, 1.95 \mathrm{eV}$ for $\mathrm{Cs}_{2} \mathrm{TiBr}_{2} \mathrm{Cl}_{4}$ and $2.5 \mathrm{eV}$ for $\mathrm{Cs}_{2} \mathrm{TiCl}_{6}$. Furthermore, steady-state PL exhibited an emission peak centered at $\sim 535 \mathrm{~nm}$ for $\mathrm{Cs}_{2} \mathrm{TiCl}_{6}, \sim 635 \mathrm{~nm}$ for $\mathrm{Cs}_{2} \mathrm{TiBr}_{2} \mathrm{Cl}_{4}$ and $\sim 670 \mathrm{~nm}$ for $\mathrm{Cs}_{2} \mathrm{TiBr}_{6}$. The FWHM values for all prepared samples were larger than $100 \mathrm{~nm}$, which is comparable with Pb-based perovskites. However, in order to obtain more efficient thin films and for engineering the bandgaps, they suggested different synthesis approaches and alloying with other metallics or halide elements were required. Sakai et al. [140] by employing the solution process technique, synthesized $\mathrm{Cs}_{2} \mathrm{PdBr}_{6}$ halide perovskite. During the synthesis process, the oxidation state of $\mathrm{Pd}^{2+}$ changed to $\mathrm{Pd}^{4+}$ which was generated in situ. The obtained compound crystallized in a cubic structure with a space group of $f m-3 m$. The optical measurements indicated that compound had an indirect bandgap of $1.6 \mathrm{eV}$. In order to study the sample photoconductivity a sandwich structure was fabricated including ITO/Cs ${ }_{2} \mathrm{PdBr}_{6} / \mathrm{Ag}$. The carried-out experiment confirmed the feasibility of $\mathrm{Cs}_{2} \mathrm{PdBr}_{6}$ perovskite for different optoelectronic applications such as LEDs, PV and photon-sensors.

- $\mathrm{Cs}_{2} \mathrm{M}^{4+} \mathrm{X}_{6}$ : Film-Based

Chen et al. [87], as already presented in Table 2, by employing the facile low-temperature vapor deposition methodology, prepared a high-quality thin film of $\mathrm{Cs}_{2} \mathrm{TiBr}_{6}$ halide perovskite. The synthesized thin film demonstrated an optimal bandgap of $1.78 \mathrm{eV}$ with a carrier diffusion length of more than $100 \mathrm{~nm}$.

\subsection{3. $\mathrm{Cs}_{2} \mathrm{M}^{4+} \mathrm{X}_{6}$ : Doping}

In 2016, the solid-solution of $\mathrm{Cs}_{2} \mathrm{Sn}_{1-x} \mathrm{Te}_{x} \mathrm{I}_{6}$ was prepared by Maughan et al. [136] in order to investigate of its structure-property relationship. The substitution of $\mathrm{Sn}$ by Te causing the increase of electronic dispersion due to the closer contact distances of I-I bonding resulted in reduction of conductivity, carrier mobility and carrier concentration. DFT calculation revealed the hindered formation of intrinsic iodine vacancy donor defects resulting in insulating characteristics of $\mathrm{Cs}_{2} \mathrm{TeI}_{6}$. However, the theoretical calculation of $\mathrm{Cs}_{2} \mathrm{SnI}_{6}$ native defects showed a low enthalpy of iodine vacancies formation and a level of defect energy that was a shallow donor to the conduction band. This makes the material tolerant to defect states. In Te-doped compound, the covalency of Te-I bonding suppresses the formation of iodine vacancy state causing the reduction in conductivity.

Maughan et al. [106] studied the electrical and structural changes created by substitution of $\mathrm{Cs}^{+}$with $\mathrm{Rb}^{+}$. Both $\mathrm{Cs}_{2} \mathrm{SnI}_{6}$ and $\mathrm{Rb}_{2} \mathrm{SnI}_{6}$ showed a native n-type semiconductivity. However, the replacement of $\mathrm{Cs}^{+}$with $\mathrm{Rb}^{+}$decreased the charge carrier mobility by $\sim 50$ times compared to $\mathrm{Cs}_{2} \mathrm{SnI}_{6}$ that makes $\mathrm{Cs}_{2} \mathrm{SnI}_{6}$ as an interesting material for optoelectronic applications.

In 2018, Tan et al. [107] selected vacancy-ordered $\mathrm{Cs}_{2} \mathrm{SnCl}_{6}$ perovskite as a host and $\mathrm{Bi}^{3+}$ as the luminescence dopant. The prepared $\mathrm{Cs}_{2} \mathrm{SnCl}_{6}$ : Bi perovskite showed an intense rise of PLQY (78.9\%) with an emission peak at $445 \mathrm{~nm}$. Furthermore, the doping of Bi resulted in narrowing of bandgap from $3.9 \mathrm{eV}$ in $\mathrm{Cs}_{2} \mathrm{SnCl}_{6}$ to $3.0 \mathrm{eV}$ in $\mathrm{Cs}_{2} \mathrm{SnCl}_{6}$ : Bi due to the generating of defect bands $\left[\mathrm{Bi}_{\mathrm{Sn}}+\mathrm{V}_{\mathrm{Cl}}\right]$. The formation of $\mathrm{BiOCl}$ layer as well as stable oxidation state of $\mathrm{Sn}^{4+}$ enhanced the thermal and water stability. Also, the combination of $\mathrm{Cs}_{2} \mathrm{SnCl}_{6}$ : Bi with commercial yellow phosphors along with commercial UV-LED chips 
led to high warm light emission with a correlated color temperature of $4486 \mathrm{~K}$ and a commission Internationale de I'Eclairage (CIE) coordinate of (036; 0.37).

In 2019, Ma et al. [108] studied the effect of $\mathrm{Ge}^{4+}$ substitution on $\mathrm{CsSn}_{1-\mathrm{x}} \mathrm{Ge}_{\mathrm{x}} \mathrm{I}_{6}(\mathrm{x}=0.25$, $0.5,0.75,1)$ properties. First-principle calculation demonstrated that the concentration of $\mathrm{Ge}^{4+}$ and the value of the bandgap had linear relationship. The crystal cells of traditional $\mathrm{ABX}_{3}$ perovskites were easily influenced by doping small cations which caused tilting and contraction of the cell [142]. In this study, doping of Ge did not result in tilting up the $\mathrm{BI}_{6}$ octahedra, but the contraction of crystal cell occurred, which gave rise to the reduction of bandgap. Employing DOS and PDOS calculations, it was shown that doping of $\mathrm{Ge}^{4+}$ led to the change in composition of CBM and the bandgap.

\subsection{4. $\mathrm{Cs}_{2} \mathrm{M}^{4+} \mathrm{X}_{6}$ : Applications}

\section{- Photovoltaic applications}

In 2017, Qui et al. [86], as already provided in Table 2, by developing a two-step sequential deposition method, prepared B- $\gamma-\mathrm{CsSnI}_{3}$ thin film for PV application. However, under the ambient environment the oxidation of Sn changed from 2+ to 4+, which resulted in vacancy-ordered air-stable $\mathrm{Cs}_{2} \mathrm{SnI}_{6}$ perovskite with a bandgap of $1.48 \mathrm{eV}$. The best power conversion efficiency of $0.96 \%$ was measured for PSC with perovskite film of $300 \mathrm{~nm}$ thickness, exhibiting the $\mathrm{V}_{\mathrm{oc}}$ of $0.51 \mathrm{~V}, \mathrm{~J}_{\mathrm{sc}}$ of $5.41 \mathrm{~mA} \mathrm{~cm}^{-2}$ and $\mathrm{FF}$ of 35 . The inefficient electron/hole extraction towards the electrodes was explained by the mismatched energybarrier between $\mathrm{TiO}_{2} /$ Perovskite/HTL layers resulting in poor efficiency of $\sim 1 \%$ as shown in Figure 24a-c.

(a)
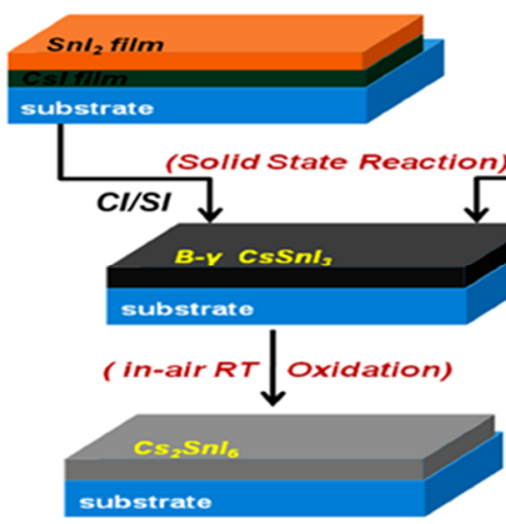

(d)

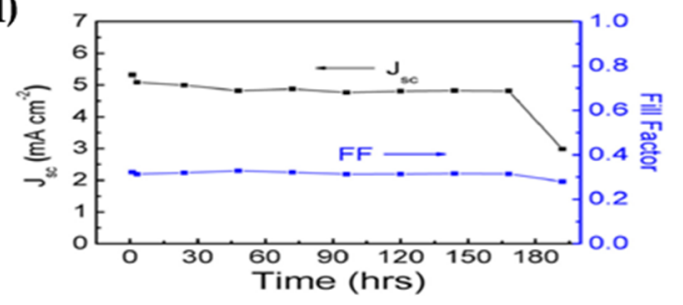

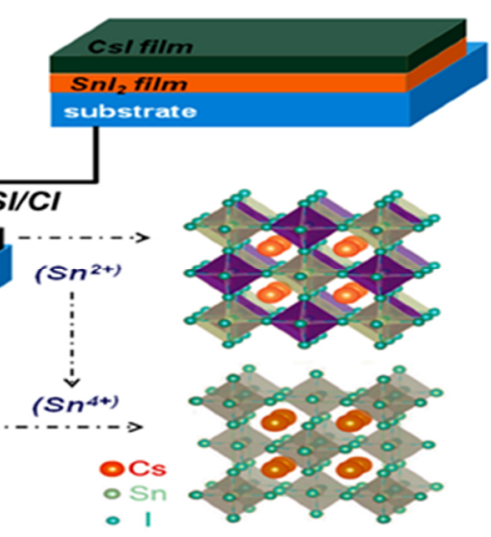

(b)

(c)
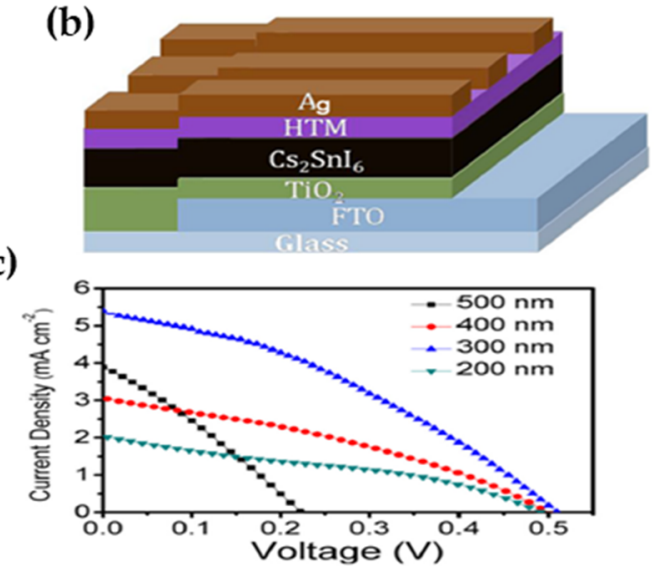

(e)

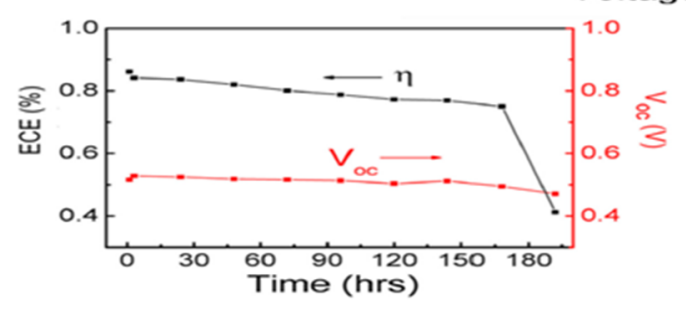

Figure 24. (a) Sketch of $\mathrm{Cs}_{2} \mathrm{SnI}_{6}$ film growth from $\mathrm{CsSnI}_{3}$ using wo-step deposition method through solid-state reaction; (b) sketch of the architecture for the $\mathrm{Cs}_{2} \mathrm{SnI}_{6}$ based perovskite solar cell; (c) J-V curves of perovskite solar cells fabricated with $\mathrm{Cs}_{2} \mathrm{SnI}_{6}$ of different thicknesses; (d,e) $\mathrm{Cs}_{2} \mathrm{SnI}_{6}$-based unsealed perovskite solar cell stability measurement of the main parameters as a function of time taken at specific time intervals. Reproduced with permission from [86]. Copyright 2017, Elsevier.

A Ti-based perovskite solar cell was fabricated first by Chen et al. [87]. The insertion of $\mathrm{C}_{60}$ between $\mathrm{TiO}_{2}$-ETL layer and $\mathrm{Cs}_{2} \mathrm{TiBr}_{6}$ resulted in promising efficiency of $3.3 \%$ with $\mathrm{V}_{\mathrm{oc}}$ of $1.02 \mathrm{~V}, \mathrm{~J}_{\mathrm{sc}}$ of $5.69 \mathrm{~mA} \mathrm{~cm}^{-2}$ and $\mathrm{FF}$ of 0.564 in a reverse scan. 


\section{Conclusions and Perspective}

Despite the significant power conversion efficiency of $\mathrm{Pb}$-based perovskites for $\mathrm{PV}$ applications, two main drawbacks including the instability and toxicity of $\mathrm{Pb}$ hinder their large-scale fabrication and commercialization. To develop non-toxic and air-stable photo- absorbers for PSCs, double halide perovskites with a formula of $\mathrm{A}_{2} \mathrm{M}^{+} \mathrm{M}^{3+} \mathrm{X}_{6}$ were suggested and investigated as a new design strategy.

In this review, theoretical and experimental results of $\mathrm{Cs}$-based $\mathrm{Pb}$-free double halide perovskites, influence of metal doping/alloying on selected perovskites along with current potential applications are highlighted. A thorough review of $\mathrm{Cs}_{2} \mathrm{M}^{+} \mathrm{M}^{3+} \mathrm{X}_{6}$ structures with special emphasis on $\left(\mathrm{Bi}^{3+}, \mathrm{In}^{3+}, \mathrm{Sb}^{3+}\right)$ as $\mathrm{M}^{3+}$ elements is carried out. In addition, Cs-based vacancy ordered double halide perovskites with formula of $\mathrm{Cs}_{2} \mathrm{M}^{4+} \mathrm{X}_{6}$ are also reviewed.

Based on the obtained results from different research methodologies and procedures, it is clear that Cs-based Pb-free double halide perovskites have enhanced thermal and ambient stability, but the bandgap values of these materials are not optimal for PV applications. However, many studies have demonstrated that bandgap of these materials could be tuned through metal doping/alloying.

Among the various studied $\mathrm{Cs}_{2} \mathrm{M}^{+} \mathrm{M}^{3+} \mathrm{X}_{6}$ structures, $\mathrm{Bi}^{3+}$-based double perovskites have shown promising features for PV applications with an estimated indirect bandgap varying from $\approx 1.7 \mathrm{eV}$ [56] to $2.89 \mathrm{eV}$ [59] which could be tuned from indirect to direct by metal doping [91]. Also, to the best of our knowledge, the latest study based on $\mathrm{Cs}_{2} \mathrm{AgBiBr}_{6}$ showed the best photovoltaic efficiency of 3.11\% [66] with unique features such as high environmental stability, low toxicity and long carrier recombination lifetime. Moreover, significant optical and electronic properties with remarkable performances, turn the $\mathrm{Cs}_{2} \mathrm{AgBiBr}_{6}$ into an outstanding candidate for other optoelectronic applications such as LEDs, UV detectors, $\mathrm{X}$-ray detectors etc. Processes related to employing appropriate coating methods and managing bulk engineering of $\mathrm{Cs}_{2} \mathrm{AgBiBr}_{6}$ structure, along with managing interface engineering by for example introducing interfacial layers between $\mathrm{ETL} / \mathrm{Cs}_{2} \mathrm{AgBiBr}_{6} / \mathrm{HTL}$ have to be concentrated for further enhancement of efficiency of PSCs based on this promising material.

Studies have revealed that $\mathrm{In}^{3+}$-based double perovskites have large direct bandgaps varying from $\approx 3.23 \mathrm{eV}$ to $3.57 \mathrm{eV}[85,124]$. It was indicated that the parity-induced forbidden transition in Cs $/ \mathrm{In}^{3+}$-based double halide perovskites causes the optical transition obstruction and makes these materials unsuitable for solar devices, but these materials showed inherent environmental stability against air/moisture. Also, it was shown through alloying of metal ions, not only the PL properties of Cs/In- based double halide perovskites were significantly enhanced, an important feature for LEDs, but also the large direct band gap of this compound was tuned from $\sim 3.5 \mathrm{eV}$ to $2.54 \mathrm{eV}$ [125].

The $\mathrm{Cs} / \mathrm{Sb}^{3+}$ double halide perovskites were shown to have large indirect bandgap varying from $\approx 1.64 \mathrm{eV}$ (single crystals) to $3.0 \mathrm{eV}[62,68]$, that hinders them of showing desirable $\mathrm{PV}$ performance. $\mathrm{Cs} / \mathrm{Sb}^{3+}$ double halide perovskites are thermodynamically unstable. Amongst vacancy-ordered lead-free double halide perovskites reviewed, $\mathrm{Cs}_{2} \mathrm{TiBr}_{6}$ showed the relatively higher efficiency of 3.3\% [87] along with high stability under ambient environment.

Our review shows that by employing different theoretical and experimental approaches in the studies has had a significant influence on the results which describe optoelectronic characteristics of Cs-based double halide perovskites. For example, it was shown that synthetic methodologies and conditions (temperature, the concentration of precursors, time, solvents) and employing different types of characterization instruments (UV-Vis spectroscopy vs. DRS) led to obtaining varying photophysical and structural results, so in order to reduce/eliminate these discrepancies, as this review clearly indicates, a combined theoretical and experimental approach will be the best way to get in-depth understanding of lead-free double halide perovskite materials. It also helps to address the issues like bandgap alignment, carrier and interfacial dynamics between perovskite and transporting layers. 
Furthermore, plenty of studies in order to employ suitable electrodes, HTL and ETL layers along with efficient interfacial layers could be carried out since these layers have a significant effect on PSCs' efficiency. Exploring more on Cs-based double perovskite materials especially on $\mathrm{Cs} / \mathrm{Bi}^{3+}$-based lead-free double halide perovskites may help the researchers to overcome the toxicity and instability challenges faced with lead-based perovskite materials for different applications in PV, photocatalysis, photodetectors, lightemitting devices etc.

Author Contributions: Conceptualization, F.H.G. and D.V.; methodology, F.H.G. and D.V.; writingoriginal draft preparation, F.H.G.; writing—review and editing, F.H.G. and D.V.; supervision, D.V. Both authors have read and agreed to the published version of the manuscript.

Funding: This research received no external funding.

Institutional Review Board Statement: Not Applicable.

Informed Consent Statement: Not Applicable.

Data Availability Statement: No new data were created or analyzed in this study. Data sharing is not applicable to this article.

Acknowledgments: We gratefully acknowledge funding provided by Western Norway University of Applied Sciences (HVL) for UTFORSK and NORPART project with ID numbers UTF- 2016long-term/10051 and NORPART-2016-10237.

Conflicts of Interest: The authors declare no conflict of interest.

\section{References}

1. Kojima, A.; Teshima, K.; Shirai, Y.; Miyasaka, T. Organometal halide perovskites as visible-light sensitizers for photovoltaic cells. J. Am. Chem. Soc. 2009, 131, 6050-6051. [CrossRef] [PubMed]

2. Kim, H.-S.; Lee, C.-R.; Im, J.-H.; Lee, K.-B.; Moehl, T.; Marchioro, A.; Moon, S.-J.; Humphry-Baker, R.; Yum, J.-H.; Moser, J.E. Lead iodide perovskite sensitized all-solid-state submicron thin film mesoscopic solar cell with efficiency exceeding 9\%. Sci. Rep. 2012, 2, 591. [CrossRef] [PubMed]

3. Park, N.G. Research direction toward scalable, stable, and high efficiency perovskite solar cells. Adv. Energy Mater. 2020, 10, 1903106. [CrossRef]

4. Seok, S.I.; Grätzel, M.; Park, N.G. Methodologies toward highly efficient perovskite solar cells. Small 2018, 14, 1704177. [CrossRef]

5. Chu, L.; Ahmad, W.; Liu, W.; Yang, J.; Zhang, R.; Sun, Y.; Yang, J.; Li, X.A. Lead-Free Halide Double Perovskite Materials: A New Superstar Toward Green and Stable Optoelectronic Applications. Nano-Micro Lett. 2019, 11, 16. [CrossRef]

6. Giustino, F.; Snaith, H.J. Toward lead-free perovskite solar cells. ACS Energy Lett. 2016, 1, 1233-1240. [CrossRef]

7. De Wolf, S.; Holovsky, J.; Moon, S.-J.; Löper, P.; Niesen, B.; Ledinsky, M.; Haug, F.-J.; Yum, J.-H.; Ballif, C. Organometallic halide perovskites: Sharp optical absorption edge and its relation to photovoltaic performance. J. Phys. Chem. Lett. 2014, 5, 1035-1039. [CrossRef]

8. Chin, X.Y.; Cortecchia, D.; Yin, J.; Bruno, A.; Soci, C. Lead iodide perovskite light-emitting field-effect transistor. Nat. Commun. 2015, 6, 7383. [CrossRef]

9. Huang, H.; Raith, J.; Kershaw, S.V.; Kalytchuk, S.; Tomanec, O.; Jing, L.; Susha, A.S.; Zboril, R.; Rogach, A.L. Growth mechanism of strongly emitting $\mathrm{CH}_{3} \mathrm{NH}_{3} \mathrm{PbBr}_{3}$ perovskite nanocrystals with a tunable bandgap. Nat. Commun. 2017, 8, 1-8. [CrossRef]

10. Tan, Z.-K.; Moghaddam, R.S.; Lai, M.L.; Docampo, P.; Higler, R.; Deschler, F.; Price, M.; Sadhanala, A.; Pazos, L.M.; Credgington, D. Bright light-emitting diodes based on organometal halide perovskite. Nat. Nanotechnol. 2014, 9, 687-692. [CrossRef]

11. Zhu, H.; Fu, Y.; Meng, F.; Wu, X.; Gong, Z.; Ding, Q.; Gustafsson, M.V.; Trinh, M.T.; Jin, S.; Zhu, X. Lead halide perovskite nanowire lasers with low lasing thresholds and high quality factors. Nat. Mater. 2015, 14, 636-642. [CrossRef] [PubMed]

12. Ramasamy, P.; Lim, D.-H.; Kim, B.; Lee, S.-H.; Lee, M.-S.; Lee, J.-S. All-inorganic cesium lead halide perovskite nanocrystals for photodetector applications. Chem. Commun. 2016, 52, 2067-2070. [CrossRef]

13. $\mathrm{Hu}, \mathrm{X} . ;$ Zhang, X.; Liang, L.; Bao, J.; Li, S.; Yang, W.; Xie, Y. High-performance flexible broadband photodetector based on organolead halide perovskite. Adv. Funct. Mater. 2014, 24, 7373-7380. [CrossRef]

14. Wei, H.; Fang, Y.; Mulligan, P.; Chuirazzi, W.; Fang, H.-H.; Wang, C.; Ecker, B.R.; Gao, Y.; Loi, M.A.; Cao, L. Sensitive X-ray detectors made of methylammonium lead tribromide perovskite single crystals. Nat. Photonics 2016, 10, 333. [CrossRef]

15. Hoefler, S.F.; Trimmel, G.; Rath, T. Progress on lead-free metal halide perovskites for photovoltaic applications: A review. Mon. Chem. Chem. Mon. 2017, 148, 795-826. [CrossRef]

16. Babayigit, A.; Ethirajan, A.; Muller, M.; Conings, B. Toxicity of organometal halide perovskite solar cells. Nat. Mater. 2016, 15, 247. [CrossRef] 
17. Fu, H. Review of lead-free halide perovskites as light-absorbers for photovoltaic applications: From materials to solar cells. Sol. Energy Mater. Sol. Cells 2019, 193, 107-132. [CrossRef]

18. Jaishankar, M.; Tseten, T.; Anbalagan, N.; Mathew, B.B.; Beeregowda, K.N. Toxicity, mechanism and health effects of some heavy metals. Interdiscip. Toxicol. 2014, 7, 60-72. [CrossRef]

19. Tchounwou, P.B.; Yedjou, C.G.; Patlolla, A.K.; Sutton, D.J. Heavy metal toxicity and the environment. In Molecular, Clinical and Environmental Toxicology; Springer: Berlin/Heidelberg, Germany, 2012; pp. 133-164.

20. Abate, A. Perovskite solar cells go lead free. Joule 2017, 1, 659-664. [CrossRef]

21. Aristidou, N.; Sanchez-Molina, I.; Chotchuangchutchaval, T.; Brown, M.; Martinez, L.; Rath, T.; Haque, S.A. The role of oxygen in the degradation of methylammonium lead trihalide perovskite photoactive layers. Angew. Chem. Int. Ed. 2015, 54, 8208-8212 [CrossRef]

22. Hailegnaw, B.; Kirmayer, S.; Edri, E.; Hodes, G.; Cahen, D. Rain on methylammonium lead iodide based perovskites: Possible environmental effects of perovskite solar cells. J. Phys. Chem. Lett. 2015, 6, 1543-1547. [CrossRef]

23. Habisreutinger, S.N.; McMeekin, D.P.; Snaith, H.J.; Nicholas, R.J. Research Update: Strategies for improving the stability of perovskite solar cells. APL Mater. 2016, 4, 091503. [CrossRef]

24. Heo, J.; Im, S.; Noh, J.; Madal, T.; Lim, C.; Chang, J.; Lee, Y.; Kim, H.; Sarkar, A.; Nazeeruddin, M.K. Efficient inorganic-organic hybrid heterojunction solar cells containing perovskite compound and polymeric hole conductors. Nano Lett. 2013, $13,1764$. [CrossRef]

25. Wang, Z.; Shi, Z.; Li, T.; Chen, Y.; Huang, W. Stability of perovskite solar cells: A prospective on the substitution of the A cation and X anion. Angew. Chem. Int. Ed. 2017, 56, 1190-1212. [CrossRef] [PubMed]

26. Emami, S.; Andrade, L.; Mendes, A. Recent progress in long-term stability of perovskite solar cells. U. Porto J. Eng. 2015, 1, 52-62. [CrossRef]

27. Liu, W.; Lin, Q.; Li, H.; Wu, K.; Robel, I.; Pietryga, J.M.; Klimov, V.I. Mn ${ }^{2+}$-doped lead halide perovskite nanocrystals with dual-color emission controlled by halide content. J. Am. Chem. Soc. 2016, 138, 14954-14961. [CrossRef]

28. Abdi-Jalebi, M.; Dar, M.I.; Sadhanala, A.; Senanayak, S.P.; Franckevičius, M.; Arora, N.; Hu, Y.; Nazeeruddin, M.K.; Zakeeruddin, S.M.; Grätzel, M. Impact of monovalent cation halide additives on the structural and optoelectronic properties of $\mathrm{CH}_{3} \mathrm{NH}_{3} \mathrm{PbI}_{3}$ perovskite. Adv. Energy Mater. 2016, 6, 1502472. [CrossRef]

29. Shahbazi, S.; Tsai, C.-M.; Narra, S.; Wang, C.-Y.; Shiu, H.-S.; Afshar, S.; Taghavinia, N.; Diau, E.W.-G. Ag doping of organometal lead halide perovskites: Morphology modification and p-type character. J. Phys. Chem. C 2017, 121, 3673-3679. [CrossRef]

30. Yang, Y.; Zou, X.; Pei, Y.; Bai, X.; Jin, W.; Chen, D. Effect of doping of NaI monovalent cation halide on the structural, morphological, optical and optoelectronic properties of $\mathrm{MAPbI}_{3}$ perovskite. J. Mater. Sci. Mater. Electron. 2018, 29, 205-210. [CrossRef]

31. Wu, M.-C.; Chen, W.-C.; Chan, S.-H.; Su, W.-F. The effect of strontium and barium doping on perovskite-structured energy materials for photovoltaic applications. Appl. Surf. Sci. 2018, 429, 9-15. [CrossRef]

32. Zhao, W.; Yang, D.; Yang, Z.; Liu, S.F. Zn-doping for reduced hysteresis and improved performance of methylammonium lead iodide perovskite hybrid solar cells. Mater. Today Energy 2017, 5, 205-213. [CrossRef]

33. Zhang, Z.; Ren, L.; Yan, H.; Guo, S.; Wang, S.; Wang, M.; Jin, K. Bandgap narrowing in Bi-doped $\mathrm{CH}_{3} \mathrm{NH}_{3} \mathrm{PbCl}_{3}$ perovskite single crystals and thin films. J. Phys. Chem. C 2017, 121, 17436-17441. [CrossRef]

34. Oku, T.; Ohishi, Y.; Suzuki, A. Effects of antimony addition to perovskite-type $\mathrm{CH}_{3} \mathrm{NH}_{3} \mathrm{PbI}_{3}$ photovoltaic devices. Chem. Lett. 2016, 45, 134-136. [CrossRef]

35. Grancini, G.; Roldán-Carmona, C.; Zimmermann, I.; Mosconi, E.; Lee, X.; Martineau, D.; Narbey, S.; Oswald, F.; De Angelis, F.; Graetzel, M. One-Year stable perovskite solar cells by 2D/3D interface engineering. Nat. Commun. 2017, 8, 1-8. [CrossRef]

36. Li, H.; Luo, T.; Zhang, S.; Sun, Z.; He, X.; Zhang, W.; Chang, H. Two-dimensional metal-halide perovskite-based optoelectronics: Synthesis, structure, properties and applications. Energy Environ. Mater. 2021, 4, 46-64. [CrossRef]

37. Qian, L.; Sun, Y.; Sun, M.; Fang, Z.; Li, L.; Xie, D.; Li, C.; Ding, L. 2D perovskite microsheets for high-performance photodetectors. J. Mater. Chem. C 2019, 7, 5353-5358. [CrossRef]

38. Tang, S.; Huang, S.; Wilson, G.J.; Ho-Baillie, A. Progress and Opportunities for Cs Incorporated Perovskite Photovoltaics. Trends Chem. 2020, 2, 638-653. [CrossRef]

39. Umari, P.; Mosconi, E.; De Angelis, F. Relativistic GW calculations on $\mathrm{CH}_{3} \mathrm{NH}_{3} \mathrm{PbI}_{3}$ and $\mathrm{CH}_{3} \mathrm{NH}_{3} \mathrm{SnI}_{3}$ perovskites for solar cell applications. Sci. Rep. 2014, 4, 4467. [CrossRef] [PubMed]

40. Yin, W.J.; Shi, T.; Yan, Y. Unique properties of halide perovskites as possible origins of the superior solar cell performance. Adv. Mater. 2014, 26, 4653-4658. [CrossRef]

41. Zhang, Q.; Hao, F.; Li, J.; Zhou, Y.; Wei, Y.; Lin, H. Perovskite solar cells: Must lead be replaced—And can it be done? Sci. Technol. Adv. Mater. 2018, 19, 425-442. [CrossRef]

42. Stoumpos, C.C.; Malliakas, C.D.; Kanatzidis, M.G. Semiconducting tin and lead iodide perovskites with organic cations: Phase transitions, high mobilities, and near-infrared photoluminescent properties. Inorg. Chem. 2013, 52, 9019-9038. [CrossRef]

43. Wu, B.; Zhou, Y.; Xing, G.; Xu, Q.; Garces, H.F.; Solanki, A.; Goh, T.W.; Padture, N.P.; Sum, T.C. Long minority-carrier diffusion length and low surface-recombination velocity in inorganic lead-free $\mathrm{CsSnI}_{3}$ perovskite crystal for solar cells. Adv. Funct. Mater. 2017, 27, 1604818. [CrossRef] 
44. Noel, N.K.; Stranks, S.D.; Abate, A.; Wehrenfennig, C.; Guarnera, S.; Haghighirad, A.-A.; Sadhanala, A.; Eperon, G.E.; Pathak, S.K.; Johnston, M.B. Lead-free organic-inorganic tin halide perovskites for photovoltaic applications. Energy Environ. Sci. 2014, 7, 3061-3068. [CrossRef]

45. Hebig, J.-C.; Kühn, I.; Flohre, J.; Kirchartz, T. Optoelectronic properties of (CH3NH3) 3Sb2I9 thin films for photovoltaic applications. ACS Energy Lett. 2016, 1, 309-314. [CrossRef]

46. Pazoki, M.; Edvinsson, T. Metal replacement in perovskite solar cell materials: Chemical bonding effects and optoelectronic properties. Sustain. Energy Fuels 2018, 2, 1430-1445. [CrossRef]

47. Singh, T.; Kulkarni, A.; Ikegami, M.; Miyasaka, T. Effect of electron transporting layer on bismuth-based lead-free perovskite $\left(\mathrm{CH}_{3} \mathrm{NH}_{3}\right)_{3} \mathrm{Bi}_{2} \mathrm{I}_{9}$ for photovoltaic applications. ACS Appl. Mater. Interfaces 2016, 8, 14542-14547. [CrossRef] [PubMed]

48. Slavney, A.H.; Hu, T.; Lindenberg, A.M.; Karunadasa, H.I. A bismuth-halide double perovskite with long carrier recombination lifetime for photovoltaic applications. J. Am. Chem. Soc. 2016, 138, 2138-2141. [CrossRef] [PubMed]

49. McClure, E.T.; Ball, M.R.; Windl, W.; Woodward, P.M. Cs2AgBiX6 (X= Br, Cl): New visible light absorbing, lead-free halide perovskite semiconductors. Chem. Mater. 2016, 28, 1348-1354. [CrossRef]

50. Volonakis, G.; Filip, M.R.; Haghighirad, A.A.; Sakai, N.; Wenger, B.; Snaith, H.J.; Giustino, F. Lead-free halide double perovskites via heterovalent substitution of noble metals. J. Phys. Chem. Lett. 2016, 7, 1254-1259. [CrossRef]

51. Xiao, Z.; Meng, W.; Wang, J.; Mitzi, D.B.; Yan, Y. Searching for promising new perovskite-based photovoltaic absorbers: The importance of electronic dimensionality. Mater. Horiz. 2017, 4, 206-216. [CrossRef]

52. Kangsabanik, J.; Sugathan, V.; Yadav, A.; Yella, A.; Alam, A. Double perovskites overtaking the single perovskites: A set of new solar harvesting materials with much higher stability and efficiency. Phys. Rev. Mater. 2018, 2, 055401. [CrossRef]

53. Meng, W.; Wang, X.; Xiao, Z.; Wang, J.; Mitzi, D.B.; Yan, Y. Parity-forbidden transitions and their impact on the optical absorption properties of lead-free metal halide perovskites and double perovskites. J. Phys. Chem. Lett. 2017, 8, 2999-3007. [CrossRef]

54. Zhao, X.-G.; Yang, J.-H.; Fu, Y.; Yang, D.; Xu, Q.; Yu, L.; Wei, S.-H.; Zhang, L. Design of lead-free inorganic halide perovskites for solar cells via cation-transmutation. J. Am. Chem. Soc. 2017, 139, 2630-2638. [CrossRef]

55. Mohan, R. Green bismuth. Nat. Chem. 2010, 2, 336. [CrossRef] [PubMed]

56. Li, Q.; Wang, Y.; Pan, W.; Yang, W.; Zou, B.; Tang, J.; Quan, Z. High-Pressure Band-Gap Engineering in Lead-Free Cs $2 \mathrm{AgBiBr}_{6}$ Double Perovskite. Angew. Chem. Int. Ed. 2017, 56, 15969-15973. [CrossRef] [PubMed]

57. Filip, M.R.; Hillman, S.; Haghighirad, A.A.; Snaith, H.J.; Giustino, F. Band gaps of the lead-free halide double perovskites $\mathrm{Cs}_{2} \mathrm{BiAgCl}_{6}$ and $\mathrm{Cs}_{2} \mathrm{BiAgBr}_{6}$ from theory and experiment. J. Phys. Chem. Lett. 2016, 7, 2579-2585. [CrossRef] [PubMed]

58. Yang, J.; Zhang, P.; Wei, S.-H. Band structure engineering of $\mathrm{Cs}_{2} \mathrm{AgBiBr}_{6}$ perovskite through order-disordered transition: A first-principle study. J. Phys. Chem. Lett. 2018, 9, 31-35. [CrossRef]

59. Bekenstein, Y.; Dahl, J.C.; Huang, J.; Osowiecki, W.T.; Swabeck, J.K.; Chan, E.M.; Yang, P.; Alivisatos, A.P. The making and breaking of lead-free double perovskite nanocrystals of cesium silver-bismuth halide compositions. Nano Lett. 2018, 18, 3502-3508. [CrossRef]

60. Hoye, R.L.; Eyre, L.; Wei, F.; Brivio, F.; Sadhanala, A.; Sun, S.; Li, W.; Zhang, K.H.; MacManus-Driscoll, J.L.; Bristowe, P.D. Fundamental carrier lifetime exceeding $1 \mu \mathrm{s}$ in $\mathrm{Cs}_{2} \mathrm{AgBiBr}_{6}$ double perovskite. Adv. Mater. Interfaces 2018, 5, 1800464. [CrossRef]

61. Zelewski, S.; Urban, J.; Surrente, A.; Maude, D.; Kuc, A.; Schade, L.; Johnson, R.; Dollmann, M.; Nayak, P.; Snaith, H. Revealing the nature of photoluminescence emission in the metal-halide double perovskite $\mathrm{Cs}_{2} \mathrm{AgBiBr}_{6}$. J. Mater. Chem. C 2019, 7, 8350-8356. [CrossRef]

62. Wei, F.; Deng, Z.; Sun, S.; Hartono, N.T.P.; Seng, H.L.; Buonassisi, T.; Bristowe, P.D.; Cheetham, A.K. Enhanced visible light absorption for lead-free double perovskite $\mathrm{Cs}_{2} \mathrm{AgSbBr}_{6}$. Chem. Commun. 2019, 55, 3721-3724. [CrossRef]

63. García-Espejo, G.; Rodríguez-Padrón, D.; Luque, R.; Camacho, L.; de Miguel, G. Mechanochemical synthesis of three double perovskites: $\mathrm{Cs}_{2} \mathrm{AgBiBr}_{6},\left(\mathrm{CH}_{3} \mathrm{NH}_{3}\right)_{2} \mathrm{TlBiBr}_{6}$ and $\mathrm{Cs}_{2} \mathrm{AgSbBr}_{6}$. Nanoscale 2019, 11, 16650-16657. [CrossRef]

64. Wang, B.; Yang, L.; Dall'Agnese, C.; Jena, A.K.; Sasaki, S.-I.; Miyasaka, T.; Tamiaki, H.; Wang, X.-F. Photoactive Zn-chlorophyll hole transporter-sensitized lead-free $\mathrm{Cs}_{2} \mathrm{AgBiBr}_{6}$ perovskite solar cells. Sol. $R R L$ 2020, 4, 2000166. [CrossRef]

65. Yang, X.; Chen, Y.; Liu, P.; Xiang, H.; Wang, W.; Ran, R.; Zhou, W.; Shao, Z. Simultaneous Power Conversion Efficiency and Stability Enhancement of $\mathrm{Cs}_{2} \mathrm{AgBiBr}_{6}$ Lead-Free Inorganic Perovskite Solar Cell through Adopting a Multifunctional Dye Interlayer. Adv. Funct. Mater. 2020, 30, 2001557. [CrossRef]

66. Wang, B.; Li, N.; Yang, L.; Dall'Agnese, C.; Jena, A.K.; Sasaki, S.-I.; Miyasaka, T.; Tamiaki, H.; Wang, X.-F. Chlorophyll DerivativeSensitized $\mathrm{TiO}_{2}$ Electron Transport Layer for Record Efficiency of $\mathrm{Cs}_{2} \mathrm{AgBiBr}_{6}$ Double Perovskite Solar Cells. J. Am. Chem. Soc. 2021, 143, 2207-2211. [CrossRef]

67. Xiao, Z.; Du, K.-Z.; Meng, W.; Wang, J.; Mitzi, D.B.; Yan, Y. Intrinsic instability of $\mathrm{Cs}_{2} \operatorname{In}(\mathrm{I}) \mathrm{M}(\mathrm{III}) \mathrm{X}_{6}(\mathrm{M}=\mathrm{Bi}$, Sb; X = halogen) double perovskites: A combined density functional theory and experimental study. J. Am. Chem. Soc. 2017, 139, 6054-6057. [CrossRef]

68. Lin, Y.-P.; Hu, S.; Xia, B.; Fan, K.-Q.; Gong, L.-K.; Kong, J.-T.; Huang, X.-Y.; Xiao, Z.; Du, K.-Z. Material Design and Optoelectronic Properties of Three-Dimensional Quadruple Perovskite Halides. J. Phys. Chem. Lett. 2019, 10, 5219-5225. [CrossRef]

69. Xiao, Z.; Meng, W.; Wang, J.; Yan, Y. Thermodynamic Stability and Defect Chemistry of Bismuth-Based Lead-Free Double Perovskites. ChemSusChem 2016, 9, 2628-2633. [CrossRef] [PubMed]

70. Dronskowski, R. $\mathrm{In}_{3} \mathrm{Ti}_{2} \mathrm{Br}_{9}$ : Jahn-Teller Unstable Indium (i) and Antiferromagnetically Coupled Titanium (iii) Atoms. Chem. Eur. J. 1995, 1, 118-123. [CrossRef] 
71. Van den Berg, J.M. The crystal structure of the room temperature modification of indium chloride, InCl. Acta Crystallogr. 1966, 20, 905-910. [CrossRef]

72. Li, B.; Bian, K.; Zhou, X.; Lu, P.; Liu, S.; Brener, I.; Sinclair, M.; Luk, T.; Schunk, H.; Alarid, L. Pressure compression of CdSe nanoparticles into luminescent nanowires. Sci. Adv. 2017, 3, e1602916. [CrossRef]

73. Protesescu, L.; Yakunin, S.; Bodnarchuk, M.I.; Krieg, F.; Caputo, R.; Hendon, C.H.; Yang, R.X.; Walsh, A.; Kovalenko, M.V. Nanocrystals of cesium lead halide perovskites $\left(\mathrm{CsPbX}_{3}, \mathrm{X}=\mathrm{Cl}, \mathrm{Br}\right.$, and I): Novel optoelectronic materials showing bright emission with wide color gamut. Nano Lett. 2015, 15, 3692-3696. [CrossRef]

74. Xu, K.; Lin, C.C.; Xie, X.; Meijerink, A. Efficient and stable luminescence from $\mathrm{Mn}^{2+}$ in core and core-isocrystalline shell CsPbCl 3 perovskite nanocrystals. Chem. Mater. 2017, 29, 4265-4272. [CrossRef]

75. Zhang, C.; Gao, L.; Teo, S.; Guo, Z.; Xu, Z.; Zhao, S.; Ma, T. Design of a novel and highly stable lead-free $\mathrm{Cs}_{2} \mathrm{NaBiI}_{6} \mathrm{double}$ perovskite for photovoltaic application. Sustain. Energy Fuels 2018, 2, 2419-2428. [CrossRef]

76. Pelant, I.; Valenta, J. Luminescence Spectroscopy of Semiconductors; Oxford University Press: Oxford, UK, 2012.

77. Greul, E.; Petrus, M.L.; Binek, A.; Docampo, P.; Bein, T. Highly stable, phase pure $\mathrm{Cs}_{2} \mathrm{AgBiBr}_{6}$ double perovskite thin films for optoelectronic applications. J. Mater. Chem. A 2017, 5, 19972-19981. [CrossRef]

78. Wu, C.; Zhang, Q.; Liu, Y.; Luo, W.; Guo, X.; Huang, Z.; Ting, H.; Sun, W.; Zhong, X.; Wei, S. The Dawn of Lead-Free Perovskite Solar Cell: Highly Stable Double Perovskite $\mathrm{Cs}_{2} \mathrm{AgBiBr}_{6}$ Film. Adv. Sci. 2018, 5, 1700759. [CrossRef]

79. Ning, W.; Wang, F.; Wu, B.; Lu, J.; Yan, Z.; Liu, X.; Tao, Y.; Liu, J.M.; Huang, W.; Fahlman, M. Long Electron-Hole Diffusion Length in High-Quality Lead-Free Double Perovskite Films. Adv. Mater. 2018, 30, 1706246. [CrossRef]

80. Pantaler, M.; Cho, K.T.; Queloz, V.I.; Garcipa Benito, I.S.; Fettkenhauer, C.; Anusca, I.; Nazeeruddin, M.K.; Lupascu, D.C.; Grancini, G. Hysteresis-free lead-free double-perovskite solar cells by interface engineering. ACS Energy Lett. 2018, 3, 1781-1786. [CrossRef]

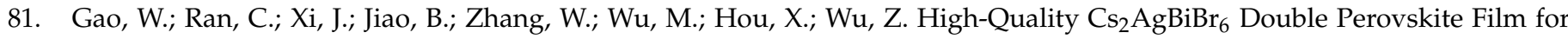
Lead-Free Inverted Planar Heterojunction Solar Cells with 2.2\% Efficiency. ChemPhysChem 2018, 19, 1696-1700. [CrossRef]

82. Wang, M.; Zeng, P.; Bai, S.; Gu, J.; Li, F.; Yang, Z.; Liu, M. High-Quality Sequential-Vapor-Deposited Cs ${ }_{2} \mathrm{AgBiBr}_{6} \mathrm{Thin}_{\mathrm{B}}$ Films for Lead-Free Perovskite Solar Cells. Sol. RRL 2018, 2, 1800217. [CrossRef]

83. Igbari, F.; Wang, R.; Wang, Z.-K.; Ma, X.-J.; Wang, Q.; Wang, K.-L.; Zhang, Y.; Liao, L.-S.; Yang, Y. Composition stoichiometry of $\mathrm{Cs}_{2} \mathrm{AgBiBr}_{6}$ films for highly efficient lead-free perovskite solar cells. Nano Lett. 2019, 19, 2066-2073. [CrossRef]

84. Zhang, Z.; Wu, C.; Wang, D.; Liu, G.; Zhang, Q.; Luo, W.; Qi, X.; Guo, X.; Zhang, Y.; Lao, Y. Improvement of $\mathrm{Cs}_{2} \mathrm{AgBiBr}_{6} \mathrm{double}$ perovskite solar cell by rubidium doping. Org. Electron. 2019, 74, 204-210. [CrossRef]

85. Dahl, J.C.; Osowiecki, W.T.; Cai, Y.; Swabeck, J.K.; Bekenstein, Y.; Asta, M.; Chan, E.M.; Alivisatos, A.P. Probing the stability and band gaps of $\mathrm{Cs}_{2} \mathrm{AgInCl}_{6}$ and $\mathrm{Cs}_{2} \mathrm{AgSbCl}_{6}$ lead-free double perovskite nanocrystals. Chem. Mater. 2019, 31, 3134-3143. [CrossRef]

86. Qiu, X.; Cao, B.; Yuan, S.; Chen, X.; Qiu, Z.; Jiang, Y.; Ye, Q.; Wang, H.; Zeng, H.; Liu, J. From unstable CsSnI3 to air-stable Cs 2 SnI 6 : A lead-free perovskite solar cell light absorber with bandgap of $1.48 \mathrm{eV}$ and high absorption coefficient. Sol. Energy Mater. Sol. Cells 2017, 159, 227-234. [CrossRef]

87. Chen, M.; Ju, M.-G.; Carl, A.D.; Zong, Y.; Grimm, R.L.; Gu, J.; Zeng, X.C.; Zhou, Y.; Padture, N.P. Cesium titanium (IV) bromide thin films based stable lead-free perovskite solar cells. Joule 2018, 2, 558-570. [CrossRef]

88. Arora, N.; Dar, M.I.; Hinderhofer, A.; Pellet, N.; Schreiber, F.; Zakeeruddin, S.M.; Grätzel, M. Perovskite solar cells with CuSCN hole extraction layers yield stabilized efficiencies greater than 20\%. Science 2017, 358, 768-771. [CrossRef]

89. Khalfin, S.; Bekenstein, Y. Advances in lead-free double perovskite nanocrystals, engineering band-gaps and enhancing stability through composition tunability. Nanoscale 2019, 11, 8665-8679. [CrossRef]

90. Xu, L.; Yuan, S.; Zeng, H.; Song, J. A comprehensive review of doping in perovskite nanocrystals/quantum dots: Evolution of structure, electronics, optics and light-emitting diodes. Mater. Today Nano 2019, 100036. [CrossRef]

91. Slavney, A.H.; Leppert, L.; Bartesaghi, D.; Gold-Parker, A.; Toney, M.F.; Savenije, T.J.; Neaton, J.B.; Karunadasa, H.I. Defectinduced band-edge reconstruction of a bismuth-halide double perovskite for visible-light absorption. J. Am. Chem. Soc. 2017, 139, 5015-5018. [CrossRef]

92. Du, K.z.; Meng, W.; Wang, X.; Yan, Y.; Mitzi, D.B. Bandgap Engineering of Lead-Free Double Perovskite $\mathrm{Cs}_{2} \mathrm{AgBiBr}_{6}$ through Trivalent Metal Alloying. Angew. Chem. Int. Ed. 2017, 56, 8158-8162. [CrossRef]

93. Yang, B.; Mao, X.; Hong, F.; Meng, W.; Tang, Y.; Xia, X.; Yang, S.; Deng, W.; Han, K. Lead-free direct band gap double-perovskite nanocrystals with bright dual-color emission. J. Am. Chem. Soc. 2018, 140, 17001-17006. [CrossRef]

94. Majher, J.D.; Gray, M.B.; Strom, T.A.; Woodward, P.M. Cs2NaBiCl6: Mn2+-A New Orange-Red Halide Double Perovskite Phosphor. Chem. Mater. 2019, 31, 1738-1744. [CrossRef]

95. Yao, M.M.; Wang, L.; Yao, J.S.; Wang, K.H.; Chen, C.; Zhu, B.S.; Yang, J.N.; Wang, J.J.; Xu, W.P.; Zhang, Q. Improving Lead-Free Double Perovskite Cs2NaBiCl6 Nanocrystal Optical Properties via Ion Doping. Adv. Opt. Mater. 2020, 8, 1901919. [CrossRef]

96. Nag, A. Synthesis and luminescence of Mn-doped $\mathrm{Cs}_{2} \mathrm{AgInCl}_{6}$ double perovskites. Chem. Commun. 2018, 54, 5205-5208.

97. Locardi, F.; Cirignano, M.; Baranov, D.; Dang, Z.; Prato, M.; Drago, F.; Ferretti, M.; Pinchetti, V.; Fanciulli, M.; Brovelli, S. Colloidal synthesis of double perovskite $\mathrm{Cs}_{2} \mathrm{AgInCl}_{6}$ and $\mathrm{Mn}$-doped $\mathrm{Cs}_{2} \mathrm{AgInCl}_{6}$ nanocrystals. J. Am. Chem. Soc. 2018, 140, 12989-12995. [CrossRef]

98. Hu, Q.; Niu, G.; Zheng, Z.; Li, S.; Zhang, Y.; Song, H.; Zhai, T.; Tang, J. Tunable Color Temperatures and Efficient White Emission from Cs2Ag1- xNaxIn1- yBiyCl6 Double Perovskite Nanocrystals. Small 2019, 15, 1903496. [CrossRef] 
99. Liu, Y.; Jing, Y.; Zhao, J.; Liu, Q.; Xia, Z. Design optimization of lead-free perovskite $\mathrm{Cs}_{2} \mathrm{AgInCl}_{6}$ : Bi nanocrystals with $11.4 \%$ photoluminescence quantum yield. Chem. Mater. 2019, 31, 3333-3339. [CrossRef]

100. Mahor, Y.; Mir, W.J.; Nag, A. Synthesis and near-infrared emission of Yb-doped $\mathrm{Cs}_{2} \mathrm{AgInCl}_{6}$ double perovskite microcrystals and nanocrystals. J. Phys. Chem. C 2019, 123, 15787-15793. [CrossRef]

101. Gray, M.; Hariyani, S.; Strom, A.; Majher, J.; Brgoch, J.; Woodward, P. High-Efficiency Blue Photoluminescence in the Cs $2 \mathrm{NaInCl}$ 6: Sb 3+ Double Perovskite Phosphor. J. Mater. Chem. C 2020, 8, 6797-6803. [CrossRef]

102. Zeng, R.; Zhang, L.; Xue, Y.; Ke, B.; Zhao, Z.; Huang, D.; Wei, Q.; Zhou, W.; Zou, B. Highly Efficient Blue Emission from Self-Trapped Excitons in Stable Sb3+-Doped Cs2NaInCl6 Double Perovskites. J. Phys. Chem. Lett. 2020, 11, 2053-2061. [CrossRef]

103. Karmakar, A.; Dodd, M.S.; Agnihotri, S.; Ravera, E.; Michaelis, V.K. Cu (II)-doped Cs2SbAgCl6 double perovskite: A lead-free, low-bandgap material. Chem. Mater. 2018, 30, 8280-8290. [CrossRef]

104. Kshirsagar, A.S.; Nag, A. Synthesis and optical properties of colloidal $\mathrm{Cs}_{2} \mathrm{AgSb}_{1-\mathrm{x}} \mathrm{BixCl}_{6}$ double perovskite nanocrystals. J. Chem. Phys. 2019, 151, 161101. [CrossRef]

105. Yang, B.; Hong, F.; Chen, J.; Tang, Y.; Yang, L.; Sang, Y.; Xia, X.; Guo, J.; He, H.; Yang, S. Colloidal Synthesis and Charge-Carrier Dynamics of Cs2AgSb1- yBiyX6 (X: Br, Cl; $0 \leq \mathrm{y} \leq 1)$ Double Perovskite Nanocrystals. Angew. Chem. 2019, 131, $2300-2305$. [CrossRef]

106. Maughan, A.E.; Ganose, A.M.; Almaker, M.A.; Scanlon, D.O.; Neilson, J.R. Tolerance factor and cooperative tilting effects in vacancy-ordered double perovskite halides. Chem. Mater. 2018, 30, 3909-3919. [CrossRef]

107. Tan, Z.; Li, J.; Zhang, C.; Li, Z.; Hu, Q.; Xiao, Z.; Kamiya, T.; Hosono, H.; Niu, G.; Lifshitz, E. Highly Efficient Blue-Emitting Bi-Doped Cs2SnCl6 Perovskite Variant: Photoluminescence Induced by Impurity Doping. Adv. Funct. Mater. 2018, $28,1801131$. [CrossRef]

108. Ma, X.X.; Li, Z.S. Influence of Sn/Ge Cation Exchange on Vacancy-Ordered Double Perovskite $\mathrm{Cs}_{2} \mathrm{Sn}_{(1-\mathrm{x})} \mathrm{GexI}_{6}$ : A First-Principles Theoretical Study. Phys. Status Solidi (B) 2019, 256, 1800427. [CrossRef]

109. Wang, F.; Bai, S.; Tress, W.; Hagfeldt, A.; Gao, F. Defects engineering for high-performance perovskite solar cells. NPJ Flex. Electron. 2018, 2, 1-14. [CrossRef]

110. Volonakis, G.; Giustino, F. Surface properties of lead-free halide double perovskites: Possible visible-light photo-catalysts for water splitting. Appl. Phys. Lett. 2018, 112, 243901. [CrossRef]

111. Pan, W.; Wu, H.; Luo, J.; Deng, Z.; Ge, C.; Chen, C.; Jiang, X.; Yin, W.-J.; Niu, G.; Zhu, L. Cs ${ }_{2} \mathrm{AgBiBr}_{6}$ single-crystal X-ray detectors with a low detection limit. Nat. Photonics 2017, 11, 726-732. [CrossRef]

112. Yuan, W.; Niu, G.; Xian, Y.; Wu, H.; Wang, H.; Yin, H.; Liu, P.; Li, W.; Fan, J. In Situ Regulating the Order-Disorder Phase Transition in $\mathrm{Cs}_{2} \mathrm{AgBiBr}_{6}$ Single Crystal toward the Application in an X-ray Detector. Adv. Funct. Mater. 2019, 29, 1900234. [CrossRef]

113. Li, H.; Shan, X.; Neu, J.N.; Geske, T.; Davis, M.; Mao, P.; Xiao, K.; Siegrist, T.; Yu, Z. Lead-free halide double perovskite-polymer composites for flexible X-ray imaging. J. Mater. Chem. C 2018, 6, 11961-11967. [CrossRef]

114. Lei, L.-Z.; Shi, Z.-F.; Li, Y.; Ma, Z.-Z.; Zhang, F.; Xu, T.-T.; Tian, Y.-T.; Wu, D.; Li, X.-J.; Du, G.-T. High-efficiency and air-stable photodetectors based on lead-free double perovskite $\mathrm{Cs}_{2} \mathrm{AgBiBr}_{6}$ thin films. J. Mater. Chem. C 2018, 6, 7982-7988. [CrossRef]

115. Wu, C.; Du, B.; Luo, W.; Liu, Y.; Li, T.; Wang, D.; Guo, X.; Ting, H.; Fang, Z.; Wang, S. Highly efficient and stable self-powered ultraviolet and deep-blue photodetector based on $\mathrm{Cs}_{2} \mathrm{AgBiBr}_{6} / \mathrm{SnO} 2$ heterojunction. Adv. Opt. Mater. 2018, 6, 1800811. [CrossRef]

116. Zhou, L.; Xu, Y.F.; Chen, B.X.; Kuang, D.B.; Su, C.Y. Synthesis and Photocatalytic Application of Stable Lead-Free Cs $2 \mathrm{AgBiBr}_{6}$ Perovskite Nanocrystals. Small 2018, 14, 1703762. [CrossRef]

117. Zhang, Z.; Liang, Y.; Huang, H.; Liu, X.; Li, Q.; Chen, L.; Xu, D. Stable and Highly Efficient Photocatalysis with Lead-Free Double-Perovskite of $\mathrm{Cs}_{2} \mathrm{AgBiBr}_{6}$. Angew. Chem. Int. Ed. 2019, 58, 7263-7267. [CrossRef]

118. Volonakis, G.; Haghighirad, A.A.; Milot, R.L.; Sio, W.H.; Filip, M.R.; Wenger, B.; Johnston, M.B.; Herz, L.M.; Snaith, H.J.; Giustino, F. $\mathrm{Cs}_{2} \operatorname{InAgCl}{ }_{6}$ : A new lead-free halide double perovskite with direct band gap. J. Phys. Chem. Lett. 2017, 8, 772-778. [CrossRef]

119. Zhao, X.-G.; Yang, D.; Sun, Y.; Li, T.; Zhang, L.; Yu, L.; Zunger, A. Cu-In halide perovskite solar absorbers. J. Am. Chem. Soc. 2017, 139, 6718-6725. [CrossRef]

120. Chirilă, A.; Buecheler, S.; Pianezzi, F.; Bloesch, P.; Gretener, C.; Uhl, A.R.; Fella, C.; Kranz, L.; Perrenoud, J.; Seyrling, S. Highly efficient $\mathrm{Cu}(\mathrm{In}, \mathrm{Ga}) \mathrm{Se}_{2}$ solar cells grown on flexible polymer films. Nat. Mater. 2011, 10, 857-861. [CrossRef]

121. Zhang, S.; Wei, S.-H.; Zunger, A.; Katayama-Yoshida, H. Defect physics of the CuInSe ${ }_{2}$ chalcopyrite semiconductor. Phys. Rev. B 1998, 57, 9642. [CrossRef]

122. Persson, C.; Zunger, A. Anomalous Grain Boundary Physics in Polycrystalline CuInSe 2 : The Existence of a Hole Barrier. Phys. Rev. Lett. 2003, 91, 266401. [CrossRef]

123. Xu, J.; Liu, J.-B.; Liu, B.-X.; Huang, B. Intrinsic defect physics in indium-based lead-free halide double perovskites. J. Phys. Chem. Lett. 2017, 8, 4391-4396. [CrossRef]

124. Zhou, J.; Xia, Z.; Molokeev, M.S.; Zhang, X.; Peng, D.; Liu, Q. Composition design, optical gap and stability investigations of lead-free halide double perovskite $\mathrm{Cs}_{2} \mathrm{AgInCl}_{6}$. J. Mater. Chem. A 2017, 5, 15031-15037. [CrossRef]

125. Tran, T.T.; Panella, J.R.; Chamorro, J.R.; Morey, J.R.; McQueen, T.M. Designing indirect-direct bandgap transitions in double perovskites. Mater. Horiz. 2017, 4, 688-693. [CrossRef]

126. Wu, W.; Cong, W.-Y.; Guan, C.; Sun, H.; Yin, R.; Yu, G.; Lu, Y.-B. Investigation of the Mn dopant-enhanced photoluminescence performance of lead-free $\mathrm{Cs}_{2} \mathrm{AgInCl}_{6}$ double perovskite crystals. Phys. Chem. Chem. Phys. 2020, 22, 1815-1819. [CrossRef] 
127. Luo, J.; Li, S.; Wu, H.; Zhou, Y.; Li, Y.; Liu, J.; Li, J.; Li, K.; Yi, F.; Niu, G. $\mathrm{Cs}_{2} \mathrm{AgInCl}_{6}$ double perovskite single crystals: Parity forbidden transitions and their application for sensitive and fast UV photodetectors. ACS Photonics 2018, 5, 398-405. [CrossRef]

128. Arfin, H.; Kaur, J.; Sheikh, T.; Chakraborty, S.; Nag, A. Bi ${ }^{3+}-\mathrm{Er}^{3+}$ and $\mathrm{Bi}^{3+}-\mathrm{Yb}^{3+}$ Codoped $\mathrm{Cs}_{2} \mathrm{AgInCl}_{6}$ Double Perovskite Near Infrared Emitters. Angew. Chem. Int. Ed. Engl. 2020, 59, 11307-11311. [CrossRef]

129. Vargas, B.; Ramos, E.; Pérez-Gutiérrez, E.; Alonso, J.C.; Solis-Ibarra, D. A Direct Bandgap Copper-Antimony Halide Perovskite. J. Am. Chem. Soc. 2017, 139, 9116-9119. [CrossRef]

130. Zhou, J.; Rong, X.; Molokeev, M.S.; Zhang, X.; Xia, Z. Exploring the transposition effects on the electronic and optical properties of $\mathrm{Cs}_{2} \mathrm{AgSbCl}_{6}$ via a combined computational-experimental approach. J. Mater. Chem. A 2018, 6, 2346-2352. [CrossRef]

131. Filip, M.R.; Liu, X.; Miglio, A.; Hautier, G.; Giustino, F. Phase diagrams and stability of lead-free halide double perovskites Cs2BB' $\mathrm{X} 6$ : $\mathrm{B}=\mathrm{Sb}$ and $\mathrm{Bi}, \mathrm{B}^{\prime}=\mathrm{Cu}, \mathrm{Ag}$, and $\mathrm{Au}$, and $\mathrm{X}=\mathrm{Cl}, \mathrm{Br}$, and I. J. Phys. Chem. C 2018, 122, 158-170. [CrossRef]

132. Deng, W.; Deng, Z.-Y.; He, J.; Wang, M.; Chen, Z.-X.; Wei, S.-H.; Feng, H.-J. Synthesis of $\mathrm{Cs}_{2} \mathrm{AgSbCl}_{6}$ and improved optoelectronic properties of $\mathrm{Cs}_{2} \mathrm{AgSbCl}_{6} / \mathrm{TiO}_{2}$ heterostructure driven by the interface effect for lead-free double perovskites solar cells. Appl. Phys. Lett. 2017, 111, 151602. [CrossRef]

133. Kieslich, G.; Sun, S.; Cheetham, A.K. Solid-state principles applied to organic-inorganic perovskites: New tricks for an old dog. Chem. Sci. 2014, 5, 4712-4715. [CrossRef]

134. Kieslich, G.; Sun, S.; Cheetham, A.K. An extended tolerance factor approach for organic-inorganic perovskites. Chem. Sci. 2015, 6, 3430-3433. [CrossRef]

135. Brown, I. The crystal structure of K2TeBr6. Can. J. Chem. 1964, 42, 2758-2767. [CrossRef]

136. Maughan, A.E.; Ganose, A.M.; Bordelon, M.M.; Miller, E.M.; Scanlon, D.O.; Neilson, J.R. Defect tolerance to intolerance in the vacancy-ordered double perovskite semiconductors $\mathrm{Cs}_{2} \mathrm{SnI}_{6}$ and $\mathrm{Cs}_{2} \mathrm{TeI}_{6}$. J. Am. Chem. Soc. 2016, 138, 8453-8464. [CrossRef]

137. Lee, B.; Stoumpos, C.C.; Zhou, N.; Hao, F.; Malliakas, C.; Yeh, C.-Y.; Marks, T.J.; Kanatzidis, M.G.; Chang, R.P. Air-stable molecular semiconducting iodosalts for solar cell applications: $\mathrm{Cs}_{2} \mathrm{SnI}_{6}$ as a hole conductor. J. Am. Chem. Soc. 2014, 136, 15379-15385. [CrossRef] [PubMed]

138. Debbichi, L.; Lee, S.; Cho, H.; Rappe, A.M.; Hong, K.H.; Jang, M.S.; Kim, H. Mixed Valence Perovskite Cs2Au2I6: A Potential Material for Thin-Film Pb-Free Photovoltaic Cells with Ultrahigh Efficiency. Adv. Mater. 2018, 30, 1707001. [CrossRef] [PubMed]

139. Ju, M.-G.; Chen, M.; Zhou, Y.; Garces, H.F.; Dai, J.; Ma, L.; Padture, N.P.; Zeng, X.C. Earth-abundant nontoxic titanium (IV)-based vacancy-ordered double perovskite halides with tunable 1.0 to $1.8 \mathrm{eV}$ bandgaps for photovoltaic applications. ACS Energy Lett. 2018, 3, 297-304. [CrossRef]

140. Sakai, N.; Haghighirad, A.A.; Filip, M.R.; Nayak, P.K.; Nayak, S.; Ramadan, A.; Wang, Z.; Giustino, F.; Snaith, H.J. Solutionprocessed cesium hexabromopalladate (IV), $\mathrm{Cs}_{2} \mathrm{PdBr}_{6}$, for optoelectronic applications. J. Am. Chem. Soc. 2017, 139, 6030-6033. [CrossRef] [PubMed]

141. Kong, D.; Cheng, D.; Wang, X.; Zhang, K.; Wang, H.; Liu, K.; Li, H.; Sheng, X.; Yin, L. Solution processed lead-free cesium titanium halide perovskites and their structural, thermal and optical characteristics. J. Mater. Chem. C 2020. [CrossRef]

142. Prasanna, R.; Gold-Parker, A.; Leijtens, T.; Conings, B.; Babayigit, A.; Boyen, H.-G.; Toney, M.F.; McGehee, M.D. Band gap tuning via lattice contraction and octahedral tilting in perovskite materials for photovoltaics. J. Am. Chem. Soc. 2017, 139, 11117-11124. [CrossRef] 